\title{
The application of micro-fish in clinical cytogenetics
}

Citation for published version (APA):

Engelen, J. J. M. (1998). The application of micro-fish in clinical cytogenetics. [Doctoral Thesis, Maastricht University, Maastricht University]. Universiteit Maastricht. https://doi.org/10.26481/dis.19980320je

Document status and date:

Published: 01/01/1998

DOI:

10.26481/dis.19980320je

Document Version:

Publisher's PDF, also known as Version of record

\section{Please check the document version of this publication:}

- A submitted manuscript is the version of the article upon submission and before peer-review. There can be important differences between the submitted version and the official published version of record.

People interested in the research are advised to contact the author for the final version of the publication, or visit the DOI to the publisher's website.

- The final author version and the galley proof are versions of the publication after peer review.

- The final published version features the final layout of the paper including the volume, issue and page numbers.

Link to publication

\footnotetext{
General rights rights.

- You may freely distribute the URL identifying the publication in the public portal. please follow below link for the End User Agreement:

www.umlib.nl/taverne-license

Take down policy

If you believe that this document breaches copyright please contact us at:

repository@maastrichtuniversity.nl

providing details and we will investigate your claim.
}

Copyright and moral rights for the publications made accessible in the public portal are retained by the authors and/or other copyright owners and it is a condition of accessing publications that users recognise and abide by the legal requirements associated with these

- Users may download and print one copy of any publication from the public portal for the purpose of private study or research.

- You may not further distribute the material or use it for any profit-making activity or commercial gain

If the publication is distributed under the terms of Article $25 \mathrm{fa}$ of the Dutch Copyright Act, indicated by the "Taverne" license above, 
THE APPLICATION OF MICRO-FISH IN CLINICAL CYTOGENETICS 
E Engelen, J.J.M. ISBN 90-9011427-0

Produktie en druk: Datawyse/Universitaire Pers Maastricht 
THE APPLICATION OF MICRO-FISH IN CLINICAL CYTOGENETICS

\section{PROEFSCHRIFT}

ter verkrijging van de graad van doctor aan

de Universiteit Maastricht, op gezag van de Rector Magnificus, Prof. Dr. A. Nieuwenhuijzen Kruseman volgens het besluit van het College van Decanen,

in het openbaar te verdedigen

op vrijdag 20 maart 1998 om 12.00 uur

door

Johan Joseph Maria Engelen 


\section{Promotor:}

Prof. Dr. J.P.M. Geraedts

\section{Beoordelingscommissie:}

Prof. Dr. J.L.H. Evers (voorzitter)

Prof. Dr. J.-P. Fryns

Prof. Dr. A. Geurts van Kessel (Katholieke Universiteit Nijmegen)

Prof. Dr. P.L. Pearson (Universiteit Utrecht)

Prof. Dr. F.C.S. Ramaekers

Publication of this thesis was financially supported by:

* Stichting Klinische Genetica Zuid-Oost Nederland

* Applied Imaging International Ltd

* Carl Zeiss B.V.

* Paes Nederland B.V. 


\section{Contents}

Chapter 1

General introduction

\section{Chapter 2}

A simple and efficient method for microdissection and FISH.

\section{Chapter 3}

Marker chromosome identification by micro-FISH.

\section{Chapter 4}

Disclosure of five breakpoints in a complex chromosome rearrangement (CCR) by microdissection and FISH.

Chapter 5

Application of micro-FISH to delineate deletions.

\section{Chapter 6}

Characterization of a de novo unbalanced translocation (14q18q) using micro-FISH.

\section{Chapter 7}

Duplication of chromosome region 15q11-q13 in a patient with similarities to Prader-Willi syndrome confirmed by region-specific and band-specific FISH.

\section{Chapter 8}

General discussion and conclusion.

Summary

Samenvatting

Dankwoord

Curriculum Vitae 
Chapter 1

GENERAL INTRODUCTION 


\section{Chromosome banding}

Clinical cytogenctics is the field of research that studies chromosomes at the microscopic level, with the aim to detect chromosome abnormalities and to explain their significance for the phenotype. Currently, Giemsa banding is the most widely used chromosome identification technique. It involves trypsin treatment of metaphase chromosome preparations followed by staining with Giemsa. This results in a pattern of light and dark bands that is unique for each chromosome. With this technique, 350550 bands for a haploid set of human chromosomes can be observed. This means that one band represents on average approximately $5-10 \times 10^{6} \mathrm{bp}$ of DNA. Examination of chromosomes in prometaphase, at which stage the chromosomes are less condensed than in metaphase, allows even higher degrees of resolution. Not less than 850 bands or even more than 1000 bands per haploid set of human chromosomes can be obtained in prometaphase.

\section{Chromosome abnormalities}

Chromosome abnormalities may be numerical or structural. Numerical chromosome abnormalities involve the gain or loss of one or more chromosomes (aneuploidy) and sometimes the gain of a complete set of chromosomes (polyploidy). Structural chromosome abnormalities may involve one or more chromosomes. When only one chromosome is involved, a part of the chromosome may be lost (deletion) or may be present twice (duplication). Furthermore, a part of one chromosome can be inverted with the centromere involved (pericentric) or not involved (paracentric) in the inversion. Structural abnormalities involving two or more chromosomes may result in insertion(s) of material of one chromosome into another, or translocation(s) of chromosomal material between two or more chromosomes. Individuals carrying a balanced translocation (either reciprocal or Robertsonian) are genetically and clinically normal if no chromosomal material is lost and no genes are damaged by the breakage of the chromosomes. However, such individuals are at increased risk of having chromosomally unbalanced offspring.

\section{In situ hybridization}

During the last fifteen years in situ hybridization (ISH) has been introduced as a diagnostic tool in clinical cytogenetics. This technique, first described in 1969 by Gall and Pardue $e^{\prime}$, can give information about the presence and expression of specific nucleic acid sequences in dividing and non-dividing cells. For ISH, a DNA fragment referred to as a probe, is labeled with a reporter molecule. After hybridization with cellular DNA the probe hybridizes with homologues nucleic acid sequences and can be detected. The detection procedure depends upon the nature of the reporter molecule. In the past, radioactive labeled probes were detected by autoradiography. Nowadays the reporter molecules are immunochemically detected by an antibody coupled with a 
fluorochrome or the reporter molecule is a fluorochrome itself. For the analysis of chromosome aberrations with fluorescence in situ hybridization (FISH) four major groups of probes are at the moment available.

[1] Whole chromosome painting probes paint a chromosome more or less completely and can be used for the analysis of chromosome translocations and insertions.

[2] Chromosome specific repetitive sequence probes hybridize near the centromere and can be used to determine the copy number of a chromosome in a non-dividing cell or the centromere that is present in a Robertsonian translocation chromosome.

[3] Unique sequence probes are used to study specific aberrations like deletions and duplications or breakpoints in a translocation.

[4] Subtelomeric probes are localized close to the telomeres and are used to detect deletions or cryptic translocations.

Despite these technical advances there still are chromosome aberrations (like marker chromosomes and de novo unbalanced translocations) that cannot (easily) be identified. For the characterization of these aberrations micro-FISH has been developed.

\section{Micro-FISH}

Micro-FISH comprises the physical dissection of (GTG)-banded chromosomes using a dissection needle or a laser beam. This is followed by a degenerate oligonucleotide primed-polymerase chain reaction (DOP-PCR) to amplify the dissected DNA and by labeling of the PCR product obtained with a reporter molecule. Subsequently, the DOP-PCR product is annealed to metaphase spreads from normal subjects and hybridization detected using FISH. Nowadays, micro-FISH is used in clinical cytogenetics to identify marker chromosomes and unbalanced translocations and to untangle complex chromosome rearrangements. In tumor cytogenetics micro-FISH is also used to identify the content of double minutes and homogeneously staining regions. For molecular geneticists, microdissection of chromosome regions or bands and subsequent cloning is an important step towards the isolation of disease related genes.

In 1981 microdissection was first successfully used by Scalenge et al. ${ }^{2}$ for cloning genomic sequences from Drosophila salivary gland polytene chromosome bands. A glass needle was attached to a micromanipulator to cut chromosome segments from Section 3 of the Drosophila X-chromosome which were then placed in a microdrop of liquid paraffin for subsequent cloning under the microscope. From the dissected DNA, 80 phage clones were obtained which hybridized in situ to the chromosomal region of dissection.

\section{Microdissection and molecular genetics}

Microdissection and microcloning of mammalian chromosomes was successfully applied using mouse chromosomes in 1984 by Rohme et al. ${ }^{3}$ and human chromosomes in 1986 by Bates et al. ${ }^{4}$. Since no PCR technology was available at that time, a large 
number of chromosome fragments $(100-200)$ had to be dissected prior to microcloning ${ }^{3 \cdot 12}$. The number of clones obtained in these libraries was far from being sufficient to represent the complete dissected region. However, the clones could be used as starting points for chromosome walking and jumping to the genes of interest. The first application of this approach allowed the isolation of useful clones from the proximal half of mouse chromosome 17 by Rohme et al. ${ }^{3}$. Later the same group dissected 270 mouse chromosome segments and produced 212 microclones which served as molecular probes for isolating additional DNA sequences for fine structure analysis and mapping of the mouse $t$-complex region ${ }^{13}$.

For the microdissection of mammalian chromosomes; unstained chromosome preparations were used to avoid cloning problems associated with chromosome banding and staining procedures. As identification of unbanded chromosomes is difficult, somatic cell hybrids containing a single human chromosome were used ${ }^{10,12}$. The dissection of the short arm of human chromosome 2 by Bates et all. ${ }^{4}$ was based on the characteristic morphology of this chromosome, being the largest submetacentric chromosome. The average insert size in the microclones derived from chromosome 2 was small, viz. 380 bp., suggested to be due to the acid treatment during fixation which results in hydrolysis of the $\mathrm{DNA}^{14}$. Later, care has been taken to minimize acid damage and microclones with larger inserts (mean length $3.2 \mathrm{~kb}$.) were then obtained from a chromosome $7 \mathrm{q} 22$ q23 library ${ }^{15}$. Although successful, microdissection followed by bacterial microcloning has a number of drawbacks: many (100-200) chromosome fragments have to be dissected, unstained chromosome preparations are to be used and the resulting libraries do not completely represent the dissected region.

\section{PCR amplification of microdissected material}

In 1989, Lüdecke et al. ${ }^{16}$ described an improved procedure for microcloning. Trypsinbanded and Giemsa stained chromosome preparations were used to collect a smaller number of chromosome fragments (20-30) which were amplified using the PCR technique. This enabled the construction of large libraries containing tens of thousands of microclones. In this procedure, the dissected fragments were collected in a microdrop containing proteinase $\mathrm{K}$ and the DNA was extracted from this drop with phenol. The purified DNA was cleaved with Rsal, blunt-ligated to a SmaI-cut pUC vector and cleaved again with Smal. After amplification by PCR the amplified sequences were cloned into pUC13. Using this procedure, the dissection of only 37 fragments resulted in a chromosome 8q23-q24 library which contained 20.000 microclones. The microdissection procedure was further improved by Senger et al. ${ }^{17}$. Libraries constructed this way were used to study region 15q11-q13 in Prader-Willi and Angelman syndrome ${ }^{18}$, region $\mathrm{Xq} 27-\mathrm{q} 28$ in fragile-X syndrome ${ }^{19}$, region $11 \mathrm{p} 13$ in Wilms tumor/aniridia ${ }^{20}$, region $22 q 12-q 13$ in neurofibromatosis ${ }^{21}$, region $5 q 21-q 22$ in adenomatous polyposis $\mathrm{coli}^{22,23}$ and region $8 \mathrm{q} 23-\mathrm{q} 24$ in Langer-Giedeon syndrome ${ }^{24}$. To construct these libraries, generally $20-40$ fragments were dissected and the resulting libraries contained $5,000-25,000$ microclones. The average insert size ranged from 150 to 220 bp and single copy microclones represented $39-80 \%$ of the library. Most of 
the clones isolated from the libraries were positive after hybridization to human DNA, and nearly all human-derived clones $(>90 \%)$ were shown to originate from the dissected region ${ }^{25}$. In another PCR-mediated microcloning procedure, described by Kao and $\mathrm{Yu}^{26}$, sticky-end ligation of the dissected sequences to a linker-adaptor is used and followed by PCR amplification using the adaptor sequence as primer. This procedure has been applied to human chromosomes and a very large library for human chromosome 21 was constructed which contained 700000 recombinant clones. The initial steps of this procedure were performed in nanoliter volumes under the microscope. First, proteins in the microdissected fragments were digested with proteinase- $K$, next DNA was extracted with phenol and cleaved with Mbol. Subsequently, the DNA fragments were ligated to a Mbol linker-adaptor and the sample was transferred to an Eppendorf tube for PCR using the 20-nt sequence of the adaptor as a primer. The PCR products were cleaved with Mbol, purified to remove adaptor molecules, cloned into pUC19, and transferred into a bacterial host. Using this procedure, a whole chromosome 21 library has been constructed from 30 dissected chromosome fragments. Thus isolation of genes was facilitated not only for Down syndrome, but also for other disorders linked to various regions of this chromosome, like Alzheimer disease, one form of epilepsy, and mental retardation ${ }^{27}$.

\section{Microdissection and clinical cytogenetics}

In 1992, Meltzer et al. ${ }^{29}$ introduced a novel procedure, termed micro-FISH, for the rapid generation of region-specific genomic clones from dissected chromosomal material using degenerate oligonucleotide primed PCR (DOP-PCR). DOP-PCR was developed by Telenius et al. ${ }^{28}$; it consists of a PCR using a 22 bp oligonucleotide with six degenerate bases close to the $3^{\prime}$ end (5'-CCGACTCGAGNNNNNNATGTGG-3') to generate whole chromosome paints from flow sorted chromosomes. Degenerate oligonucleotide primers allow the direct amplification of dissected DNA by priming at sites present in the genomic sequence. DOP-PCR eliminated the need for microchemical manipulations prior to PCR, because known sequences no longer had to be ligated to the microdissected material. The amplification procedure for the dissected sequences is simple in operation. The dissected fragments are transferred directly into a tube and treated with proteinase-K. Then the DNA is amplified in a first: DOP-PCR reaction and biotin labeled in a second PCR reaction. The PCR products thus generated appear to be useful for chromosome painting to aid in cytogenetic analysis. Guan et al ${ }^{30}$ further improved the micro-FISH technique and introduced the use of topoisomerase instead of proteinase-K to unwind the supercoiled DNA of the dissected fragments. Furthermore, T7 DNA polymerase (Sequenase) was used in the first 8 cycles of the DOP-PCR amplification, when the annealing temperature was low. T7 DNA polymerase was chosen for this step because it functions well at the low temperatures at which the random priming complexes are stable and because it possesses strand displacement synthesis capabilities. Strand displacement synthesis enables the enzyme to synthesize long stretches of DNA by displacing other primers that have already annealed to the DNA (Bohlander et al. ${ }^{3 \prime}$ ). These methodological 
improvements enabled synthesis of sufficient $P C R$ product for chromosome painting from only a single dissected chromosome ${ }^{30}$. Sequenase however, is heat inactivated at the denaturation temperature of $94^{\circ} \mathrm{C}$ and subsequently active Sequenase has to be added 8 times. Consequently, these steps are a prime target for contamination.

Fig. 1: Schematic representation of the micro-FISH procedure

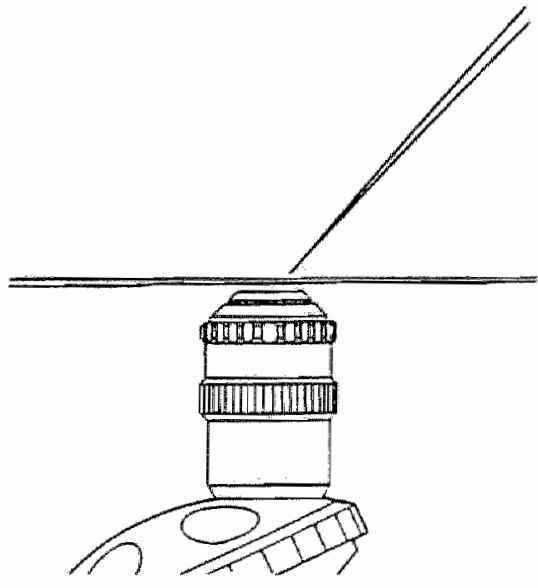

1. Dissection of a GTG-banded chromosome or chromosome part out of a metaphase with microneedles using an inverted microscope.

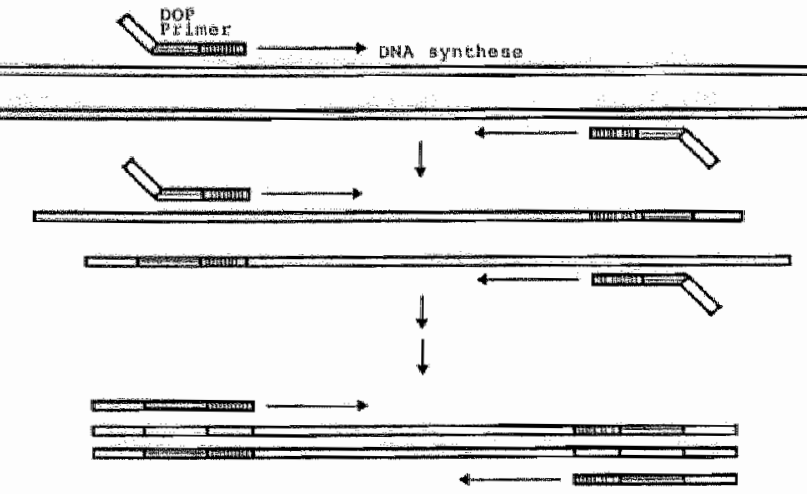

2. Amplification of the dissected material with a degenerate oligonucleotide primedpolymerase chain reaction (DOP PCR). 
3. Labeling of the generated DNA with a reporter molecule.
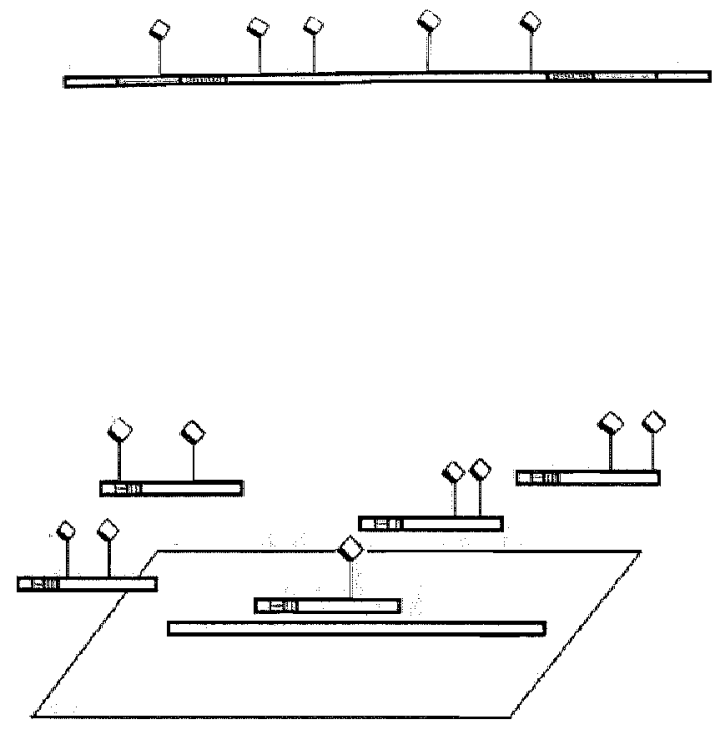

4. Hybridization of the probe on normal metaphase chromosomes or chromosomes of the patient.

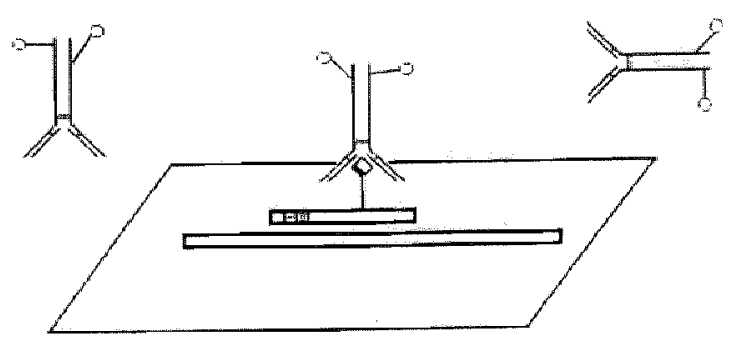

5. Immunochemical detection of the reporter molecule followed by microscopic and photografic analysis. 


\section{Clinieal applications}

In clinical cytogenetics micro-FISH has been successfully used to identify unbalanced chromosome translocations, marker chromosomes and complex chromosome rearrangements. Viersbach et al. ${ }^{32}$ used micro-FISH to characterize a marker in a boy with a $46, \mathrm{X},+$ mar karyotype and demonstrated that the marker was a $\mathrm{X} / \mathrm{Y}$ translocation chromosome. Furthermore, they dissected two marker chromosomes in a child with a $48, \mathrm{XY},+$ mar $1,+$ mar 2 karyotype. Reverse chromosome painting revealed that the centromeres of the chromosomes 13 and 21 displayed fluorescent signals; that these chromosomes were represented in the markers was confirmed by FISH using a repetitive DNA probe specific for the centromeres of chromosomes 13 and 21 , which gave positive signals on both marker chromosomes. A phenomenon always seen when micro-FISH includes the short arm of an acrocentric chromosome is that the short arms of (most of) the acrocentric chromosomes display fluorescent signals after reverse painting with the DOP-PCR product. This cross-hybridization was first reported by Viersbach et al. ${ }^{32}$ and later confirmed by Sun et al..$^{33}$ who characterized a marker derived from chromosome 21 . We had the same experience in our own experiments as illustrated in fig. 2 . Highly repetitive $B$ satellite DNA present in the short arm of the acrocentric chromosomes might be responsible for this cross-hybridization (Waye and Willard ${ }^{34}$ ).

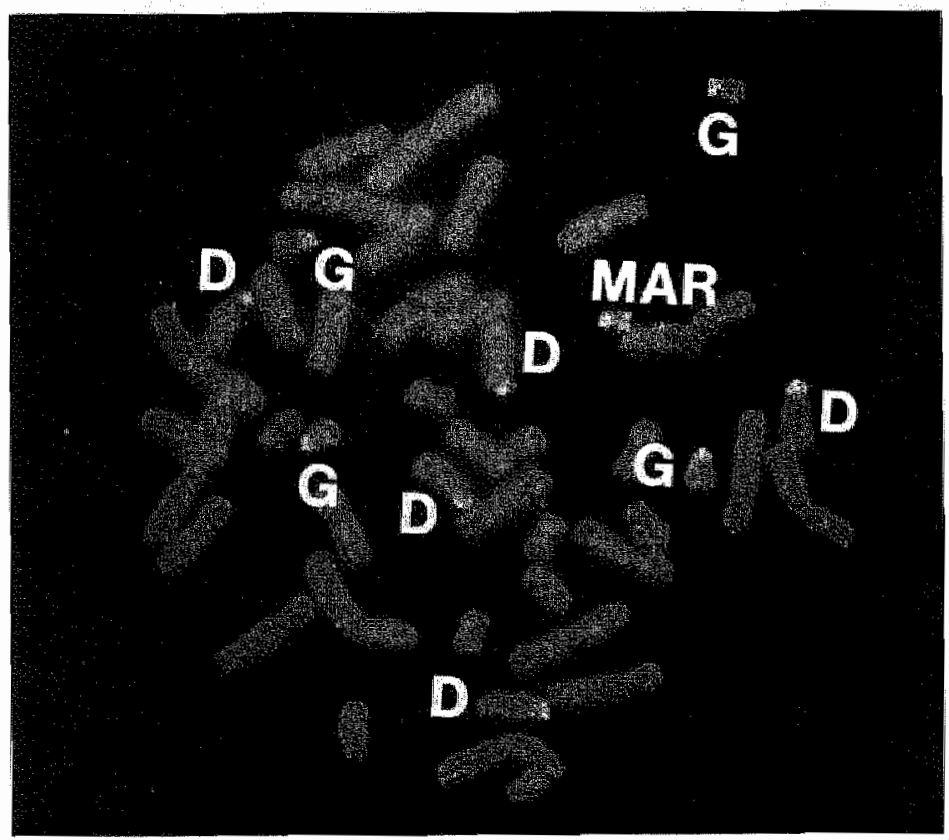

Fig. 2: Reverse painting with DOP-PCR material derived from an isochromosome $22 p$ showing cross-hybridization with most of the acrocentric chromosomes. D: chromosomes 13-15. G: chromosomes 21 and 22 . 
Besides for the identification of marker chromosomes, micro-FISH is often used for the disclosure of unbalanced chromosome translocations. In the article where Meltzer et al. ${ }^{29}$. first described micro-FISH, the technique was applied on chromosomes of a patient with an unbalanced karyotype who appeared to have a partial trisomy of chromosome 21 . Guan et al. ${ }^{35}$ generated whole chromosome painting probes with a slightly modified method which they subsequently used to identify two complex chromosome rearrangements. Rubtsov et al. ${ }^{36}$ used micro-FISH to study a terminal deletion of chromosome $6 \mathrm{q}$ and, unexpectedly, the hybridization pattern on normal metaphase chromosomes revealed an interstitial deletion with breakpoints in $6 \mathrm{q} 25.1$ and $6 \mathrm{q} 27$ instead of a terminal deletion.

In prenatal diagnosis micro-FISH was successfully used by Thangavelu et al..$^{37}$ to characterize a marker chromosome derived from chromosome 14 and by Muller-Navia et al. ${ }^{38}$ who disclosed that three prenatally detected markers were derived from chromosome 3 (p12-cen), chromosome 9 (p12-cen) and chromosome 18 (pter-cen) respectively. Muller-Navia et al. ${ }^{38}$ reported that the whole procedure of dissection, the amplification of the dissected chromosomal material and the labeling of the probe obtained with subsequent FISH could be completed within 72 hours.

\section{Microdissection and tumor cytogenetics}

Chromosome rearrangements in leukemic cell populations were studied using microFISH by Zhang et al. ${ }^{39}$ who demonstrated the translocation of ABL to BCR in both classic $\mathrm{Ph}^{+} \mathrm{CML}$ patients as well as in patients with variant translocations using bandspecific probes generated by chromosome microdissection. Deletion of part of the long arm of chromosome 6 , one of the most common chromosomal alterations in human Bcell lymphomas was studied by Guan et all. ${ }^{40}$. After the complete dissection of the aberrant chromosome 6, this chromosome was amplified with DOP-PCR and normal metaphases were reverse painted with the probe obtained. They found that the proximal breakpoint was $6 q 11$ in seven of nine cases, with the minimal region of deletion encompassing $6 \mathrm{q} 11$ to $6 \mathrm{q} 21$. They concluded that, by analogy to other tumor systems, the recurring breakpoints within $6 \mathrm{q} 11$ might suggest that a gene important to the genesis or progression of follicular lymphoma could be localized to this band. In tumor cytogenetics micro-FISH is a valuable tool to detect oncogenes amplified in homogeneously staining regions (HSRs) and in double minutes (DMs), as structures like DMs and HSRs can originate from multiple chromosome sites (Guan et al. ${ }^{41}$, Su et al. ${ }^{42}$. Ray et al. ${ }^{43}$ and Guan et al. ${ }^{44}$ ).

Dissection of 16 HSRs (Guan et al. ${ }^{41}$ ) from nine breast cancer cell lines showed that the most commonly amplified chromosomal band was $17 q 12$ (containing ERBB2). However, regions not containing known oncogenes were also identified, including $13 q 31$ and $20 \mathrm{q} 12-\mathrm{q} 13.2$. Su et all. ${ }^{42}$ have isolated 2 genes from a HSR dissected from an osteosarcoma cell line and mapped these genes to $12 q 13-q 15$. In micro-FISH studies of malignant melanoma multiple overexpressed copies of the IGF1R gene were shown to be present in a HSR-bearing cell line (Guan et al. ${ }^{45}$, Zhang et al. ${ }^{46}$ and Zhang et al. $\left.^{4 \pi}\right)$. 
Another technique now widely used to ascertain which chromosome regions are altered in a malignancy is comparative genomic hybridization (CGH). Colocalization of DNA from tumor and normal cells by dual fluorescent hybridization to normal metaphases generates a profile which identifies regions that are amplified or deleted in the tumor cells. To determine the sensitivity of microdissection in conjunction with CGH Joos et al ${ }^{* 8}$ dissected variable numbers of cells from the cell line Colo 320 . They report that $40 \%-50 \%$ of the imbalances present in the cell line were detected. However, when less than ten nuclei were dissected a high proportion of additional imbalances was found constituting false-positive results. Fujii et al.$^{49}$ used microdissection to isolate infiltrating breast cancer tumor cells from contaminating normal lymphocytes and stromal cells. When analysing microsatellite repeats from chromosome region $6 \mathrm{q} 23->\mathrm{q} 25.2$ they detected a much higher frequency of allelic loss in this chromosome region than had been previously detected in breast cancer. Although micro-FISH is the most direct way to generate region- and band-specific paints and thus to characterize chromosome abnormalities, another method seems to be equally effective for this purpose. This method, described by Jinno et al. ${ }^{50}$, still includes a microchemistry step where microdissected chromosomes are digested with Sau3AI. The chromosome fragments are then ligated to synthesized oligonucleotides using T4 ligase and amplified by PCR. A small part of the PCR product is used then as a FISH probe, the remaining PCR product is usually used for cloning. Deng et al. ${ }^{51}$ and Ohta et al. ${ }^{52}$ used this method to characterize unbalanced chromosome translocations, Ohta et al ${ }^{52}$ and de Albuquerque-Coelho et al.$^{53}$ disclosed the chromosomal origin of marker chromosomes and Sen et al. ${ }^{54}$ determined the chromosomal content of double minutes.

\section{Quality of the micro-FISH products}

For the successful application of micro-FISH certain precautions have to be made. DNA damage due to methanol:acetic acid treatment during fixation should be reduced. Depurination of the chromosomal DNA (Mezzanotte et al. ${ }^{14}$ ) can in part be prevented by using a 9:1 methanol:acetic acid fixation instead of the 3:1 standard formula (Hagag et al. ${ }^{55}$ ). Furthermore, when cover glass slides holding the metaphases are made, these slides should be washed immediately with distilled water to remove remaining acetic acid. Subsequently, slides should be stored in $95 \%$ ethanol at $-20{ }^{\circ} \mathrm{C}$ until use, and when used for microdissection, a slide should not be used for more than one hour (Hagag et al..$^{55}$ ). The most important factor for the quality of the DOP-PCR product after microdissection of an eventually constructed library is the effective prevention of contaminant DNA during the microdissection and microcloning steps. Thus, stringent procedures to minimize contamination should be adopted (Kao et al ${ }^{26}$ ). These include: (1) Use of only disposable pipettips, eppendorf tubes, etc; (2) Wearing gloves during all steps of the procedure; (3) Preparing all buffers and reagents in an air-clean hood; (4) Exposing the dissecting needles, micropipets and all buffers and reagents to ultraviolet light ( $254 \mathrm{~nm}$ ); (5) Including a control in each experiment treated identical as the dissected sample. If any detectable background PCR product is 
found in the control, indicating contamination, the experiment should be discarded. The quality of the DOP-PCR product can be monitored by examining the PCR products after gel electroforesis and ethidium bromide staining; (6) If the DOP-PCR product is used for microcloning, part of the product should be hybridized in situ to metaphase chromosomes to make sure that only the dissected region displays a FISH signal.

\section{Applications of microdissection and micro-FISH in (human) genome analysis}

1. Synthesis of region- and band-specific (DOP)-PCR products which can be used in clinical cytogenetics as FISH probes for reverse painting to analyze marker chromosomes, deletions, unbalanced translocations, complex chromosome rearrangements, and other structural chromosomal abnormalities involving the dissected region ${ }^{(29-33,35-38,56)}$.

2. Synthesis of region- and band-specific (DOP)-PCR products to analyse chromosome aberrations (frequently) occurring in patients with leukaemia ${ }^{(39,40,57,588}$.

3. Synthesis of region- and band-specific (DOP)-PCR products to analyse chromosome aberrations occurring in solid tumors e.g. double minutes, homogeneously staining regions and the chromosome aberrations mentioned before ${ }^{(41-47,59)}$.

4. Isolation of sequences from translocation breakpoints and from small deletions associated with genetic diseases or specific forms of cancer ${ }^{\{39,44,60\}}$.

5. Construction of region- or band-specific libraries. From these libraries large numbers of unique sequence microclones can be isolated for molecular genetic and genome studies ${ }^{(18-24,42-47)}$.

6. The unique clones are valuable for the isolation of YAC clones for contig assembly and for physical mapping and saturation cloning of the dissected region ${ }^{60}$. Furthermore, these clones can be used to isolate candidate genes from cDNA clones to facilitate cloning of disease-related genes ${ }^{(61-64)}$.

7. Analysis of the molecular structure and organization of specific chromosome landmarks such as centromeres, telomeres, heterochromatin, acrocentric short arms, fragile sites, etc. ${ }^{(19,65,66)}$.

8. Construction of chromosome region- or band-specific genomic libraries from other than human species, for molecular genetic studies in these species and for comparative studies between species ${ }^{(2,3,5,6,8,8,9,11,13,67-70)}$.

9. Microdissection (followed by DOP-PCR) of single cells, specially tumor cells, which can be studied (using $\mathrm{CGH}$ ) without background contamination from any other cellular or tissue constituents ${ }^{(48,49)}$. 


\section{AIVS OF THIS THESIS}

This study was initiated to contribute to the further development of micro-FISH as well as to applicate this technique in routine clinical cytogenetics. The aims of this study were:

1. To develop a fast, reliable and efficient method for microdissection and microFISH.

2. To use micro-FISH for the characterization of marker chromosomes that could not (easily) be identified using conventional cytogenetic techniques.

3. To study complex chromosome rearrangements and detect and identify losses and gains of chromosomal material.

4. To study the sensitivity of the developed procedure in detecting loss of chromosomal material. 


\section{References}

1- Gall G, Pardue ML: Formation and detection of RNA-DNA hybrid molecules in cytologic preparations. Proc Natl Acad Sci USA 63:378-381 (1969).

2- Scalenghe $\mathrm{R}$, Turco $\mathrm{E}_{3}$ Edstrom JE, Pirtotta $V$, Melli M: Microdissection and cloning of DNA from a specific region of Drosophila melanogaster polytene chromosomes. Chromosoma 84:205-216 (1981).

3- Rohme D, Fox H, Hermann B, Frischauf AM, Edstrom JE, Mains P, Silver LM, Lehrach H: Molecular clones of the mouse t-complex derived from microdissected metaphase chromosomes. Cell $36: 783-788$ (1984).

4- Bates GP, Wainwricht BJ, Williamson R, Brown SDM: Microdissection of and microcloning from the short arm of human chromosome 2. Mol Cell Biol 6:3826-3830 (1986).

5- Fisher EMC, Cavanna JS, Brown SDM: Microdissection and microcloning of the mouse X chromosome. Proc Natl Acad Sci USA 82:5846-5849 (1985).

6- Greenfield AJ, Brown SDM: Microdissection and microcloning from the proximal region of mouse chromosome 7: Isolation of clones genetically linked to the Pudgy locus. Genomics 1:153-158 (1987).

7- Kaiser R, Weber J, Grzeschik KH, Edstrom JE, Driesel A, Zengerling S, Buchwald M, Tsui LC, Olek K: Microdissection and microcloning of the long arm of human chromosome 7. Mol Biol Report 12:3-6 (1987).

8- Weith $A$, Winking $H$, Brackmann $B$, Boldyreff $B$, Traut $W$ : Microclones from a mouse germ line HSR detect amplification and complex rearrangements of DNA sequences. EMBO J 6: 1295-1300 (1987).

9- Brockdorff N, Fisher EMC, Carwanna JS, Lyon MF, Brown SDM: Construction of a detailed molecular map of the mouse $\mathrm{X}$ chromosome by microcloning and interspecific crosses. EMBO J 6:3291-3297 (1987).

10-Weber J, Weith A, Kaiser R, Grzeschik KH, Olek K: Microdissection and microcioning of human chromosome 7q22-32 region. Somat Cell Mol Genet 16:123-128 (1990).

11-Tonjes RR, Weith A, Rinchik EM, Winking H, Carnwath JW, Kaliner B, Paul D: Microclones. derived from the mouse chromosome $7 \mathrm{D}-\mathrm{E}$ band map within the proximal region of the $\mathrm{C}^{14 \cos }$ deletion in albino mutant mice. Genomics 10:686-691 (1991).

12-Kao FT: Microdissection and microcloning of human chromosome 21. In Molecular Genetics of Chromosome 21 and Down Syndrome, (D. Patterson and C.J. Epstein, Eds) pp. 89-104 Wiley-Liss, New York (1990).

13-Hermann B, Bucan M, Mains PE, Frischauf AM, Silver LM, Lehrach H: Genetic analysis of the proximal portion of the mouse t-complex: Evidence for a second inversion within thaplotypes. Cell 44:469-476 (1986).

14-Mezzanotte R, Vanni R, Flore O, Ferruci L, Sumner AT: Aging of fixed cytological preparations produces degradation of chromosomal DNA. Cytogenet Cell Genet 48:60-62 (1988).

15-Brown SDM, Greenfield AJ: A model to describe the size distribution of mammalian genomic. fragments recovered by microcloning. Gene 55:327-332 (1987).

16-Ludecke $H J$, Senger $G_{1}$ Claussen $U$, Horsthemke $B$ : Cloning defined regions of the human genome by microdissection of banded chromosomes and enzymatic amplification. Nature 338:348$350(1989)$.

17-Senger $\mathrm{G}$, Lüdecke $\mathrm{HJ}_{\mathrm{y}}$ Horsthemke $\mathrm{B}$, Claussen $\mathrm{U}$ : Microdissection of banded human chronosomes. Hum Genet 84:507-511 (1990).

18-Buiting $K_{*}$ Neumann M, Ludecke $\mathbb{H J}$, Senger G, Claussen U, Antich J, Passarge Ex Horsthemke B: Microdissection of the Prader-Willi syndrome chromosome region and identification of potential gene sequences. Genomics 6:521-527 (1990).

19-MacKinnon RN, Hirst MC, Bell MV, Watson JEV, Claussen U, Lüdecke HJ, Senger G, Horsthemke B, Davies KE: Microdissection of the fragile X region. Am J Hum Genet 47:181-187 (1990).

20-Davis LM, Senger G, Lüdecke HJ, Claussen U, Horsthemke B. Zhang S, Metzroth B, 
Hoherfelner $\mathrm{K}, \mathrm{Zabel} B$, Shows TB: Somatic cell hybrid and long-range physical mapping of $11 \mathrm{p} 13$ microdissected genomic ciones. Proc Natl Acad Sci USA 87:7005-7009 (1990).

21-Fiedler W, Claussen U, Ludecke HJ, Senger G, Horsthemke B, Geurts van Kessel A, Goertzen W, Fahsold R: Now markers for the neurofibromatosis- 2 region generated by microdissection of chromosone 22. Genomics 10:786-791 (1991).

22. Hampton $G_{3}$ Leuteritz $G$, Ludecke HJ, Senger $G_{\text {, Traumann }}$, Thomas $H$, Solomon $E$, Bodmer WF, Horsthemke $B$, Claussen $U$, Ballhausen WG: Characterization and mapping of microdissection. genomic claries from the adenomatous polyposis coli (APC) region. Genomics 11:247-251 (1991). 23-Hampton GM, Howe C. Leuteritz G, Thomas H, Bodmer WF, Solomon E, Ballhausen WG: Regional mapping of 22 microclones around the adenomatous polyposis coli (APC) locus on chromosome $5 \mathrm{q}$. Hum Genet 88:112-114 (1991).

24-Ludecke HJ, Johnson C, Wagner MJ, Wells DE, Turleau C, Tommerup N, Lator-Bielenska A, Sandig KR, Meinecke P, Zable B, Horsthemke B: Molecular definition of the shortest region of deletion overlap in the Langer-Giedion syndrome. Am J Hum Genet 49:1197-1206 (1991).

25-Ludecke HJ, Senger G, Claussen U, Horsthemke B: Construction and characterization of bandspecific DNA libraries. Hum Genet 84:512-51 (1990).

26-Kao Fr, Yu JW: Chromosome microdissection and cloning in human genome and genetic disease analysis. Proc Natl Acad Sci USA 88:1844-1848 (1991)

27-Yu J, Hartz J, Xu Y, Gemmill RM, Korenberg JR, Patterson D, Kao FT: Isolation, characterization and regional mapping of microclones from a human chromosome 21 microdissection library. Am J Hum Gienet $51: 263-272$ (1992).

28-Telenius $H_{3}$ Carter NP, Bebb CE, Nordenskjold M, Ponder BA, Tunnacliffe A: Degenerate oligonucleotide-primed PCR: general amplification of target DNA by a single degenerate primer. Genomics 13:718-725 (1992).

29-Meltzer PS, Guan XY, Burgess A, Trent JM: Rapid generation of region specific probes by chromosone microdissection and their application. Nature Genet 1:24-28 (1992).

30-Guan XY, Trent JM, Meltzer PS: Generation of band-specific painting probes from a single microdissected chromosome. Hum Mol Genet 8:1117-1121 (1993).

31-Bohlander SK, Espinosa III R, Le Beau ML, Rowley JD, Diaz MO: A method for the rapid sequence-independent amplification of microdissected chromosomal material. Genomics 13: 1322 1324 (1992).

32-Viersbach $R$, Schwanitz $G$, Nothen $M$. Delineation of marker chromosomes by reverse chromosome painting using only a small number of DOP-PCR amplified microdissected chromosomes. Hum Genet 93:663-667 (1994).

33-Sun $\mathrm{Y}$, Rubinstein J, Soukop $\mathrm{S}_{\mathrm{y}}$ Palmer CG. Marker chromosome 21 identified by microdissection and FISH. Am J Med Genet 56:151-54 (1995).

34-Waye J, Willard HF. Human B satel lite DNA: Genomic organization and sequence definition of a class of highly repetitive tandem DNA. Proc Natl Acad Sci USA 86:6250-6254 (1989).

35-Guan XY, Meltzer PS, Trent JM: Rapid generation of whole chromosome painting probes (WCPs) by chromosome microdissection. Genomies 22:101-107 (1994).

36-Rubtsov N, Senger G, Kuzcera H, Neumann A, Kelbova $C_{*}$ Junker K, Beensen V, Claussen U: Interstitial deletion of chromosome $6 \mathrm{~g}$ : precise definition of the breakpoints by microdissection, DNA amplification, and reverse painting. Hum Genet 97:705-709 (1996).

37-Thangavelu $\mathrm{M}_{\text {, Pergament }}$, Espinosa $\mathrm{R}$, Bohlander SK. Characterization of marker chromosomes by microdissection and fuorescence in situ hybridization. Prenat Diagn 14:583-588 (1994). 38. Muller-Navia I, Nebel A, Schleiermacher E: Complete and precise characterization of marker chromosomes by application of microdissection in prenatal diagnosis. Hum Genet 96:661-667 (1995).

39-Zhang J, Meltzer $\mathrm{P}$, Jenkins $\mathrm{R}$, Guan XY, Trent $\mathrm{J}$ : Application of chromosone microdissection probes for elucidation of $\mathrm{BCR}-\mathrm{ABL}$ fusion and variant Philadelphia chromosome translocations in chronic myelogenous leukemia. Blood 12:3365-3371 (1993).

40-Guan XY, Horsman D, Zhang HE, Parsa NZ, Meltzer PS, Trent JM: Localization by chromosome microdissection of a recurrent breakpoint region on chromosome 6 in human B-cell lymphoma.

Blood 88:1418-1422 (1996). 
41-Guar XY, Meltzer PS, Dalton WS, Trent JM: Identification of eryptic sites of DNA sequence amplification in human breast cancer by chromosome microdissection. Nahure Genet 8:155-161 (1994).

42-Su YA, Trent JM, Guan XY, Meltzer PS: Direet isolation of genes encoded within a homogeneously staining region by chromosome microdissection. Proc Nat Acad Sci USA 91:9121-9125 (1994).

43-Ray ME, Guan XY, Slovak ML, Trent JM, Meltzer PS: Rapid detection, cloning and molecular cytogenetic characterisation of sequences from an MPR-encoding amplicon by chromosome microdissection. Br. J. Cancer 70;85-90 (1994).

44-Guan XY, Cargille CB, Anzick SL, Thompson FH, Meltzer PS, Bittner ML, Taetle $R$, McGill JR, Trent JM: Chromosome microdissection identifies cryptic sites of DNA sequence amplification in human ovarian carcinoma. Cancer Res 55:3380-3385 (1995).

45-Guan XY, Meltzer PS, Cao J, Trent JM: Rapid generation of region-specific genomic clones by chromosome microdissection; isolation of DNA from a region frequently deleted in malignant melanoma. Genomics 14:680-684 (1992).

46-Zhang J, Trent JM, Meltzer PS: Rapid isolation and characterization of amplified DNA by chromosome microdissection: identification of IGFIR amplification in malignant melanoma. Oncogene 8:2827-283! (1993).

47-Zhang J, Cui P, Glatfelter A, Cummings LM, Meltzer PS, Trent JM: Microdissection based cloning of a translocation breakpoint in a human malignant melanoma. Cancer Research 55:46404645 (1995).

48-Joos $\mathrm{S}$, Ohl S, Lichter P: Analysis of chromosomal imbalances in very small populations by uniwersal PCR and comparative genomic hybridization. Cytogenet Cell Genet 77:1-2/W5 (1997).

49-Fujii $\mathrm{H}$, Zhou W, Gabrielson E; Detection of frequent allelic loss of $6 \mathrm{q} 23->\mathrm{q} 25.2$ in microdissected human breast cancer tissues. Genes Chrom Cancer 16:35-39 (1996).

50-Jinno Y, Harada N, Yoshiura KI, Ohta T, Tohma T, Hirota T, Tsukamoto K, Deng HX, Oshimura M, Niikawa N: A simple and efficient amplification method of DNA with unkwown sequences and its application to microdissection/microcloning. J Biochem 112:75-80 (1992).

51-Deng HX, Yoshiura KI, Dirks RW, Harada N, Hirota T, Tsukamoto K, Jinno Y, Niikawa N: Chromosome-band-specific painting: Chromosome in situ suppression hybridization using PCR products from a microdissected chromosome band as a probe pool. Hum Genet 89:13-17 (1992). 52-Ohta T, Tohma T, Soejima H, Fukushima Y, Nagai T, Yoshiura K, Jimno Y, Niikawa N. The origin of cytogenetically unidentifiable chromosome abnormalities: six cases ascertained by targeted chromosome-band painting. Hum Genet 92:1-5 (1993).

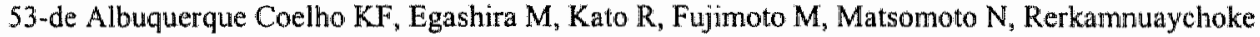
$B$, Abe $K$, Harada $N$, Ohashi $H$, Fukushima $Y$, Niikawa $N$ : Diagnosis of four chromosome abnormali. ties of unkwown origin by microdissection and subsequent reverse and forward painting. Am J Med Genet 63:468-471(1996).

54-Sen S, Sen P, Mulac-Jericevic B, Zhou H, Pirrotta V, Stass SA: Microdissected double-minute DNA detects variable patterns of chromosomal localizations and multiple abundantly expressed transcripts in normal and leukemic cells. Genomics 19:542-551 (1994).

55-Hagag NG, Viola MV: Chromosome microdissection and cloning, a practical guide. Academic press, Inc. $29-30$ (1993).

56-Yokoyama Y, Sakuragawa N: Improved simple generation of GTG-band specific painting probes. Cytogenet Cell Genet $71: 32-36$ (1995).

57-Cotler FE, Willington D, Hampton G, Riddle P, Nasipuri S, Gibbons B, Young BO: Gene

mapping by microdissection and breakpoints on chromosome 11. Genes Chromosom Cancer 3:8 15 (1991).

58-Ionveaux P, Le Coniat M, Derre J, Flexor MA, Daniel MT, Berger R: Chromosome

microdissection in leukemia: a powerful tool for the analysis of complex chromosomal rearrangements. Genes chromosom cancer 15:26-33 (1996).

59-Trautmann U, Leuteritz G, Senger G, Claussen U, Ballhausen WG: Detection of APC regionspecific signals by nonisotopic chromosomal in situ suppression (CISS)-hybridization using. microdissection library as a probe. Hum Genet 87:495-497 (1991). 
60-Hirota $T$, Tsukamoto $K$, Deng HX, Yoshiura KI, Ohta $T$, Tohma T, Kibe T, Harada N, Jinno $Y$, Nikawa N: Mierodissection of human chromosomal regions 8q23.3-q24.11 and $2 \mathrm{q} 33$-qter: construction of DNA libraries and isolation of theit clones. Genomics 13:349-354 (1992).

61-Bardenhewer W, Szymanski S, Lux A, Ludecke HI, Horsthemke B, Claussen U, Senger G, Smith DI, Wang ND, Lepaslier D, Cohen D, Heppel-Parton $A_{\text {, }}$ Rabbits P, Schutte J, Opalka B: Characterization of a microdissection library from human chromosome region 3p14. Genomics 19:291-297 (1994).

62-Djabali M, Nguyen C, Biunno I, Oostra BA, Mattei MG, Ikeda JE, Jordan BR: Laser microdissection of the fragile $X$ region: identification of cosmid clones and of conserved sequences of this region. Genomics 10:1053-1060 (1991).

63-Selci $N$, Yamauchi $M$, Saito $T$, Katakura R, Ohta $T$, Yoshiura KI, Jinno Y, Nikawa M, Hori TA: Microdissection and microcloning of genomic DNA markers from human chromosomal region 11q23. Genomics 16:169-172 (1993).

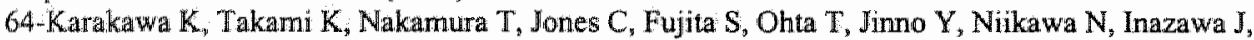
Ariyama T, Mori T, Takai $S$, Nishisho I: Isolation of region-specific cosmids by hybridization with microdissection clones from human chromosome $10 \mathrm{q} 11.1-\mathrm{q} 21.1$. Genomics 17:449-455 (1993). 65-MacKinnon RW, Hirst MC, Bell MV, Watson JEV, Claussen U, Lüdecke HJ, Senger G, Horsthemke B, Davies KE: Microdissection of the fragile-X region. Am J Hum Genet 47:181-187 (1990).

66-Johnson DH, Kroisel PM, Klapper HJ, Rosenkranz W: Microdissection of a human marker chromosome reveals its origin and a new family of centromeric repetitive DNA. Hum Molec Genet 1(9):741-747 (1992).

67-Vidal SM, Epstein DI, Malo D, Weith A, Vekeman M, Gros P: Identification and mapping of six microdissected genomic DNA probes to the proximal region of mouse chromosome 1. Genomics 14:32-377 (1992).

68-Bahary N, McGraw DE, Shilling R, Friedman IM: Microdissection and microcloning of mid chromosome 4: genetic mapping of 41 microdissection clones. Genomics 16:113-122 (1993). 69-Pich U, Houben A, Fuchs J, Meister A, Schubert I: Utility of DNA amplified by degenerate oligonucleotide-primed PCR (DOP-PCR) from the total genome and defined chromosomal regions of the field bean. Mol Gen Genet 243(2):173-177 (1994).

70-Xiao Y, Darroudi F, Kuipers AGJ, de Jong JH, de Boer P, Natarajan AT: Generation of mouse chromosome painting probes by DOP-PCR amplification of microdissected meiotic chromosomes. Cytogenet Cell Genet 75:63-66 (1996). 


\section{A SIMPLE AND EFFICIENT METHOD FOR MICRODISSECTION AND} FISH.

John J.M. Engelen, Jozefa C.M. Albrechts, Guus J.H. Hamers and Joep P.M. Geraedts.

Department of Molecular Cell Biology and Genetics, University of Maastricht, Maastricht, The Netherlands. 
We developed a simple and efficient method for the dissection of (marker) chromosomes, micronuclei and chromosome regions. Before microdissection, metaphases were overlaid with milli- $Q$ water to rehydrate the chromosomes which made them soft and sticky. The dissected chromosome fragments were dissolved without proteinase- $K$ or topoisomerase treatment and directly amplified using a degenerate oligonucleotide primed-polymerase chain reaction (DOP-PCR). The advantages of this method over previously reported methods are: microdissection in this way is very fast; a chromosome, marker, micronucleus or chromosome region is collected as a whole using only one microneedle; the dissected material sticks tightly to the needle without the risk of getting lost; no Sequenase is used in the DOP-PCR reaction which reduced the risk of contamination. 


\section{Introduction}

Microdissection is introduced in human cytogenetics by Bates et al." who constructed a library for chromosome 2 using many ( 100 or more) chromosome fragments that ware dissected from unbanded and unstained chromosomes . Liidecke et al. ${ }^{2}$ described an improved procedure for microdissection and microcloning and introduced the PCR technique to amplify the minute amounts of dissected chromosome fragments. This method was improved further by Senger et al. ${ }^{3}$ who successfully dissected single bands from GTG-banded chromosomes. Micro-FISH, a technique developed by Meltzer et al. ${ }^{4}$ represents at the moment the most straightforward method for the synthesis of chromosome region-specific and chromosome band-specific paints and thus for the characterization of chromosome aberrations. In this technique four important steps can be distinguished: (1) the physical dissection of (part of) a chromosome or a marker chromosome, (2) incubation of the dissected material with proteinase-K or topoisomerase to relax the supercoiled DNA of the metaphase chromosome(part)s, (3) degenerate oligonucleotide primed-polymerase chain reaction (DOP-PCR) to amplify the dissected material and (4) labeling of the PCR product with biotin or digoxigenin followed by fluorescence in situ hybridization with the probe obtained. In this study we describe an improved and simplified method for microdissection, dissolvement of the dissected material and DOP-PCR with less risk of contamination.

\section{Material and methods}

\section{Preparation of metaphase chromosomes}

Chromosomes were prepared from peripheral blood lymphocytes using the synchronization method of Dutrillaux and Viegas-Pequignot ${ }^{5}$ with only minor modifications. Chromosome spreads for microdissection were made according to routine procedures on $45 \times 65 \mathrm{~mm}$ coverslips. The slides were rinsed in distilled water and stored in $98 \%$ ethanol at $-20^{\circ} \mathrm{C}$. GTG-banding with trypsin-Giemsa was performed prior to microdissection.

\section{Microdissection of banded chromosomes}

Microdissection was performed with glass microneedles controlled by a Narishige micromanipulator (MO-202). To avoid contamination with extraneous DNA microneedles, microcentrifuge tubes (including the collection drop) and pipettips were treated with ultraviolet light for $30 \mathrm{~min}$. Before microdissection of a (marker) chromosome we looked for a metaphase with well spread chromosomes that was covered with $2 \mu 1$ milli-Q water. Due to the rehydration the chromosomes became sticky and could be collected as a whole using only one microneedle. To collect a chromosome band or region, a slightly different procedure was followed. The chromosome bands proximal and distal of the band or region of interest were dissected when the chromosomes were still dry; subsequently a new microneedle was installed, the metaphase was coverred with $2 \mu \mathrm{lmilli}-\mathrm{Q}$ water and the chromosome band or region was dissected. In the experiments five chromosome bands or regions were collected in this way with the 
chromosome (part) glued to the needle tip and transferred to a $20 \mu l$ collection drop (containing $2.5 \mathrm{mM} \mathrm{MgCl} 2,50 \mathrm{mM} \mathrm{KCl}, 10 \mathrm{mM}$ Tris- $\mathrm{HCl} \mathrm{pH} 8.3,0.1 \mathrm{mg} / \mathrm{ml}$ gelatine, $0.1 \%(\mathrm{v} / \mathrm{v}) \mathrm{Brij}-35$ (Sigma)) in a $0.5 \mathrm{ml}$ microcentrifuge tube. A fresh microneedle was used for each dissection.

\section{Amplification of ehromosomal DNA}

After sufficient chromosomal material was collected, the samples were cycled for 20 cycles of $30^{\circ} \mathrm{C}$ for $1 \mathrm{~min}$ and $50^{\circ} \mathrm{C}$ for $1 \mathrm{~min}$ to dissolve the dissected chromosome (part)s. Subsequently, $30 \mu \mathrm{l}$ PCR buffer containing $100 \mu \mathrm{M}$ of each dNTP, $2,5 \mathrm{mM}$ $\mathrm{MgCl} 2,50 \mathrm{mM} \mathrm{KCl}, 10 \mathrm{mM}$ Tris- $\mathrm{HCl} \mathrm{pH} \mathrm{8.3,5} \mathrm{ng}$ acetylated BSA, $4 \mu \mathrm{M}$ universal primer and $0.5 \mathrm{U}$ super Taq DNA polymerase (HT Biotechnology) was added to each sample. The universal primer $5^{\prime}$ CCGACTCGAGNNNNNNATGTGG 3 ' was used as suggested by Telenius et al.$^{6}$. For initial denaturation the mixture was heated to $93{ }^{\circ} \mathrm{C}$ for $3 \mathrm{~min}$, followed by 8 cycles of $1 \mathrm{~min}$ at $94^{\circ} \mathrm{C}, 1 \mathrm{~min}$ at $30^{\circ} \mathrm{C}, 1 \mathrm{~min}$ at $45^{\circ} \mathrm{C}$ and 3 min at $72{ }^{\circ} \mathrm{C}$ and by 28 cycles of $1 \mathrm{~min}$ at $94^{\circ} \mathrm{C}, 1 \mathrm{~min}$ at $56^{\circ} \mathrm{C}, 3 \mathrm{~min}$ at $72^{\circ} \mathrm{C}$ with a final extension step at $72^{\circ} \mathrm{C}$ for $10 \mathrm{~min}$. The DOP-PCR experiments always contained a negative control consisting of all PCR components except microdissected DNA and a positive control with $25 \mathrm{pg}$ total human DNA. PCR reactions were performed in a Biometra personal cycler with a heated lid. PCR products were stained with ethidium bromide and analysed for yield and probe size (200-900 base pairs) on an agarose gel. Experiments were proceeded only if DNA synthesis was not apparent in the negative control. The PCR product was precipitated and purified with NH4Ac (4 M) and isopropanol, washed with ethanol (70\%) and dissolved in $60 \mu \mathrm{l}$ T0,1E buffer $(10 \mathrm{mM}$ TRIS-HCl/0,1 mM Na2EDTA, pH 8.0).

\section{Fluorescence in situ hybridization (FISH).}

PCR products were labeled by nick-translation with biotin-14-dATP (BioNick TM labeling system (Gibco BRL)). Metaphase spreads for FISH were prepared from PHAstimulated lymphocytes using standard methanol: acetic acid (3:1) fixation. In situ hybridization was performed following the protocol by Guan et al. ${ }^{7}$ with only minor modifications. Briefly, for hybridization, $200 \mathrm{ng}$ probe was used in $10 \mu 1$ hybridization mixture containing $50 \%$ formamide, $2 \times \mathrm{SSC}, 10 \%$ dextran sulphate, $50 \mathrm{mM}$ phosphate and $20 \mu \mathrm{g}$ human Cot 1 DNA (BRL). Probe and Cot 1 DNA were denaturated at $70^{\circ} \mathrm{C}$ for $5 \mathrm{~min}$ and reannealed at $37^{\circ} \mathrm{C}$ for $90 \mathrm{~min}$. Slides were denaturated in $70 \%$ formamide, $2 \times S S C(\mathrm{pH} 7.0)$ at $70^{\circ} \mathrm{C}$ for $3 \mathrm{~min}$, dehydrated and hybridized with probe at $37^{\circ} \mathrm{C}$ overnight in a moist chamber. Slides were then washed four times in $2 \times S S C$ (pH7.0) at $45^{\circ} \mathrm{C}$ for $5 \mathrm{~min}$ and one wash in $\mathrm{PN}$ buffer (0.1 M sodium phosphate, $0.1 \%$ ( $\mathrm{v} / \mathrm{v}$ ) Nonidet $\mathrm{P}-40, \mathrm{pH} 8.0$ ) at $45^{\circ} \mathrm{C}$ for $10 \mathrm{~min}$. The hybridization signal was detected by three layers of fluorescein-avidin DCS (Vector) amplified by two layers of biotinylated anti-avidin $\mathrm{D}$ (Vector), followed by two washes with $4 \mathrm{xSSC}, 0.5 \%$ Tween and one wash with PBS. Slides were dehydrated and counterstained with DAPI/PI in antifade solution. Analysis was carried out using a Zeiss Axiophot microscope and photographs taken with Scotch chrome 640 ASA colour slide film. 


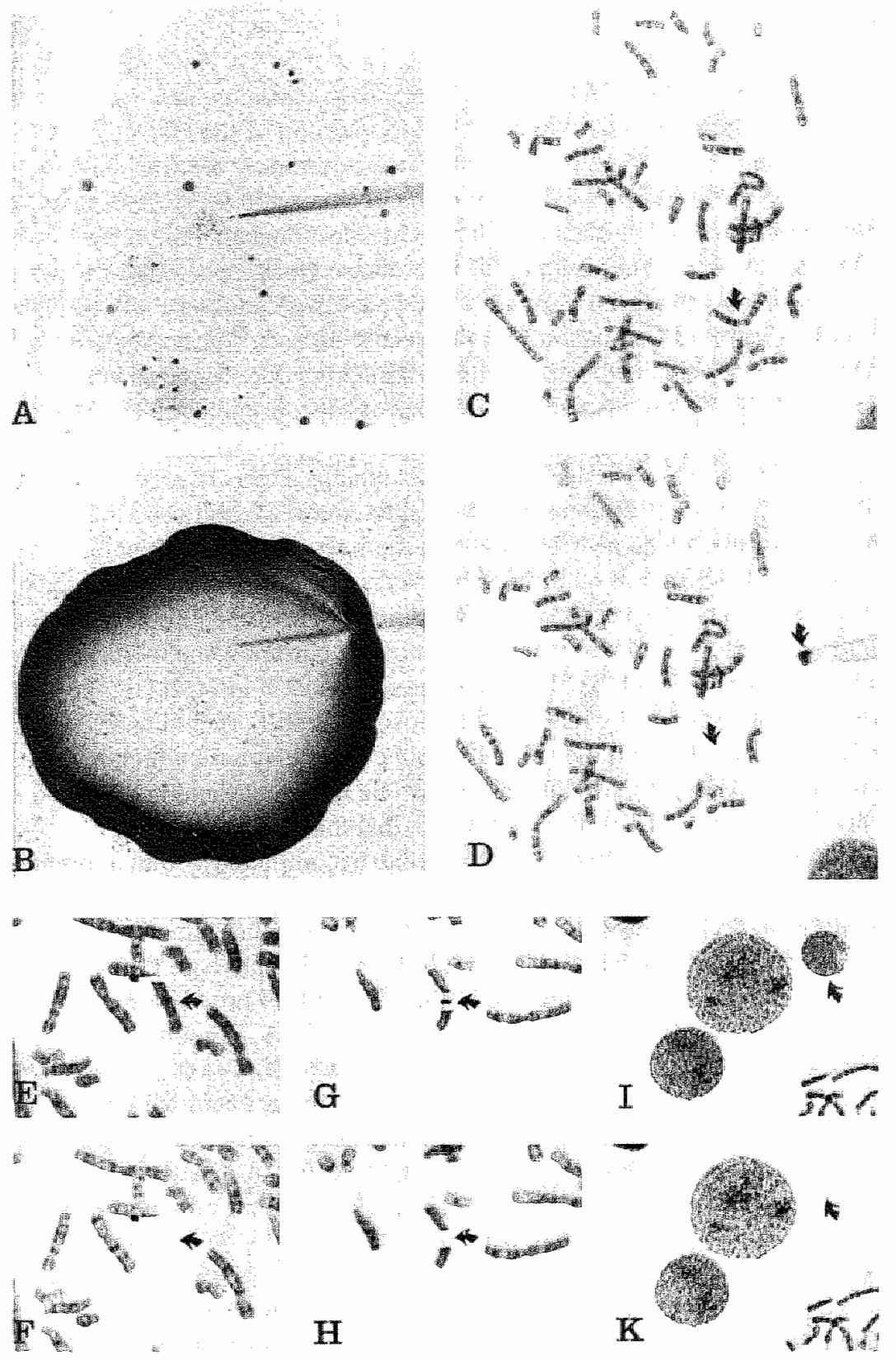

Fig. 1: Procedure followed during microdissection, a: Location of a well spread metaphase and installation of the microneedle. $\mathbf{b}$ : Covering of the metaphase with Milli-Q water.

c and d: Dissection of chromosome 1. e and f: Dissection of the q-arm of chromosome 2. $\mathrm{g}$ :

Removal of centromere 7 and band $7 \mathrm{q} 13$. $\mathbf{h}$ : Dissection of chromosome region $7 \mathrm{q} 1 \mathrm{l}-\mathrm{q} 1.2 . \mathrm{l}$ and $\mathrm{k}$ :

Dissection of a micronucleus. 


\section{Results and discussion}

In the procedure that is nowadays used to prepare metaphase chromosomes for microdissection, special attention is paid to prevent depurination of the DNA (Mezzanotte et al. ${ }^{\mathrm{g}}$ ). When preparing slides for microdissection they are washed with distilled water to remove acetic acid and then immediately stored in $98 \%$ ethanol at -20 ${ }^{\circ} \mathrm{C}$. Due to fixation procedure and storage in ethanol chromosomes are dehydrated and become hard (Claussen et al. ${ }^{9}$ ). This hampers the microdissection, especially of whole chromosomes and chromosome regions. An additional problem that frequently occurs is the repulsion of the dissected fragments from the needle. Bussey ${ }^{10}$ described it fondly as the "Mexican jumping bean" phenomenon. The procedure reported here overcomes these problems. Before microdissection of a whole chromosome, a marker chromosome or a micronucleus, the microneedle is brought into the field within a few micrometers of a well spread metaphase (fig. 1a). This metaphase is covered with $2 \mu 1$ milli-Q water (fig. 1b), the microneedle is then moved down on the slide and the (marker) chromosome of interest is detached entirely from the slide using just one needle (fig. 1d). For the dissection of a chromosome region or a chromosome band a slightlly different procedure has to be followed. First, the chromosome region or chromosome band of interest is isolated from the rest of the chromosome by dissecting the chromosome parts proximal and distal of the region or band of interest (fig. le and lg). This manipulation is performed when the chromosome is still dry and hard. Next, a new microneedle is installed, positioned slightly above the metaphase which is then covered with $2 \mu \mathrm{l}$ milli-Q water. Finally, the chromosome region or band is dissected using only one needle (fig. If and $1 \mathrm{~h}$ ). Beside the fact that this procedure of microdissection is very fast, dissection of a chromosome is completed within a minute, a second advantage is that the microdissected chromosome part sticks tightly to the needle tip (even after the tip is removed out of the water drop) without the risk of loosing the dissected fragment when transferring it to the microcentrifuge tube containing the collection drop. The second step in the micro-FISH procedure is treatment of the dissected material to dissolve chromosomal DNA. Proteinase-K treatment (Jinno et al ${ }^{11}$; Deng et al. ${ }^{12}$; Meltzer et al. ${ }^{4}$ ) is used to digest the proteins that are associated with the DNA of mitotic chromosomes and also pretreatment with topoisomerase $I$ is advised (Guan et al. ${ }^{13}$ ) to enhance the accessibility of the dissected DNA for primers and polymerase during the following PCR. In our experiments the samples were cycled for 20 cycles of $30^{\circ} \mathrm{C}$ for $1 \mathrm{~min}$ and $50^{\circ} \mathrm{C}$ for $1 \mathrm{~min}$, without proteinase-K or topoisomerase treatment, which led to a yield of DNA after DOP-PCR comparable with the proteinase- $K$ method we used previously (Engelen et al. ${ }^{14,15,16}$ ). The most crucial step in micro-FISH is, without any doubt, the amplification of the dissected material using DOP-PCR. Although various protocols for DOP-PCR exist, most authors prefer at the moment the method developed by Guan et al. ${ }^{13}$. In the first 8 cycles of this method, when the annealing temperature is low, T7 DNA polymerase (Sequenase) is used. However, Sequenase is heat inactivated at the denaturation temperature of $94^{\circ} \mathrm{C}$ and consequently active Sequenase has to be added 8 times. For this reason, these steps are a prime target for contamination. In the method described 
here the use of Sequenase is omitted, which reduces the risk of extraneous contamination considerably.

For standard applications a primer concentration between 0.1 and $1 \mu \mathrm{M}$ is recommended (Rolfs et al. ${ }^{17}$ ) and rarely the primers are completely used up during the reaction. Nevertheless, the primers have to compete with the accumulating product in finding the target sequences, which could become a limiting factor for the reaction, certainly at the late cycles. We decided to use a high primer concentration $(4 \mu \mathrm{M})$ in our experiments, as Czerny ${ }^{18}$ showed that primer limitation can make a critical contribution to the attenuation of amplification rates observed for late cycles of PCR. As an example, fig. 2a shows the results of micro-FISH of the q-arm of chromosome 2, dissected in fig. $1 \mathrm{e}$ and $1 \mathrm{f}$. Furthermore, fig. $2 \mathrm{e}$ shows that a micronucleus from a patient with ICF syndrome (Smeets et al. ${ }^{19}$ ) contains DNA derived from chromosome 1 , and fig. $2 \mathrm{c}$ shows a chromosome $7 \mathrm{q} 12$ band-specific paint.

In conclusion, the modified microdissection method described here enabled fast and reliable dissection of chromosomes and regions of chromosomes. Furthermore, relaxation of the dissected material was achieved without extra additives, an efficient DOP-PCR reaction mix was composed and reduction of the risk of extraneous contamination was reached by omitting Sequenase addition. 


\section{References}

1. Bates GP, Wainwright BJ, Williamson R, Brown SDM: Microdissection and microeloning from the short arm of human chromosome 2. Mol Cell Biol 6:3826-3830 (1986).

2-Ludecke HJ, Senger G, Claussen U, Horsthemke B: Cloning defined regions of the human genome by microdissection of banded chromosomes and enzymatic amplification. Nature 338:348-350 (1989).

3-Senger G, Lidecke HJ, Horsthemke B, Claussen U: Microdissection of banded human chromosomes. Hum Genet 84:507-511 (1990).

4-Meltzer PS, Guan XY, Burgess A, Trent d: Rapid generation of region specific probes by chromosome microdissection and their application. Nature Genet 1:24-28 (1992).

5-Dutrillaux B, Viegas-Pequignot E: High resolution R- and G-banding in the same preparation. Fum Genet 57:93-91 (1981).

6-Telenius H, Carter NP, Bebb CE, Nordenskjold M, Ponder BA, Tunnacliffe A: Degenerate oligonucleotide-primed PCR: general amplification of target DNA by a single degenerate primer. Genomics 13:718-725 (1992).

7.Guan XY, Cargille CB, Anzick SL, Thompson FH, Meltzer PS, Bitmer ML, Taetle R, McGill JR, Trent JM: Chromosome microdissection identifies cryptic sites of DNA sequence amplification in human ovarian carcinoma. Cancer Res 55:3380-3385 (1995).

8-Mezzanotte R, Vanni R, Flore O, Ferrucci L, Sumner AT: Ageing of fixed cytological preparations produces degradation of chromosomal DNA. Cytogenet Cell Genet 48:60-62 (1988).

9- Claussen U, Mazur A, Rubtsov N: Chromosomes are highly elastic and can be stretched. Cytogenet Cell Genet 66:120-125 (1994).

10- Bussey KJ: Chromosome microdissection: On the cutting edge. Applied Cytogenet 22:2:30-36 (1996).

11-Jinno $Y$, Harada $N_{s}$ Yoshiura $K$, Ohta T, Tohma T, Hirota T, Tsukamota K, Deng HX, Oshimura $M$, Niikawa $N$ : A simple and efficient amplification method of DNA with unkwown sequences and its application to microdissection/microcloning. J. Biochem 112:775-80 (1992).

12. Deng HX, Yoshiura KI, Dirks RW, Harada N, Hirota T, Tsukamoto K, Jinno Y, Niikawa N: Chromosome-band-specific-painting: chromosome in situ suppression hybridization using PCR products from a microdissected chromosome band as a probe tool. Hum Genet 89:13-17 (1992). 13-Guan XY, Trent JM, Meltzer PS: Generation of band-specific painting probes from a single microdissected chromosome. Hum Mol Genet 8:1117-1121 (1993).

14- Engelen JJM, Loots WJG, Motoh PCC, Moog U, Hamers AJH, Geraedts JPM: Marker chromosome identification by micro-FISH. Clin Genet 49:242-248 (1996a).

15- Mingelen JJM, Loots WJG, Albrechts JCM, Motoh POC, Fryns JP, Hamers AJH, Geraedts IPM: Disclosure of five breakpoints in a complex chromosome rearrangement (CCR) by microdissection and ELSH. J Med Genet 33:562-566 (1996b).

16- Engelen JJM, Albrechts JCM, Loots WJG, Hollanders-Crombach HTM, Hamers AJH, Geraedts JPM: Application of micro-FISH to delineate deletions. Cytogenet Cell Genet 75:167-171 (1996). 17-Rolfs A, Schuller I, Finckh U, Weber-Rolfs I: PCR: Clinical Diagnostics and Research, Springer Verlag, Berlin (1992),

18- Czerny T: High primer concentration improves PCR amplification from random pools. Nucl Acids Res 24:5:985-986(1996).

19-Smeets DFCM, Moog U, Weemaes CMR, Vaes-Peeters G, Merkx GFM, Hamers AJH: ICF syndrome: a new case and review of the literature. Hum Genet 94:240-246 (1994). 

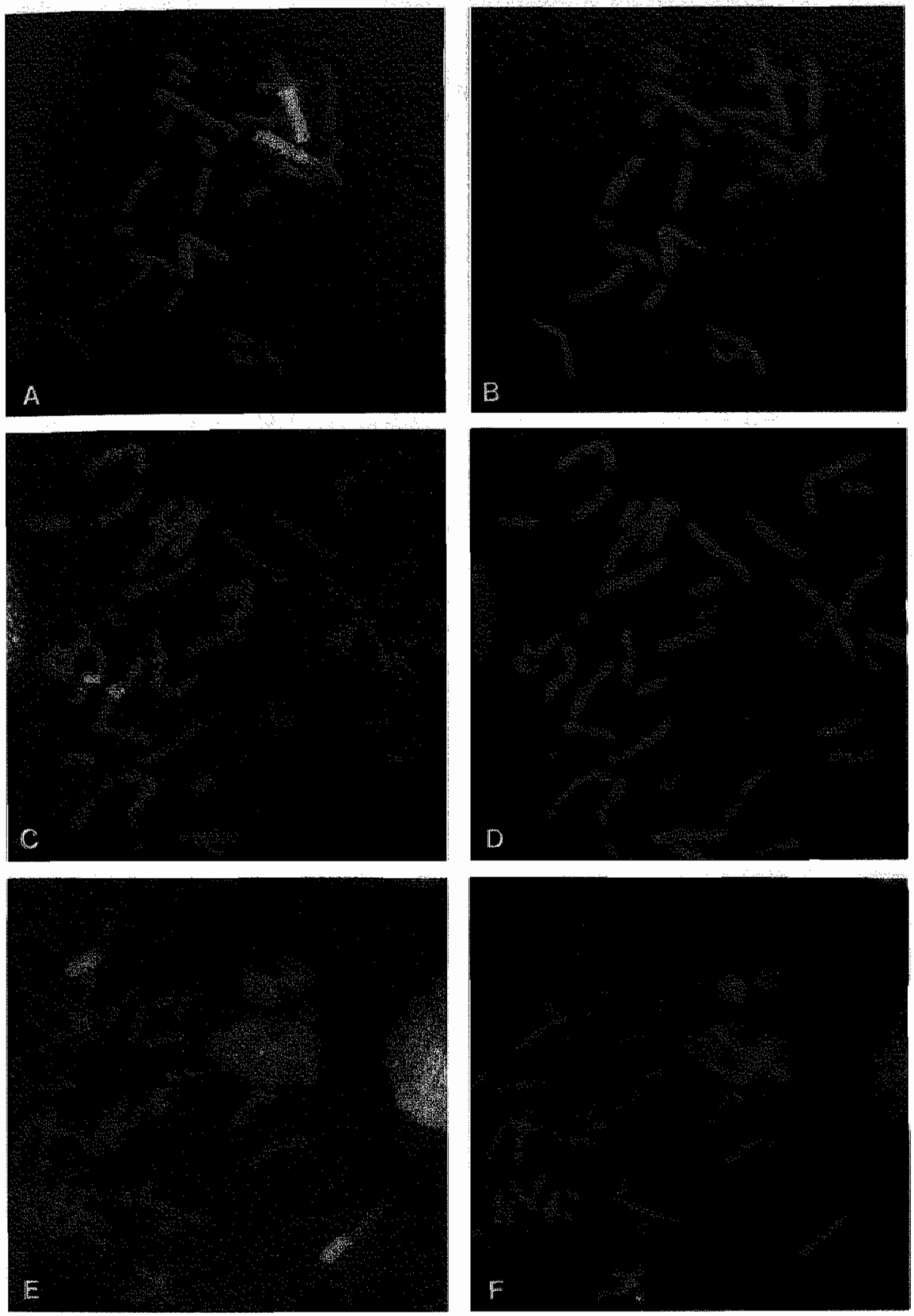

Fig.2: Partial metaphase after reverse painting to a normal metaphase with biotinylated PCR product: a: derived from the $\mathrm{q}$-arm of chromosome 2 . $\mathrm{c}$ : deriwed from chromosome region $7 \mathrm{q} \| 1-\mathrm{q} \mid 2$, $\mathrm{e}$ : derived from the micronucleus of an ICF patient. $\mathbf{b}, \mathbf{d}$ and $\mathbf{f}$ : DADDAPI counterstaining of $a, c$ and $\mathrm{e}$. 


\section{MARKER CHROMOSOME IDENTIFICATION BY MICRO-FISH.}

John J.M. Engelen, Wil J.G. Loots, Petra C.C. Motoh, Ute Moog, Guus J.H. Hamers and Joep P.M. Geraedts.

Department of Molecular Cell Biology and Genetics, University of Maastricht, Maastricht, The Netherlands.

\section{Published in:}

Clinical Genetics 49:242-248 (1996). 
Micro-FISH was used to elucidate the chromosomal origin of marker chromosomes in three patients. Ten copies of marker chromosomes were collected with microneedles from GTG-banded metaphases, transferred to a collecting drop and amplified by means of DOP-PCR. The PCR products were labeled with biotin-14-dATP and used as FISH probes for hybridization to normal metaphase chromosomes and to metaphase chromosomes of the patients (reverse painting). With the generation of chromosome region-specific painting probes by PCR amplification of microdissected DNA and subsequent FISH it was possible to identify the marker chromosomes in all patients. One marker appeared to be derived from the centromere region of the X-chromosome and the proximal third of the long arm, one from the centromere region of chromosome 17 and one marker chromosome was identified as an isochromosome $18 \mathrm{p}$. 


\section{Introduction.}

A marker chromosome (mar) is a structurally abnormal chromosome in which no part can be identified (ISCN 1995). They constitute a heterogenous group of supermumerary chromosomes which often are not identifiable by cytogenetic banding techniques, mainly due to their small size and the lack of a distinct banding pattern. Constitutional markers are found with a frequency of $0.24 / 1000$ in lifeborn individuals (Buckton et al. ${ }^{2}$ ) and $0.4-1.5 / 1000$ at amniocentesis (Hook and Cross ${ }^{3}$, Sachs et al. ${ }^{4}$, Warburton et al. $\left.{ }^{5}\right)$. The incidence of marker chromosomes in mentally retarded patients is reported to be 3.27/1000 (Buckton et al. ${ }^{2}$ ). NOR staining and distamycin A/DAPI staining have shown that over $80 \%$ of the marker chromosomes originate from the pericentromeric regions of the acrocentric chromosomes (Maraschio et al. ${ }^{6}$ ). Approximately $50 \%$ of these markers are DA/DAPI positive and therefore originate from the centromere region of chromosome 15 (Maraschio et al ${ }^{6}$, Blennow et al. ${ }^{7}$, Plattner et al. ${ }^{8}$ ). Beside these conventional staining techniques, more recently, fluorescence in situ hybridization, often preceded by chromosome flow sorting, microcloning or degenerate oligonucleotide primed-PCR (DOP-PCR) has been used to identify marker chromosomes (Rauch et al. ${ }^{9}$, Plattner et al. ${ }^{10}$, Blennow et al. ${ }^{7}$ and Crolla et al.. ${ }^{1}$ ). However, the most straightforward approach for identification is, without any doubt, the physical dissection of marker chromosomes followed by DOP-PCR, labeling of the PCR products and subsequently, reverse painting (micro-FISH). In this study we describe the characterization of two unknown marker chromosomes and we confirm the nature of one cytogenetically identified marker chromosome by FISH with DOPPCR products derived from ten copies of microdissected marker chromosomes.

\section{Material and methods}

\section{Preparation of metaphase chromosomes}

PHA-stimulated peripheral blood lymphocytes were cultured and harvested following the standard procedures. Routinely fixed (methanol:acetic acid 3:1) cell suspensions stored at $-20^{\circ} \mathrm{C}$ for 3 (patient A), 5 (patient B) and 10 months (patient C) were used to prepare metaphase spreads on $45 \times 65 \mathrm{~mm}$ coverslips. The slides were rinsed in water and stored in $98 \%$ ethanol at $-20^{\circ} \mathrm{C}$ until the day of microdissection. GTGubanding was performed prior to microdissection.

\section{Microdissection and amplification of chromosomal DNA}

From ten different metaphases marker chromosomes were collected by microdissection using glass microneedles controlled by a Narishige micromanipulator (MO-202). Before use, microneedles and microcentrifuge tubes were treated with UV light for 30 $\mathrm{min}$. The dissected marker chomosomes were transferred to a $20 \mu \mathrm{l}$ collection drop (containing $250 \mu \mathrm{g} / \mathrm{ml}$ proteinase- $\mathrm{K}$ ) in a $0.5 \mathrm{ml}$ microcentri fuge tube. A fresh microneedle was used for each marker chromosome. Before DOP-PCR, the collection drop containing ten copies of the markers, was incubated at $37^{\circ} \mathrm{C}$ for $30 \mathrm{~min}$ (proteinase- $\mathrm{K}$ treatment) and at $90^{\circ} \mathrm{C}$ for $10 \mathrm{~min}$ (proteinase- $\mathrm{K}$ inactivation). DOP- 
PCR reactions were performed following the protocol of Guan et al. ${ }^{12}$ in a Biometra personal cycler with a heated lid. PCR products were analysed for yield and probe size (200-800 bp) on an agarose gel after staining with ethidium bromide. The PCR product was precipitated and purified with $\mathrm{NH} 4 \mathrm{Ac}(4 \mathrm{M})$ and isopropanol, washed with ethanol (70\%) and dissolved in $50 \mu \mathrm{l}$ T0,1E buffer ( $10 \mathrm{mM}$ TRIS-HCl/0, I mM Na2EDTA, pH $8.0)$.

\section{Fluorescence in situ hybridization (FISH).}

PCR products were labeled by nick-translation with biotin-14-dATP. Metaphase spreads for FISH were prepared from PHA-stimulated lymphocytes using the standard $3: \mathbb{1}(\mathrm{v} / \mathrm{v})$ methanol: acetic acid fixation protocol. In situ hybridization was performed following the protocol of Pinkel et al..$^{13}$ with only minor modifications. For hybridization, $200 \mathrm{ng}$ probe was used in $10 \mu \mathrm{l}$ hybridization mixture containing $50 \%$ formamide, $2 \mathrm{xSSC}, 10 \%$ dextranesulphate, $50 \mathrm{mM}$ phosphate, $3 \mu \mathrm{g}$ human Cot $1 \mathrm{DNA}$ and $10 \mu \mathrm{g}$ salmon sperm DNA. Whole chromosome painting with chromosome specific paint was performed according to the manufacturer's specification (Oncor). Analysis were carried out using a conventional Zeiss epifluorescent Axiophot microscope and photographs taken with Scotch chrome 640 ASA colour slide film.

\section{Clinical reports and cytogenetics}

Patient A was an 11-year-old girl referred for chromosome investigation because of growth retardation (height $=126 \mathrm{~cm},<\mathrm{P} 3$ ). Clinical features suggestive for Turner syndrome were low posterior hairline, shield chest, widely spaced nipples, numerous naevi and dysplastic toe nails. The child was not mentally retarded and displayed no other dysmorphic features.

Analysis of GTG-banded chromosomes of the patient revealed that only one Xchromosome was present in $40 \%$ of the cells while $60 \%$ had beside a normal Xchromosome a marker chromosome (Fig. 1A). The karyotype formula was mos $45, \mathrm{X} / 46, \mathrm{X}$, +mar. Conventional Giemsa staining and $\mathrm{C}$-banding showed that the marker chromosome was not a ring chromosome and had a centromere (Fig. 1B). The size of the marker was similar with that of the G-group chromosomes. NOR-staining showed that there were no satellites. The karyotypes of the parents were normal.

Patient B was a 42-year-old female with moderate mental retardation, small stature, asthenic body habitus and microcephaly ( $\mathrm{HC} 50,5 \mathrm{~cm},<\mathrm{P} 3)$ ). Facial features included oval facial shape, narrow forehead, up-slanting and small palpebral fissures (PFL 2,5 $\mathrm{cm}$ bilaterally, $<-2 \mathrm{SD}$ ), hypotelorism (ICD $2,5 \mathrm{~cm},<-2 \mathrm{SD}$ ), a small nose and slightly malformed ears.

In all cells of the patient an extra isochromosome (Fig. 1C) was present, the karyotype being $47, \mathrm{XX}$, +mar. The GTG banding pattern suggested an isochromosome $18 \mathrm{p}$. Both parents had normal karyotypes.

Patient $\mathrm{C}$ was a 4-year-old girl referred for cytogenetic examination because of growth retardation, delayed speech development and muscle weakness, predominantly of the distal lower limbs. Chromosome analysis showed a normal $46, \mathrm{XX}$ karyotype in $12 \%$ of the cells, a $47, \mathrm{XX},+$ mar karyotype in $40 \%$ and a $48, \mathrm{XX}$, +mar,+mar karyotype in 
$48 \%$ of the cells. In GTG-banded metaphases all marker chromosomes had the same appearance and size, which was about half that of chromosome 21 (Fig. 1D). Conventional Giemsa staining revealed that we were not dealing with a ring chromosome. NOR staining showed that the markers had no satellites and C-banding showed that a centromere was present (Fig. 1E). Both parents had normal karyotypes.

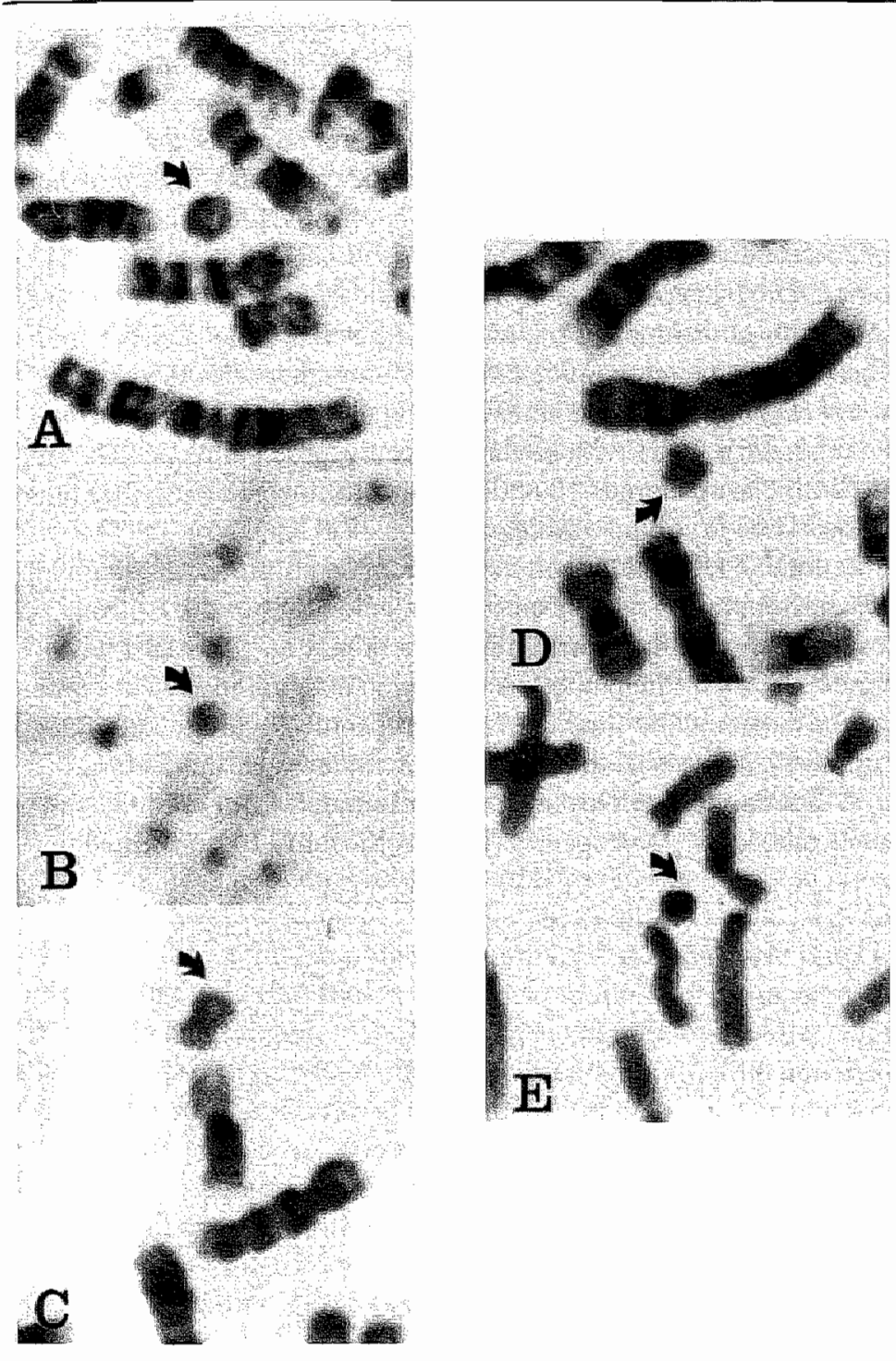

Fig. 1A: GTG-banded marker chromosome of patient A. 1B: C-banded marker chromosome of patient A. 1C: GTG-banded marker chromosome of patient B. 1D: GTG-banded marker chromosome of patient C. $1 \mathrm{E}$ : C-bandled marker chromosome of patient $\mathrm{C}$. Arrows point to the marker chromosome. 


\section{Results}

Patient A: FISH on normal female metaphase chromosomes with the DOP-PCR product showed signals in the centromeres of two chromosomes of the C-group and a signal extending in the long arm (Fig. 2A). After analysis of the DAPI counterstained chromosomes it became clear that the chromosomes involved were the Xchromosomes. FISH on metaphase chromosomes of the patient with the DOP-PCR product again showed a strong signal in the centromere of the $\mathrm{X}$-chromosome and a (weaker) signal on the proximal third of the $q$-arm. On the marker chromosome a strong signal was present in what is presumably the centromere, however the euchromatic region of the marker was less intensively stained (Fig. 2B). Chromosome painting with a whole chromosome paint specific for the $\mathrm{X}$-chromosome showed that the marker chromosome consisted completely of X-chromosomal material (Fig. 2D). Patient B: FISH with the DOP-PCR probe on normal female metaphase chromosomes (Fig. 2E) and on metaphase chromosomes of the patient showed that the short arm of two chromosomes of the E-group were completely stained, together with the marker chromosome in the patient (Fig. 2F). DAPI counterstaining showed that chromosome 18 was indeed involved (Fig. 2G). FISH with a whole chromosome paint specific for chromosome 18 painted both chromosomes 18 and the isochromosome (Fig. $2 \mathrm{H}$ ) thus confirming our conclusion. The karyotype of this patient is $47, \mathrm{XX}, \mathrm{i}(18 \mathrm{p})$.

Patient C: FISH with the DOP-PCR product on normal female chromosomes showed fluorescent spots in the centromeres of two chromosomes belonging to the E-group and some fluorescence on the short arm of these chromosomes (Fig. 2J). FISH with DOP-PCR product on metaphases of the patient also showed a signal in the centromere of two chromosomes of the E-group and the marker chromosomes, which were completely painted (Fig. 2K). Analysis of the DAPI counterstained chromosomes (Fig. $2 \mathrm{~L}$ ) led to the conclusion that the marker chromosomes originated from chromosome 17. FISH with a whole chromosome paint specific for chromosome 17 confirmed this conclusion (Fig. 2M). 


\section{Discussion}

In recent years several FISH methods have been developed and used for the identification of marker chromosomes. Firstly, FISH with chromosome specific probes (Schwartz et al. ${ }^{14}$, Callen et al. ${ }^{15}$, Rauch et al. ${ }^{9}$ ) provided a tool for identification. Stepwise hybridization with alpha-satellite probes under multiple stringency conditions was used by Plattuer et al. ${ }^{8,10}$ to identify 20 small DA/DAPI negative ring and 7 DADAPI positive marker chromosomes. Secondly, fluorescence activated cell sorting and DOP-PCR enabled Carter et al. ${ }^{16}$ and Blennow et al ${ }^{3}$ to construct marker specific libraries. However, chromosome size (Young ${ }^{17}$ ) and marker chromosome heterogeneity (Cram et al. ${ }^{18}$ ) are limiting factors in chromosome sorting. Thirdly, Senger et al. ${ }^{19}$, Lengauer ef al. ${ }^{20}$ and Hirota et al. ${ }^{211}$ used (laser)-microdissection in combination with microcloning for chromosome region-specific cloning and probe generation. Lastly, biotin-1 1 -dUTP labeled. PCR products of microdissected chromosomes were directly used for reverse painting (Meltzer et all. ${ }^{22}$, Deng et al ${ }^{23}$, Guan et al. ${ }^{24,25}$ ). Deng et al. ${ }^{23}$ used Sau3A1 digests of 5-10 chromosome fragments for linker-primer PCR. Meltzer et all $^{22}$ who initially worked with 25-50 microdissected copies, were able to reduce the copy number to 1 (Guan et al. ${ }^{24}$ ) by treatment of the DNA with topoisomerase I before DOP-PCR. The latter approach could be particularly suitable in tumor cytogenetics where material is very limited. Thangavelu et al. ${ }^{26}$, Viersbach et al. ${ }^{27}$ and Sun et al. ${ }^{28}$ used micro-FISH for the identification of marker chromosomes. However, the DOP. PCR probes they generated showed cross-hybridization to the satellites of chromosomes of the D- and G-group. Highly repetitive beta satellite DNA present in the short arms of the acrocentric chromosomes (Waye and Willard ${ }^{29}$ ) might be responsible for this cross-hybridization. They came to a final identification of the marker chromosomes using specific probes for the chromosomes involved.

Our study has demonstrated that microdissection of marker chromosomes followed by DOP-PCR can be used to generate probes that hybridize all over the marker chromosome without systematic cross-hybridization to non-targeted chromosomes. MicroFISH is a reliable method to identify marker chromosomes, because they can easily be recognized due to the combination of reverse painting and DADAPI counterstaining. Patient $A$ has a marker that is derived from the $X$-chromosome, containing the centromere and the region $\mathrm{Xq} 11$ to $\mathrm{Xq} 21$. Individuals with a cell line containing a small mar $(X)$ chromosome often have mental retardation and dysmorphic features uncharacteristic for Turner syndrome (Wolff et al. ${ }^{30}$ ). The abnormalities seen in these patients may be due to failure of $X$-chromosome inactivation, resulting in functional disomy of pericentromeric sequences (Van Dyke et al. "). Our patient has a Turner" syndrome phenotype without influence of the marker chromosome on her phenotype, probable due to the presence of the $X$-inactivation center in the marker and nonrandom inactivation of the marker. After micro-FISH a strong signal was present in presumably the centromere of the marker chromosome and a weaker signal on the euchromatine derived from the q-arm. Perhaps the highly repetitive DNA sequences that exist in centromere regions (Waye and Willard ${ }^{29,32}$ ) are responsible for this difference in signal intensity, although it was not present in both other marker chromom somes. In patient B a $47, \mathrm{XX}, \mathrm{i}(18 \mathrm{p})$ karyotype was found by cytogenetic analysis and 
confirmed with micro-FISH. Her clinical features correspond well with the isochromosome $18 \mathrm{p}$ syndrome (Callen et al. ${ }^{33}$ ). Patient $\mathrm{C}$ has a mosaic

$46, \mathrm{XX} / 47, \mathrm{XX}$, +mar $/ 48, \mathrm{XX}$, +mar, , mar karyotype whose marker chromosome is derived from the centromere region of chromosome 17. Although Hagag and Viola ${ }^{34}$ and several other authors mentioned that acetic acid fixation of the cells causes degradation of the DNA by depurinization and recommend a short fixation time and ethanol treatment of cells, our results with a fixed cell suspension kept at $-20^{\circ} \mathrm{C}$ for three years were quite satisfactory (unpublished data).

The advantages of micro-FISH above the methods mentioned before are that it is less time consuming then the microcloning procedures (a marker chromosome can be identified in three days) and in comparison to chromosome sorting, the size of the marker is not a limiting factor. Furthermore, only a small number of dissected chromosomes is needed and at least up to three years old fixed cell suspensions can be used making retrospective analysis possible. Finally, marker identification with centromere probes or paints discloses the origin of the marker but not the chromosome region involved. Since the collection of banded chromosomes by microdissection can be precisely controlled, libraries for screening can be made, beside chromosome regionspecific and chromosome band-specific paints. Thus, micro-FISH is applicable not only for cytogenetically unidentifiable marker chromosomes, but also for the diagnosis of numerical and structural chromosome abnormalities and genome analysis. 
Fig. 2A: FISH with the DOP-PCR probe of patient $A$ on a metaphase of a normal woman. 2B: DOP. PCR probe of patient $A$ hybridized to a metaphase of patient $A .2 C: D A D A P I$ counterstaining of $2 b$. 2D: X-chromosome specific paint hybridized to a metaphase of patient A. 2E: FISH with the DOPPCR probe of patient $B$ on a metaphase of a normal woman. $2 F$ : DOP-PCR probe of patient $B$ hybridized to a metaphase of patient B. 2G: DA/DAPI counterstaining of $2 \mathrm{f}$. $2 \mathrm{H}:$ Chromosome 18 specific paint hybridized to a metaphase of patient B. 2J: FISH with the DOP-PCR probe of patient C on a metaphase of a normal woman. $2 \mathrm{~K}$ : DOP-PCR probe of patient $C$ hybridized to a metaphase of patient C. 2L: DA/DAPI counterstaining of $2 \mathrm{~K}$. 2M: Chromosome 17 specific paint hybridized to a metaphase of patient $C$. Large arrows point to the marker chromosomes; small arrows point to the normal chromosomes from which the marker chromosomes originate. 

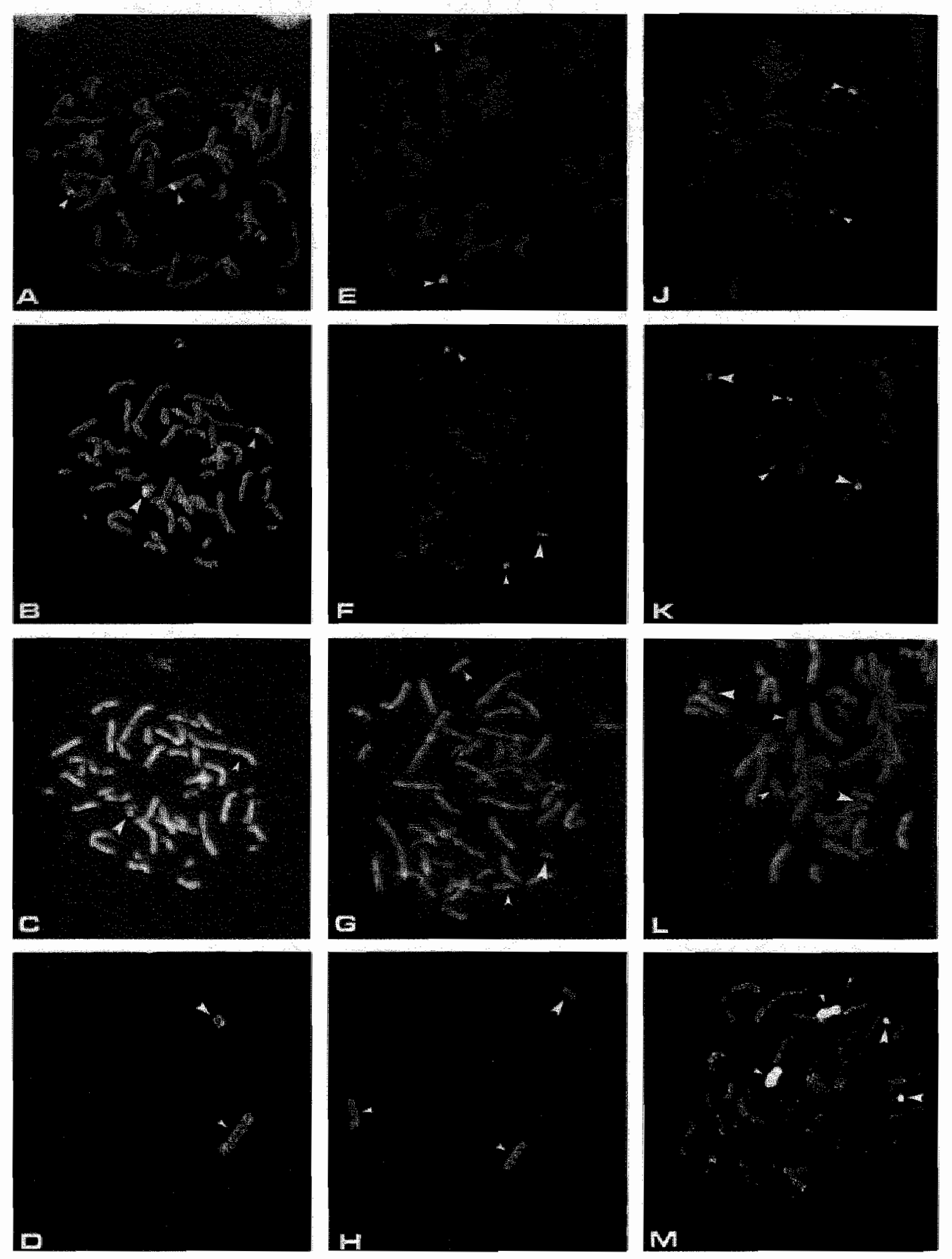


\section{References}

1-ISCN (1995): An International System for Human Cytogenetic Nomenclature, Mitelman F. (Ed); S. Karger, Basel (1995).

2- Buckton KE, Spowart G, Newton MS, Evans HJ: Forty four probands with an additional "marker" chronosome. Hum Genet 69: 353-370 (1985).

3-Hook EB, Cross PK: Extra structurally abnomal chromosomes (ESAC) detected in amniocentesis: frequency in approximately 75,000 prenatal cytogenetic diagnoses and association with maternal and paternal age. Am J Hum Genet 40:83-101 (1987).

4-Sachs ES, van Hemel JO, Den Hollander JC, Jahoda MGJ: Marker chromosomes in a series of 10000 prenatal diagnoses. Cytogenetic and follow-up studies. Prenat Diagn 7:81-89(1987).

5-Warburton D: De nowo balaneed chromosome rearrangements and extra marker chromosomes identified at prenatal diagnosis: dinical significance and distribution of breakpoints. Am J Hum Genet 49:995-1013 (1991).

6-Maraschio $\mathrm{P}$, Cuoco $\mathrm{C}$, Gimelli $\mathrm{G}, \mathrm{Zuffardi} \mathrm{O}$, Tiepolo L: Origin and clinical significance of inv dup(15). In: Daniel A, ed. The cytogenetics of mammalian autosonal rearrangements, New York: Alan R. Liss, 615-634 (1988).

7- Blennow E, Brondum Nielsen K. Telenius $\mathrm{H}_{8}$ Carter NP, Kristofferson U, Holmberg $\mathrm{E}_{\mathrm{x}}$ Gillberg $\mathrm{C}$, Nordenskjold M: Fifty probands with extra structurally abnormal chromosomes characterized by fluorescence in situ hybridization. Am J Med Genet 55:85-94 (1995).

8-Plattner R, Heerema NA, Patil SR, Howard-Peebles PN, Palmer CG: Characterization of seven DADAPI-positive bisatelited marker chromosomes by in situ hybridization. Hum Genet 87: 290-296 (1991).

9-Rauch A, Pfeiffer RA, Trautman U, Jiehr T, Rott HD, Llmer R: A study of ten small supermumerary (marker) chromosomes identified by fluorescence in situ hybridization (FISH). Clin Genet 42:8490 (1992).

10-Plattner R, Heerema NA, Howard-Peebles PN, Miles JH, Soukop S, Palmer CG: Clinical findings in patients with marker chromosomes identified by fluorescence in situ hybridization. Hum Genet 91:589-598 (1993).

11- Crolla JA, Harvey JF, Sitch FL, Dennis NR: Supernumerary marker 15 chromosomes: a clinical, molecular and FISH approach to diagnosis and prognosis. Hum Genet 95:161-170 (1995).

12- Guan XY, Meltzer PS, Cao J, Trent JM: Rapid generation of region-specific genomic clones by chromosome microdissection: isolation of DNA from a region frequently deleted in malignant melanoma. Genomics 14:680-684 (1992).

13-Pinkel D, Straume T, Gray JW: Cytogenetic analysis using quantitative, high sensitive fuorescense hybridization. Proc Natl Acad Sci USA 83:2934-2938 (1986).

14-Schwartz $\mathrm{S}$, Wolff DJ, Zackowski JL: Identification of chromosomal markers and rearrangements utilizing fuorescence in situ hybridization. Cytogenet Cell Genet 56:224 (1991).

15- Callen DF, Eyre H, Yip MY, Freemantle J, Haan EA: Molecular cytogenetic and clinical studies of 42 patients with marker chromosomes. Am J Med Genet 43:709-715 (1992).

16- Carter NP, Ferguson-Smith MA, Perryman MT, Telenius H, Pelmear AH, Leversha MA, Glancy MT, Wood SL, Cook K, Dyson HM, Ferguson-Smith ME, Willat LR: Reverse chromosome painting: a method for the rapid analysis of aberrant chromosomes in clinical cytogenetics. I Med Genet

29:299-307 (1992).

17-Young BD: Human chromosome analysis by flow cytometry. In: J. Gray Ed. Flow cytogenetics, New York: Academic Press, 1 -15 (1989).

18- Cram LS, Bartoldi MF, Ray FA, Cassidy M, Kraemer M: Univariate flow karyotype analysis. In: J. Gray Ed. Flow cytogenetics, New York: Academic Press, 113-135 (1989).

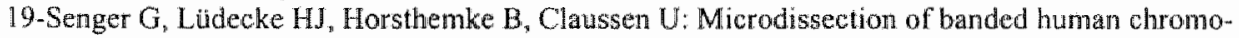
somes. Hum Genet 84:507-511 (1990).

20-Lengauer C, Eckelt A, Weith A, Endlich N, Ponelies N, Lichter P, Gruelich KO, Cremer I]:

Painting of defined chromosomal regions by in situ suppression hybridization of libraries from lasermicrodissected chromosomes. Cytogenet Cell Genet 56:27-30 (1991). 
21-Hirota T, Tsukamoto K, Deng HDX, Yoshiura KI, Ohta T, Tohma T, Kibe T, Harada N, Jinno Y, Niikawa $\mathrm{N}$ : Microdissection of human chromosomal regions $8 \mathrm{q} 23.3 \mathrm{-q} 24.11$ and $2 \mathrm{q} 33$-qter: Construction of DNA libraries and isolation of their clones Genomics 13:349-354 (1992).

22- Meltzer PS, Guan XX, Burgess A, Trent J: Rapid generation of region specific probes by chromosome microdissection and their application. Nature Genet 124-28 (1992).

23. Deng HX, Yoshiura KI, Dirks RW, Harada N, Hirota T, Tsukamoto K, Jinno Y, Niikawa N: Chronosome-band-specific-painting chromosome in situ suppression hybridization using PCR products from microdissected chromosome band as a probe tool Hum Genet 89:13-17 (1992). 24.Guan XY, Trent JM, Meltzer PS: Generation of band-specific painting probes from a single microdissected chromosome. Hum Mol Genet 8: $1117-1121$ (1993).

25 Guan XY, Meltzer PS, Trent JM: Rapid generation of whole chromosome painting probes (WCPs) by chromosome microdissection. Genomics 22:101-107 (1994).

26* Thangavelu M, Perganent E, Espinosa $\mathrm{R}$, Bohlander SK. Characterization of marker chromosomes by microdissection and fluorescence in situ hybridization. Prenat Diagn 14:583-588 (1994). 27-Viersbach R, Schwanitz G, Nothen M: Delineation of marker chromosomes by reverse chromosome painting using only a small number of DOP-PCR amplified mierodissected chromosomes. Hum Genet 93:663-667 (1994).

28-Sun Y, Rubinstein J, Soukup S, Palmer CG: Marker chromosome 21 identified by microdissection and FISH. Am J Med Genet 56:151-154 (1995).

29-Waye J, Willard HF: Human B satellite DNA: Genomic organization and sequence definition of a class of highly repetitive tandem DNA. Proc Natl Acad Sci USA 86:6250-6254 (1989).

30-Wolff DJ, Brown CJ, Schwartz S, Duncan AMV, Surti U, Willard HF: Small marker chromosomes lack the $X$ inactivation center: implications for karyotype/phenotype correlations. Am J Hum Genet 55:87-95 (1994).

31-Van Dyke DL, Wiktor $A_{\text {, }}$ Robertson JR, Weiss L: Mental retardation in Turner syndrome. J Pediatr 118:415-417 (1991).

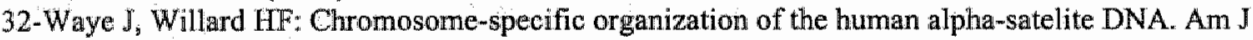
Hum Genet 37:524-532 (1987).

33- Callen DF, Freemantle CJ, Ringenbergs ML, Baker E, Eyre HJ, Romain D, Haan EA: The isochromosome 18p syndrome: Confirmation of cytogenetic diagnosis in nine cases by in situ hybridization. Am J Hum Genet 29:299-307 (1990).

34-Hagag $\mathrm{N}$, Viola MV: Chromosome microdissection and cloning. A practical guide. New York: Academic Press (1993). 
DISCLOSURE OF FIVE BREAKPOINTS IN A COMPLEX CHROMOSOME REARRANGEMENT (CCR) BY MICRODISSECTION AND FISH.

John J.M. Engelen", Wil J.G. Loots', Jozefa C.M. Albrechts', Petra C.C. Motoh", Jean-Pierre Fryns ${ }^{2}$, Guus J.H. Hamers ${ }^{1}$ and Joep P.M. Geraedts'.

"Department of Molecular Cell Biology and Genetics, University of Maastricht, Maastricht, The Netherlands.

${ }^{2}$ Center for Human Genetics, University Hospital, Leuven, Belgium.

Published in:

Journal of Medical Genetics 33:562-566 (1996). 
Microdissection and flworescence in situ hybridization (FISH) were used to elucidate the nature of a complex chromosome translocation, after GTG-banding failed in the complete characterization of the structural rearrangement between chromosomes 6 and 12. These chromosomes were painted with chromosome specific paints and one of the chromosome regions involved in the translocation was isolated by microdissection. Ten copies of the microdissected region were collected with microneedles from GTG banded metaphases, transferred to a collecting drop and amplified by means of DOPPCR. The PCR product was labeled with biotin-14-dATP and used as a FISH probe for hybridization to normal metaphase chromosomes and metaphase chromosomes of the patient (micro-FISH). FISH with this chromosome region-specific painting probe and with chromosome band-specific probes enabled the characterization of a complex chromosome rearrangement with five breakpoints in two chromosomes.

This resulted in the following karyotype: $46, X Y, t(6 ; 12)(6$ pter $\rightarrow 6 q 12: \because 12 q 24.1$

$\rightarrow 12 q t e r ; 12 p t e r->12 q 13.3: \therefore 6 q 16.2->6 q 26: 12 q 13.3->12 q 24.1:: 6 q 12$

$\rightarrow 6 q(6.2 \therefore 6 q 26->6 q t e r)$. 


\section{Introduction}

A complex chromosome rearrangement (CCR) has been defined as an interchange comprising more than two chromosome breaks and reciprocal exchange of segments (Pai et al.'). Since interpretation of a CCR is often difficult when only standard GTGbanding techniques are used, FISH with whole chromosome paints, developed by Pinkel et al. ${ }^{2}$ and Lichter et $\mathrm{al}^{3}{ }^{3}$ is frequently used for characterization of a CCR (Verma et al. ${ }^{4}$, Batista et al. ",6; Wang et al. ${ }^{7}$ ). However, in the case reported here, the application of GTG-banding and whole chromosome painting still did not characterize the CCR completely. Micro-FISH is the physical dissection of (GTG)-banded chromosomes followed by (DOP)-PCR and subsequent FISH with the probe obtained. This method, developed by Meltzer et al. ${ }^{8}$ and Deng et $a{ }^{9}{ }^{9}$ is successfully used to generate whole chromosome painting probes (Guan et $\mathrm{al}^{10}$ ) region-specific probes (Guan ot al. ${ }^{1,12}$ ) and band-specific probes (Hirota et al. ${ }^{13}$, Guan et al. ${ }^{1.4}$ ). In clinicall cytogenetics micro-FISH is used to identify marker chromosomes (Thangavelu et al. ${ }^{15}$; Viersbach et al. ${ }^{16}$; Sun et al. ${ }^{17}$; Engelen et al. ${ }^{18}$ ) and unidentifiable chromosome abnormalities (Ohta et all $\left.{ }^{19}\right)$.

We describe the use of micro-FISH in a case in which chromosomes 6 and 12 are involved in a CCR with five breakpoints (Fig. 1). Whole chromosome painting and micro-FISH were very beneficial in identifying the rearranged segments. Additionally, FISH with centromere-specific probes and band-specific probes was essential for the complete characterization of the CCR.

\section{Material and methods}

\section{Clinicall report}

The patient was an 18-year old male whose chromosomes were re-examined because of a strong suspicion of an unbalanced karyotype. Cytogenetic analysis at three years of age had revealed a reciprocal translocation $(6 ; 12)(q 12 ; q 24)$. At that time he was referred because of moderate delay in psychomotor development. Now, at the age of 18 years he is a moderate mentally retarded male with normal phenotype. The parents of the patient had normal karyotypes.

\section{Cytogenetics}

Chromosomes were prepared from peripheral blood lymphocyte cultures using a modification of the synchronization method of Dutrillaux and Viegas-Pequignot ${ }^{20}$ by treatment overnight with thymidine, followed by incubation with 5-BrdU for 6 hours and ethidium bromide for one and a half hours before harvest. High-resolution banding was performed by treatment with trypsin followed by staining with Giemsa to obtain a GTG-banded pattern. 


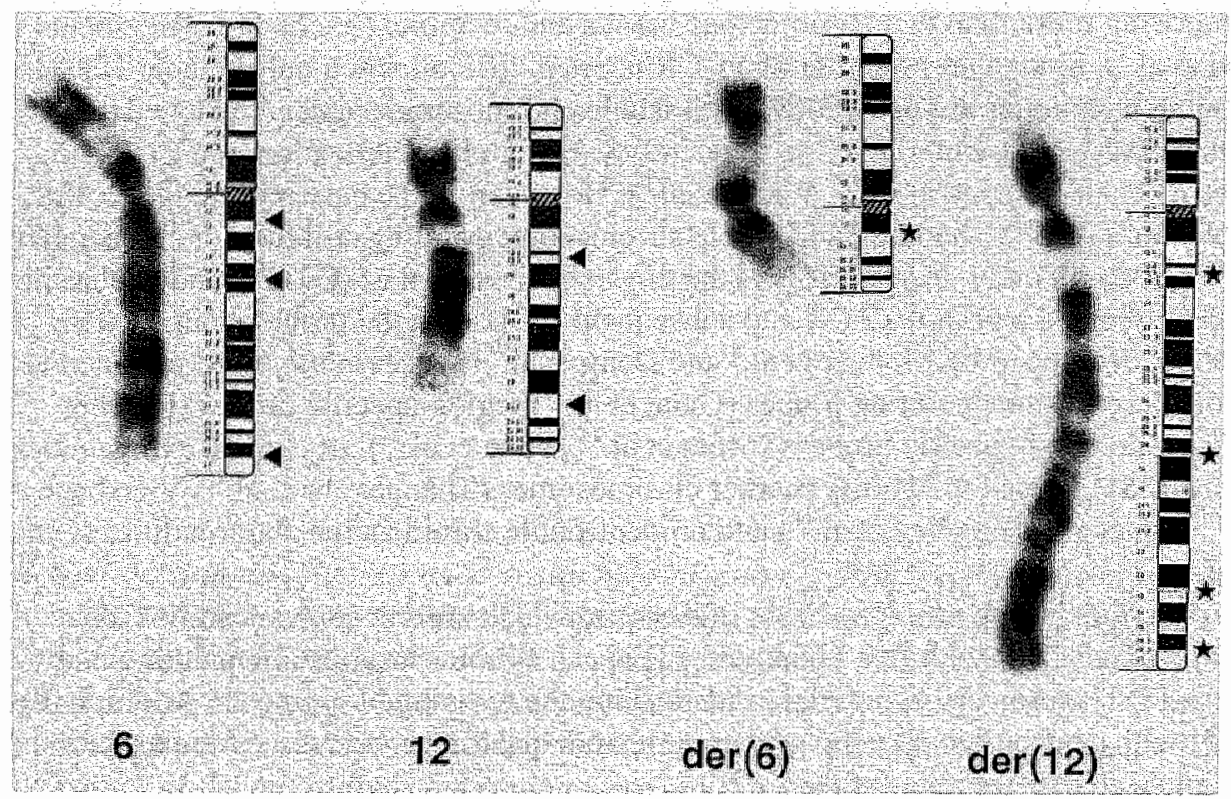

Fig. 1: Partial karyotype presenting normall GTG-banded chromosomes 6 and 12 (left) and derivative chromosomes (right). Arrows indicate breakpoints, asterisks indicate points of reunion.

\section{Microdissection and amplification of chromosomal DNA}

For microdissection, routinely fixed (methanol:acetic acid 3:1) cell suspensions stored at $-20^{\circ} \mathrm{C}$ were used to prepare metaphase spreads on coverslips. The slides were rinsed in water and stored in $98 \%$ ethanol at $-20^{\circ} \mathrm{C}$. Dissection of the distal region of the der(12) chromosome (fig. 2) was performed with glass microneedles controlled by a Narishige micromanipulator (MO-202). Before use, the needles and centrifuge tubes. were treated with UV light for $30 \mathrm{~min}$. The dissected chromosome parts were transferred to a $20 \mu \mathrm{l}$ collection drop (containing $250 \mathrm{ug} / \mathrm{ml}$ proteinase-K) in a $0.5 \mathrm{ml}$ centrifuge tube. A fresh microneedle was used for each dissection. Before DOP-PCR, the collection drop, containing ten copies of the dissected region, was incubated at $37^{\circ} \mathrm{C}$ for $30 \mathrm{~min}$ (proteinase- $\mathrm{K}$ treatment) and at $90^{\circ} \mathrm{C}$ for $10 \mathrm{~min}$ (proteinase- $\mathrm{K}$ inactivation). PCR reactions were performed following the protocol of Guan et al. ${ }^{\text {in }}$ a Biometra Personal Cycler with a heated lid. PCR products were analysed for yield and probe size (200-800 bp) on an agarose gel and stained with ethidium bromide. The PCR product was precipitated and purified with $\mathrm{NH} 4 \mathrm{Ac}(4 \mathrm{M})$ and isopropanol, washed with ethanol (70\%) and dissolved in $50 \mu \mathrm{TO}, 1 \mathrm{E}$ buffer $(10 \mathrm{mM}$ TRIS-HCl/0,1 mM Na2EDTA, pH 8.0). 

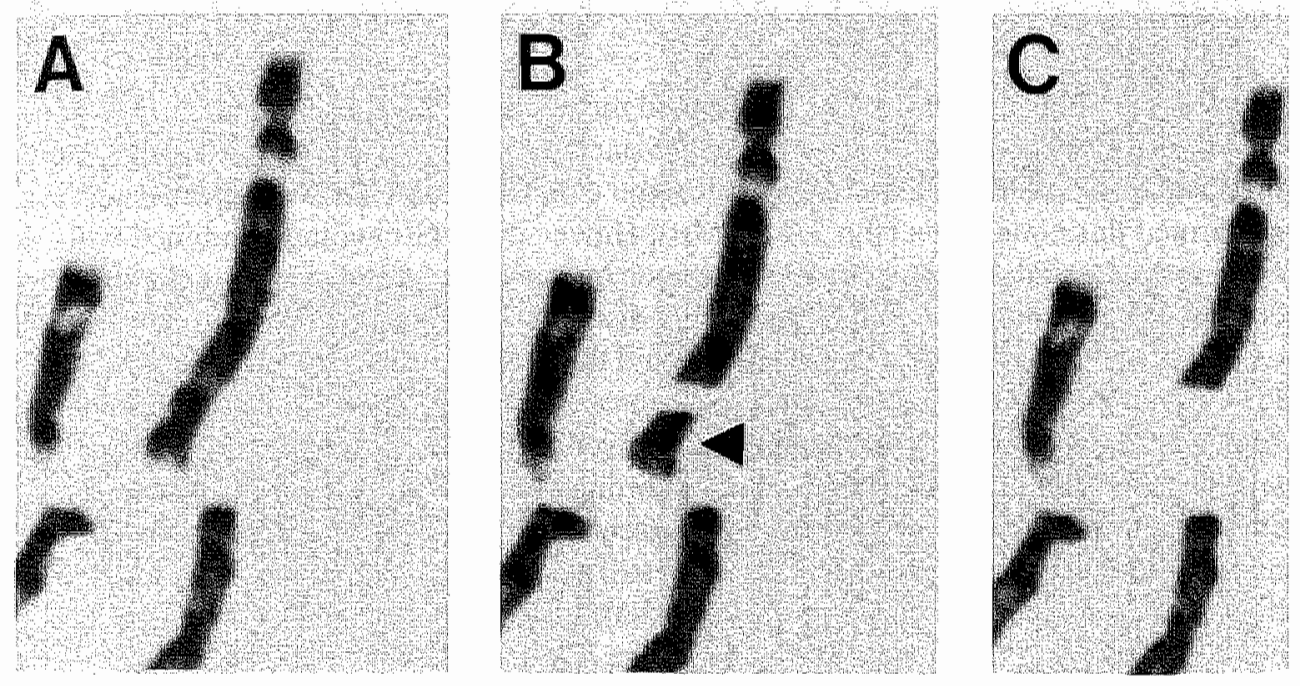

Fig. 2: Der(12) chronosome before, during and after microdissection. The arrow points to the chromosome portion that is used for DOP-PCR.

\section{Fluorescence in situ hybridization (FISH)}

In this analysis the following chromosome specific probes were used:

$\begin{array}{llll}\begin{array}{l}\text { Chromosome } \\ \text { region }\end{array} & \begin{array}{l}\text { Name of } \\ \text { probe }\end{array} & \begin{array}{l}\text { Insert } \\ (\mathrm{Kb})\end{array} & \text { Reference }\end{array}$

$\begin{array}{llll}\text { Cen. 6 } & \text { p308 } & 3.00 & \text { Jabs et al. }{ }^{2 !} \\ \text { Cen. 12 } & \text { pa12H8 } & 1.35 & \text { Looijenga et al. }^{22} \\ 6 \mathrm{q} 26 & \text { cCl6-60 } & 40 & \text { Nakamura Y, Personal Comm. } \\ 6 \mathrm{q} 27 & \text { cCl6-107 } & 40 & \text { Nakamura Y, Personal Comm. }\end{array}$


Paints specific for chromosomes 6 and 12 and labeled with biotin- 11 -dUTP were purchased (Oncor) and painting was performed according to the manufacturer's specifications. FISH with the DOP-PCR product was performed following the protocol of Pinkel et al ${ }^{23}$ with only minor modifications. The centromere-specific and bandspecific probes were labeled by nick translation with biotin-11-dATP. For FISH with these probes the protocol of Lichter et al. ${ }^{24}$ was followed. The slides were examined with a Zeiss Axiophot microscope and photographed using Scotchchrome 640 ASA colour slide film.

\section{Results}

Cytogenetic re-examination of GTG-banded metaphases revealed a complex chromosomal rearrangement of the chromosomes 6 and 12 in which at least four regions were involved (fig. 1). Painting with a chromosome 6 and a chromosome 12 specific paint confirmed this conclusion (fig. 3A and 3B). However, GTG-banding combined with chromosome painting was not sufficient to characterize the distal region of the $\operatorname{der}(12)$ chromosome completely. Ten copies of the distal region of the der(12) chromosome were collected by microdissection (fig. 2) and the probe that was generated by DOPPCR was hybridized to normal metaphase chromosomes and to metaphase chromosomes of the patient. Normal metaphases showed a signal in the region $6 \mathrm{q} 12$ to $6 \mathrm{q} 16.2$ and a second signall in the distal region of chromosome 6 (fig. 3C). On metaphase chromosomes of the patient the same fluorescence pattern as described above was seen on the normal chromosome 6 and, as expected, a fluorescent signal was seen at the distal end of the der(12) chromosome (fig. 3D). FISH with probe cCl6-60 specific for chromosome band $6 \mathrm{q} 26$ showed that the probe hybridized at the distal end of the normal chromosome 6 . In the der(12) chromosome the corresponding fluorescent spot was detected in the middle of the long arm (fig. 3E). Probe cCI6-107 specific for chromosome band $6 \mathrm{q} 27$ hybridized at the distal end of the normal chromosome 6 and at the distal end of the der(12) chromosome (fig. 3F).

Fig. 3: (A) Metaphase chromosomes of the patient after FISH with a chromosome 6 specific paint. (B) Metaphase chromosomes of the patient after FISH with a chromosome 12 specific paint. (C) Metaphase of a nomal male after IISH with the DOP-PCR probe generated from the der(12). Arrows point to the signals on the $\mathrm{q}$ arm of chromosomes 6. (D) Metaphase of the patient after FISH with the DOP-PCR probe generated from the der(12) chromosome. Signals are on the $q$ arm of chromosome 6 and on the $\mathrm{q}$ arm of the der(12) chromosome. (E) Metaphase of the patient after ISH with centromere probe p308 (6) and probe pa12H8 (12) together with probe cC16-60 specifie for chromosome band $6 q 26$. Arrows point to the signals on the $\mathrm{q}$ arm of chromosome 6 and the $\mathrm{q}$ arm of the der(12) chromosome. (F) Sane as fig. 3E with probe cC16-107 specific for chromosome band $6 q 27$. 

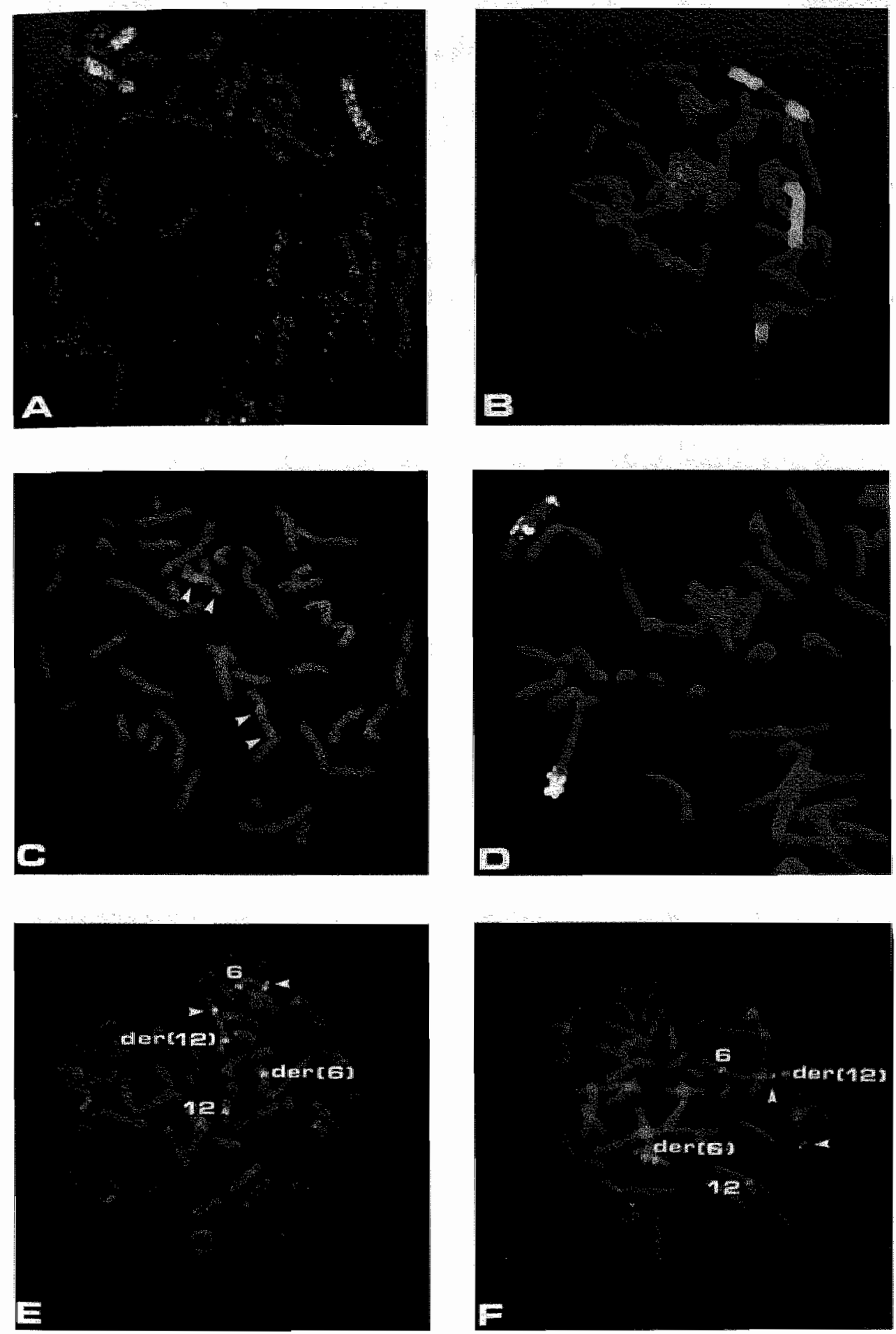


\section{Discussín}

High-resolution GTG-banding is usually sufficient to identify chromosome translocations. However, for the clarification of complex chromosome rearrangements, FISH with chromosome painting probes is nowadays almost indispensable. At the moment painting probes are available for all chromosomes and their use has led to a reinterpretation of the karyotype in at least one other previously reported case with a CCR (Batista et al..$^{6}$ ). In the present case, the combined data of GTG-banding and chromosome painting still left some doubts about the structure of the der(12) chromosome. Microdissection has provided a means for characterization of chromosome bands and chromosome regions. Several laboratories have previously utilized microdissection of GTG-banded human metaphase chromosomes to generate regionspecific libraries. The first studies used restriction endonuclease digestion and DNA ligation steps (Johnson et al. ${ }^{25}$; Lüdecke et al. ${ }^{26}$; Senger et al. ${ }^{27}$; Davis et al ${ }^{28}$; Lengauer et al $\left.{ }^{29}\right)$. Later, Meltzer et al $^{8}{ }^{8}$ developed a technique that eliminated the microchemistry procedure by making use of a DOP-PCR and cloning procedure. Recently, Guan et al..$^{10,11,12}$ used DOP-PCR probes generated from microdissected GTG-banded chromosomes for chromosome (region) painting.

In our case, whole chromosome painting disclosed that at least 6 regions (and 4 breakpoints) were involved in this complex rearrangement. However, micro-FISH of the distal region of the der(12) chromosome showed that this region originates from two different segments of chromosome 6 namely $6 \mathrm{q} 12-6 \mathrm{q} 16.2$ together with a distal region of $6 \mathrm{q}$ thus disclosing a fifth breakpoint. FISH with probes specific for chromosome bands $6 \mathrm{q} 26$ and $6 \mathrm{q} 27$ further characterized this fifth breakpoint in chromosome 6 between these bands. The patient's karyotype is: $46, \mathrm{XY}, \mathrm{t}(6 ; 12)(6 \mathrm{pter}->6 \mathrm{q} 12:: 12 \mathrm{q} 24.1$ $\rightarrow>12$ qter; 12pter-> 12q13.3::6q16.2->6q26::12q13.3->12q24.1::6q12->6q16.2::6q26 $\rightarrow$ 6qter). As loss or gain of chromosomal material was not detected, the mental. retardation of our patient can best be explained by a small submicroscopic deletion or by disruption of a gene or regulatory sequence caused by one (or more) of the five breakpoints. This assumption is supported by the increased risk on mental retardation and phenotypic abnormalities in carriers of apparently balanced de novo translocations (Warburton et al. ${ }^{30}$ ) or de novo CCRs (Kousseff et al. ${ }^{31}$; Kausch et al. ${ }^{32}$ ) when compared with famillial cases.

In summary, the use of chromosome painting, micro-FISH and FISH with bandspecific probes showed a CCR of the chromosomes 6 and 12 in which five breakpoints were inwolved. The application of these techniques provides a powerful tool in the characterization of constitutional and acquired complex structural aberrations. Furthermore, the results of our study show that the generated DOP-PCR probe contains DNA sequences that span a breakpoint. Microdissection in combination with DOP-PCR and subsequent cloning will enable the isolation of sequences from translocation breakpoints associated with genetic diseases or specific forms of cancer that can be used in metaphase and interphase cytogenetics and in genome analysis. 


\section{References}

1-Pai GS, Thomas GH, Mahoney W, Migeon BR: Complex chromosome rearrangenents. Clinic Genet 18:436-444 (1980).

2-Pinkel D, Straume T, Gray JW: Cytogenetic analysis using quantitative, high sensitive fluorescence hybridization. Proc Natl Acad Sci USA 83:2934-2938 (1986).

3-Lichter P, Cremer T, Borden J, Manuelidis L, Ward DC: Delineation of individual human chromosomes in metaphase and interphase cells by in situ suppression hybridization using recombinant DNA libraries. Hum Genet 88:224-234 (1988).

4-Verma RS, Conte RA, Macera MJ, Khan ASSI, Hebi S, Masoud AA, Al Zaman A. Al Bader M: Molecular characterization of a complex translocation in a newborn child. Am J Med Genet 46:104108 (1993).

5- Batista DAS, Tuck-Muller CM, Martinez JE, Kearns WG, Pearson PL, Stetten G: A complex chromosomal rearrangement detected prenatally and studied by fluorescence in situ hybridization. Hum Genet 92:117-121 (1993).

6- Batista DAS, Pai GS, Stetten G: Molecular analysis of a complex chromosomal rearrangement and a review of familial cases. Am J Med Genet 53:255-263 (1994),

7-Wang YT, Bajalica S, Han FY, Wang ZC, Bui TH, Xie YG: Direct and inverted reciprocal insertions between chromosomes 7 and 14 in a woman with recurrent miscarriages. Am J Med Genet 52:349-351 (1994).

8-Meltzer PS, Guan XY, Burgess A, Trent J: Rapid generation of region specific probes by chromosome microdissection and their application. Nature Genet 1:24-28 (1992).

9- Deng HX, Yoshiura KI, Dirks RW, Harada N, Hirota T, Tsukamoto K, Jinno Y, Niikawa N: Chromosome-band-specific-painting: chromosome in situs suppression hybridization using PCR products from a microdissected chromosome band as a probe tool. Hum Genet 89:13-17 (1992). 10- Guan XY, Meltzer PS, Trent JM: Rapid generation of whole chromosome painting probes (WCPs) by chromosome microdissection. Genomics 22:101-107 (1994).

11 - Guan XY, Meltzer PS, Cao J, Trent JM: Rapid generation of region-specific genomic clones by chromosome microdissection: isolation of DNA from a region frequently deleted in malignant melanoma. Genomics 14:680-684 (1992).

12-Guan XY, Meltzer PS, Burgess AC, Trent JM: Coverage of chromosome 6 by chromosome microdissection: generation of 14 subregion-specific probes. Hum Genet 95:637-640 (1995)

13-Hirota T, Tsukamoto K, Deng HX, Yoshiura KI, Ohta T, Tohma T, Kibe T, Harada N, Jinno Y, Niikawa N: Microdissection of human chromosomal regions $8 \mathrm{q} 23.3 \mathrm{-q} 24.11$ and $2 \mathrm{q} 33$-qter: Construction of DNA libraries and isolation of their clones. Genomics 13:349-154 (1992).

14- Guan XY, Trent JM, Meltzer PS: Generation of band-specific painting probes from a single microdissected chromosome. Hum Mol Genet 8:111.7-1.121 (1993).

15-Thangavelu M, Pergament E, Espinosa R, Bohlander SK: Characterization of marker chromosomes by microdissection and fluorescence in situ hybridization. Prenat Diagn 14:583 588 (1994). 16-Viersbach R, Schwanitz G, Nothen M: Delineation of marker chromosomes by reverse chromosome painting using only a small number of DOP-PCR amplified microdissected chromosomes. Hum Genet 93:663-667 (1994).

17-Sun Y, Rubinstein J, Soukop S, Palmer CG: Marker chromosome 21 identified by microdissection and FISH. Am $₫$ Med Genet 56:151-54 (1995).

18- Engelen JJM, Loots WJG, Motoh PCC, Moog U, Hamers GJH, Geraedts JPM: Marker chromosome identification by micro-FISH. Clin Genet 46:242-248 (1996).

19.-Ohta T, Tohma T, Soejima H, Fukushima Y, Nagai T, Yoshiura K, Jinno $Y$, Niikawa N: The origin of cytogenetically unidentifiable chromosome abnormalities: six cases ascertained by targeted chromosome-band painting. Hum Genet 92:1-5 (1993).

20-Dutrillaux B, Viegas-Pequignot $\mathrm{E}$ : High resolution $\mathrm{R}$ - and $\mathrm{G}$-banding in the same preparation. Hum Genet 57:93-95 (1981).

21-Jabs EW, Wolf SF, Migeon BR: Characterization of a cloned DNA sequence that is present at centromeres of all human autosomes and the $\mathrm{X}$-chromosome and shows polymorphic variation. Proc 
Natl Acad Sci USA 81:4884-8 (1984).

22-Looijenga LH, Smit VT, Wessels JW, Mollevanger $\mathrm{P}$, Oosterhuis JW, Cornelisse CJ, Devilee P: Localization and polymorphism of a chromosome 12 specific alpha satellite DNA sequence.

Cytogenet Cell Genet $53: 216-218(1990)$.

23-Pinkel D, Landegent J, Collins $C$, Fuscoe J, Segraves $R$, Lucas J, Gray J Fluorescence in situ Gybridization with chromosome-specific libraries: detection of trisomie 21 and translocation of chromosome 4. Proc Natl Acad. Sci. USA 85:9138-9142 (1988).

24-Lichter $\mathrm{P}$, Tang $\mathrm{CC}_{4}$ Call $\mathrm{K}$, Hermanson $\mathrm{G}$, Evans HJ, Housman $\mathrm{D}$, Ward DC: High resolution mapping of human chromosome 11 by in situ hybridization with cosmid clones. Science 247:64-69 (1990).

25.Johnson DH: Molecular cloning of DNA from specific chromosomal regions by microdissection and sequence-independent amplification of DNA. Genomics 6:243-251 (1989).

26-Ludecke HJ, Senger G, Claussen U, Horsthemke B: Cloning defined regions of human genome by microdissection of banded chromosomes and enzymatic amplification. Nature 338:348-250 (1989). 27. Senger G, Ludecke HJ, Horsthemke B, Claussen U: Microdissection of banded human chromosomes. Hum Genet 84:507-511 (1990).

28- Davis LM, Senger G, Ludecke HJ, Claussen U, Horsthemke B, Zhang SS, Metzroth B,

Hohenfellner $\mathrm{K}$, Zable $\mathrm{B}$, Shows TB: Somatic cell hybrid and long-range physical mapping of $11 \mathrm{p} 13$ microdissected genomic clones. Proc Natl Acad Sci USA 87:7005-7009 (1990).

29-Lengauer C, Eckelt A, Weith A, Endlich N, Ponelies N, Lichter P, Gruelich KO, Cremer T:

Painting of defined chromasomal regions by in situ suppression hybridization of libraries from lasermicrodissected chromosomes. Cytogenet Cell Genet 56:27-30 (1991).

30.-Warburton D: De novo balanced chromosome rearrangements and extra marker chromosomes identified at prenatal diagnosis. Am J Hum Genet 49:995-1013 (1991).

31-Kousseff BG, Nichols P, Essig YP, Miller K, Weiss A, Tedesco TA: Complex chromosome rearrangements and congenital anomalies. Am J Med Genet 26:771-782 (1987).

32-Kausch $\mathrm{K}$, Haaf T, Kohler $\mathrm{H}$, Schmid $\mathrm{M}$ : Complex chromosomal rearrangement in a woman with multiple miscarriages. Am J Med Genet 31:415-420 (1988). 


\section{APPLICATION OF MICRO-FISH TO DELINEATE DELETIONS.}

John J.M. Engelen, Jozefa C.M. Albrechts, Wil J.G. Loots, Bertien H.T.M. Hollanders-Crombach, Guus J.H. Hamers and Joep P.M. Geraedts.

Department of Molecular Cell Biology and Genetics, University of Maastricht, Maastricht, The Netherlands.

Published in:

Cytogenetics and Cell Genetics 75:167-171 (1996). 
Microdissection in combination with fluorescence in situ hybridization (micro-FISH) is used to visualize deletions in rearranged chromosomes and in a de novo translocation. In each experiment five copies of a structurally aberrant chromosome or of the two chromosomes involved in a de novo translocation were isolated by micradissection and amplified using DOP-PCR. The PCR products were then used as probes for fluorescence in situ hybridization (FISH) to metaphase chromosomes of the patients. After reverse chromosome painting, the structurally aberrant chromosomes were completely painted and the region deleted in the aberrant chromosomes was visible in the normal chromosomes. The smallest deletion that could be demonstrated this way was a microdeletion of approximately $6 \times 10^{6} \mathrm{bp}$ which is frequently reported in Angelman and Prader-Willi syndromes. 


\section{Introduction}

In the past decade fluorescence in situ hybridization techniques utilizing chromosomespecific, centromere-specific and numerous chromosome band-specific probes have become a part of routine cytogenetic analysis for studying chromosomal rearrangements (Lichter et al. ; Pinkel et al. ${ }^{2}$ ). However, these techniques have a disadvantage in that probes and chromosome paints to be used must be tested empirically when cytogenetically unidentifiable chromosome abnormalities, such as marker chromosomes and unbalanced de novo translocations are involved. Meltzer et al ${ }^{3}$ and Deng et al. ${ }^{4}$ introduced a technique based on the physical dissection of GTG-banded chromosomes followed by a degenerate oligonucleotide primed-polymerase chain reaction (DOP-PCR) and subsequent FISH using the total PCR product as a probe (micro-FISH), which overcomes this limitation. Micro-FISH has been applied in clinical cytogenetics to identify marker chromosomes (Thangavelu et al. ${ }^{s}$, Viersbach et al. ${ }^{6}$; Sun et al. ${ }^{7}$; Muller-Navia et al. ${ }^{8}$; Engelen et al. ${ }^{9}$ ), unbalanced translocations (Ohta et al. ${ }^{10}$ ) and complex chromosome rearrangements (Zhang et al. ${ }^{11}$; Engelen et al. ${ }^{12}$ ). In this report, the results of using microdissection combined with DOP-PCR and reverse chromosome painting (Carter et al. ${ }^{13}$ ) are presented. Application of microFISH made it possible to demonstrate the loss of chromosomal material in a de novo translocation and to characterize deletions in aberrant chromosomes more precisely.

\section{Material and methods}

\section{Cases}

Case 1 is a newborn girl referred for cytogenetic examination because of blepharophimosis, microphthalmia, low implanted ears, enlarged ventricles, long fingers and clinodactylia of the left digits III and IV.

Case 2 is an obese 3 year-old boy with psychomotor retardation, strabismus, pes equinovarus and facial anomalies.

Case 3, a girl, was referred at the age of 8 mo for diagnostic examination because of developmental retardation, generalised hypotonia, protruding tongue and at times inexpedient motoric anxiety.

\section{Preparation of metaphase chromosomes}

Chromosomes were prepared from peripheral blood lymphocytes using the synchronization method of Dutrillaux and Viegas-Pequignot ${ }^{14}$ with minor modifications. For microdissection routinely fixed (methanol:acetic acid 3:1) cell suspensions stored at $20^{\circ} \mathrm{C}$ were used to prepare metaphase spreads on $45 \times 65 \mathrm{~mm}$ coverslips. The slides were rinsed in water and stored in $98 \%$ ethanol at $-20{ }^{\circ} \mathrm{C}$. GTG-banding with trypsinGiemsa was performed prior to microdissection. 


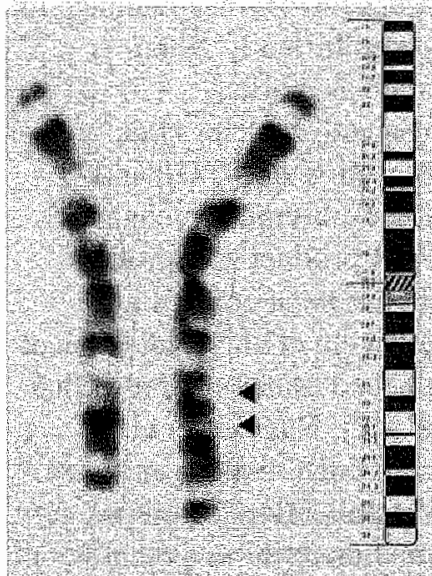

(4)

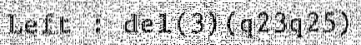

Whet hoinat clunosorie?

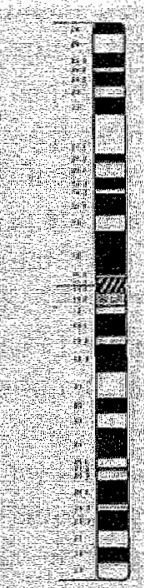

0456

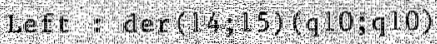

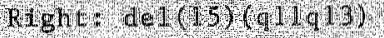

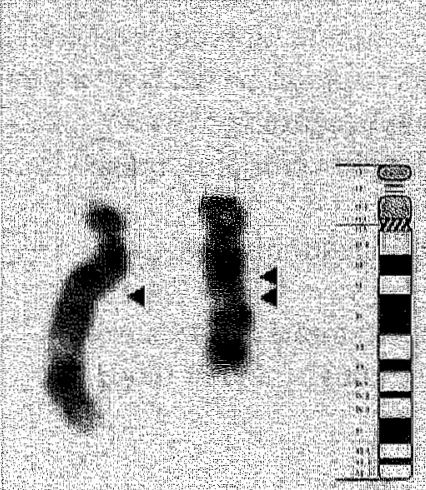

West 2

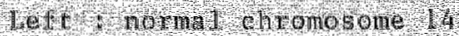

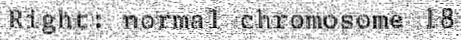
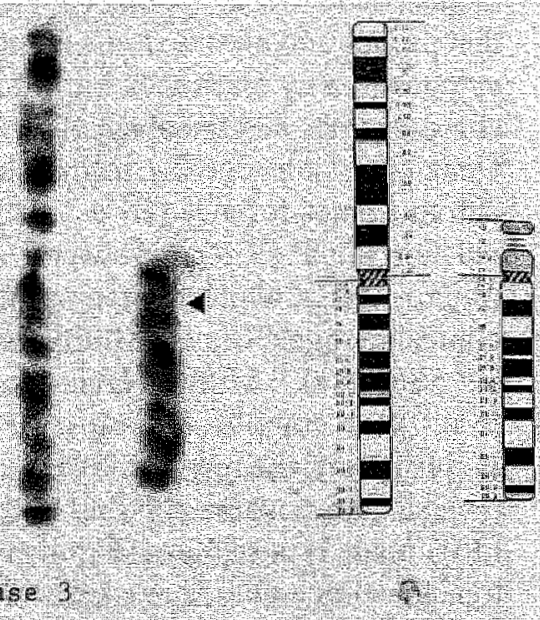$$
\text { +1: }
$$$$
1+
$$ 


\section{Microdissection and amplification of chromosomal DNA}

Microdissection was performed with glass microneedles controlled by a Narishige micromanipulator (MO-202). Before they were used, microneedles and microcentrifuge tubes were exposed to ultra violet light for $30 \mathrm{~min}$. Five copies of the structurally aberrant chromosomes of case 1 and 3 and the two chromosomes involved in the de novo translocation of case 2 were dissected. The chromosomes were transferred to a 20 $\mu \mathrm{l}$ collection drop (containing $250 \mu \mathrm{g} / \mathrm{ml}$ proteinase- $\mathrm{K}$ ) in a $0.5 \mathrm{ml}$ thin walled microcentrifuge tube. A fresh microneedle was used for each chromosome. Before DOP-PCR the collection drop was incubated at $37^{\circ} \mathrm{C}$ for $30 \mathrm{~min}$ (proteinase- $\mathrm{K}$ treatment) and at $90^{\circ} \mathrm{C}$ for $10 \mathrm{~min}$ (proteinase- $\mathrm{K}$ inactivation). The universal primer $5^{\prime C C G A C T C G A G N N N N N N A T G T G G ~ 3 " ~ w a s ~ u s e d ~ i n ~ t h e ~ D O P-P C R ~ a s ~ s u g g e s t e d ~ b y ~}$ Telenius et al. ${ }^{15}$. The PCR buffer contained $100 \mu \mathrm{M}$ of each dNTP, $2.5 \mathrm{mM} \mathrm{MgCl}$, $50 \mathrm{mM} \mathrm{KCl}, 10 \mathrm{mM}$ Tris- $\mathrm{HCl} \mathrm{pH} 8.3,0.1 \mathrm{mg} / \mathrm{ml}$ gelatine, $0.1 \%$ (v/v) Nonidet P-40, $0.1 \%(\mathrm{v} / \mathrm{v})$ Tween-20, $1.5 \mu \mathrm{M}$ universal primer and $0.5 \mathrm{U}$ super Taq DNA polymerase (HT Biotechnology) in a final volume of $50 \mu \mathrm{l}$. For initial denaturation the mixture was heated to $93^{\circ} \mathrm{C}$ for $3 \mathrm{~min}$, followed by 8 cycles of 1 min at $94^{\circ} \mathrm{C}, 1 \mathrm{~min}$ at $30^{\circ} \mathrm{C}, 1$ min at $45^{\circ} \mathrm{C}$ and 3 min at $72{ }^{\circ} \mathrm{C}$ and by 28 cycles of 1 min at $94^{\circ} \mathrm{C}, 1$ min at $56^{\circ} \mathrm{C}, 3$ min at $72{ }^{\circ} \mathrm{C}$ with a final extension step at $72{ }^{\circ} \mathrm{C}$ for $10 \mathrm{~min}$. The DOP-PCR experiments contained a negative control consisting of all PCR components except microdissected DNA and a positive control with $25 \mathrm{pg}$ total human DNA. PCR reactions were performed in a Biometra personal cycler with a heated lid. PCR products were stained with ethidium bromide and analysed for yield and probe size (200-900 base pairs) on an agarose gel. Experiments were proceeded only if DNA synthesis was not apparent in the negative control. The PCR product was precipitated and purified with $4 \mathrm{M}$ ammonium acetate and isopropanol, washed with ethanol (70\%) and dissolved in $50 \mu \mathrm{T}$ T, $1 \mathrm{E}$ buffer (10 mM TRIS-HCl/0,1 mM Na2EDTA, pH 8.0).

\section{Fluorescence in situ hybridization (FISH).}

PCR products were labeled by nick-translation with biotin-14-dATP (BioNick labeling system (Gibco BRL)). Metaphase spreads for FISH were prepared from PHA-stimulated lymphocytes using standard methanol: acetic acid (3:1) fixation. In situ hybridization was performed following the protocol by Guan et al. ${ }^{16}$ with only minor modifications. Briefly, for hybridization, $200 \mathrm{ng}$ probe was used in $10 \mu 1$ hybridization mixture containing $50 \%$ formamide, $2 \times \mathrm{SSC}, 10 \%$ dextran sulphate, $50 \mathrm{mM}$ phosphate, $20 \mu \mathrm{g}$ human Cot $1 \mathrm{DNA}$ (Gibco BRL). Probe and Cot DNA were denaturated at $70^{\circ} \mathrm{C}$ for $5 \mathrm{~min}$ and reannealed at $37^{\circ} \mathrm{C}$ for $90 \mathrm{~min}$. Slides were denaturated in $70 \%$ formamide, $2 \mathrm{xSSC}(\mathrm{pH} 7.0)$ at $70^{\circ} \mathrm{C}$ for $3 \mathrm{~min}$, delhydrated, and hybridized overnight in a moist chamber at $37^{\circ} \mathrm{C}$ with the probe. Slides were then washed four times in $2 \times \mathrm{SSC}$ ( $\mathrm{pH} 7.0$ ) at $45^{\circ} \mathrm{C}$ for $5 \mathrm{~min}$, followed by one wash in PN buffer [0.1 M sodium phosphate, $0.1 \%(\mathrm{v} / \mathrm{v})$ Nonidet $\mathrm{P}-40, \mathrm{pH} 8.0 \rrbracket$ at $45^{\circ} \mathrm{C}$ for $10 \mathrm{~min}$. The hybridization signal was detected by three layers of fluorescein-avidin DCS (Vector) amplified by two layers of biotinylated anti-avidin D (Vector), followed by two washes with $4 \times$ SSC, $0.5 \%$ Tween and one wash with PBS. Slides were dehydrated and counterstained with DAPI/PI in antifade solution. Analysis was carried out using a Zeiss Axiophot 
microscope and photographs taken with Scotch chrome 640 ASA colour slide film.

\section{Results}

In case 1, analysis of $25 \mathrm{G}$-banded high-resolution metaphases disclosed a deletion of either region $3 q 23-3 q 25$ or $3 q 25-3 q 26.2$ (fig. 1A). After microdissection and reverse chromosome painting with the DOP-PCR probe generated from the aberrant chromosome 3, the deleted chromosome was completely painted in metaphases of the patient but the normal chromosome 3 showed no hybridization signal in region $3 q 23-3 q 25$ (Fig. 2A). The parents had normal karyotypes.

In case 2 examination of $17 \mathrm{G}$-banded high-resolution metaphases revealed a translocation between the long arms of chromosomes 14 and 18 along with a deletion of either band $14 \mathrm{q} 23$ or band $18 \mathrm{q} 12.3$ (fig. 1C and ID). FISH with paints specific for chromosome 14 and 18 indicated that the missing chromosome band was not translocated to any other chromosome (not shown). After hybridization of the probe generated by DOP-PCR of the microdissected derivative chromosomes 14 and 18 to metaphases of the patient, the der(14), der(18) and the normal chromosome 14 were completely painted. However, the normal chromosome 18 did not display a signal in band 18q12.3 (fig. 2B). The parents had normal karyotypes.

In case 3 examination of 25 high-resolution G-banded metaphases revealed a Robertsonian translocation between the chromosomes 14 and 15 and a deletion of region $15 \mathrm{q} 11 \mathrm{-q} 13$ in the chromosome 15 not involved in the translocation (fig. 1B). Analysis of the father's chromosomes showed that he was a carrier of the translocation, whereas the mother had a normal $46, \mathrm{XX}$ karyotype. Following reverse chromosome painting with the generated DOP-PCR probe, the deleted chromosome 15 was completely painted and band $15 \mathrm{q} 12$ in the chromosome 15 involved in the Robertsonian translocation (fig. 2C) displayed no fluorescent signal.

TABLE 1: CALCULATION OF THE AMOUNT OF MISSING BASE PAIRS IN THE ABERRANT CHROMOSOMES

$\begin{array}{lcccc} & \begin{array}{c}\text { Rel. length } \\ \text { Chromosome 3 }\end{array} & \begin{array}{c}\text { Base pairs } \\ 2.06\end{array} & \begin{array}{c}\text { Deletion } \\ 212 \times 10^{6}\end{array} & \text { Base pairs } \\ \begin{array}{l}\text { Case 1 } \\ \text { Chromosome 15 }\end{array} & 3.36 & 100 \times 10^{6} & 10.25 \% & 22 \times 10^{6} \\ \begin{array}{l}\text { Case 3 } \\ \text { Chromosome 18 }\end{array} & 2.76 & 83 \times 10^{6} & 6.0 \% & 6 \times 10^{6} \\ \text { Case 2 } & & & 10.8 \% & 9 \times 10^{6}\end{array}$

I: Relative length in percentage of the total haploid autosome length (ISCN, 1985) ${ }^{26}$.

${ }^{2}:$ Calculated deleted region expressed as a percentage of the entire length of the chromosome involved. 


\section{Discussion}

In this study we demonstrate that a deleted region in an aberrant chromosome can be detected by microdissection of the aberrant chromosome with subsequent DOP.PCR and in situ hybridization of the generated probe to metaphase cells derived from the patient. The deleted region is immediately recognizable in the microscope owing to the lack of a fluorescent signal in the normal chromosome.

Microdissection of G-banded human metaphase chromosomes has been used by several laboratories to generate region-specific libraries. Restriction endonuclease digestion and DNA ligation steps were used by Johnson et al. ${ }^{17}$, Lüdecke et al. ${ }^{18}$, Davis et al. ${ }^{19}$ and Lengauer et al. ${ }^{20}$ in their studies. Meltzer et al. ${ }^{3}$ and Deng et al. ${ }^{4}$ developed a technique that eliminated the microchemical procedure using the PCR product for cloning. Subsequently, Guan et al. ${ }^{21-22}$ used DOP-PCR probes generated from microdissected chromosomal material for chromosome (region) painting. Micro-FISH is employed today in clinical cytogenetics laboratories to characterize unidentifiable chromosome abnormalities, such as marker chromosomes and complex chromosomal rearrangements.

In this study micro-FISH was applied to demonstrate the loss of chromosomal material in aberrant chromosomes and to delineate the deleted region more precisely. The complete painting of the derivative chromosomes in the experiments provides evidence that the chromosomes indeed had been microdissected and multiplied by DOP-PCR completely. In case 1 , cytogenetic analysis revealed a deletion in the long arm of one of the chromosomes 3 ; however, it could not be determined whether the chromosome region involved was 3 q23-q25 or 3q25-q26.2. Micro-FISH allowed us to identify the deleted region as $3 \mathrm{q} 23-\mathrm{q} 25$ based on the lack of a fluorescent signal in this region in the normal chromosome 3 . Therefore, in combination with the G-banding results, the consensus karyotype for case 1 would be: $46, \mathrm{XX}$,del(3)(q23q25). This is in accordance with the clinical picture presented by the patient since blepharophimosis in combination with ptosis and epicanthus inversus is frequently reported in patients with a deletion or break in 3 q23 (Jewett et al. ${ }^{24}$; Small et al. ${ }^{25}$ ).

Case 2 is a patient with a de novo translocation involving chromosomes 14 and 18 along with a deletion of either chromosome band $14 \mathrm{q} 23$ or $18 \mathrm{q} 12.3$. Hybridization of the DOP-PCR probe to metaphase chromosome preparations derived from the patient showed a lack of fluorescence in the normal chromosome at band $18 \mathrm{q} 12.3$ indicating that he has an unbalanced $46, \mathrm{XY}, \mathrm{t}(14 ; 18)(14 \mathrm{pter}->14 \mathrm{q} 22:: 18 \mathrm{q} 21.1->18 \mathrm{qter} ; 18 \mathrm{pter}$ $\rightarrow 18 \mathrm{q} 12.2: 14 \mathrm{q} 23->14 \mathrm{qter}$ ) karyotype in which band $18 \mathrm{q} 12.3$ is deleted.

Case 3 is a girl with a Robertsonian translocation, der(14;15)(q10;q10) and a deletion of region 15q11-q13 in the second chromosome 15 . Owing to the involvement of the normal chromosome 15 in the translocation, the deleted chromosome 15 could be traced without confusion. This patient, with a microdeletion of band $15 \mathrm{q} 12$ that is frequently reported in patients with Prader-Willi or Angelman syndrome, was included in this study to test whether this new application of micro-FISH is powerful enough to detect microdeletions.

The haploid human genome comprises $3 \times 10^{9}$ base pairs and $3.36 \%$ of them are present in one chromosome 15 (ISCN, 1985) ${ }^{26}$. Chromosome band $15 \mathrm{q} 12$ constitutes 

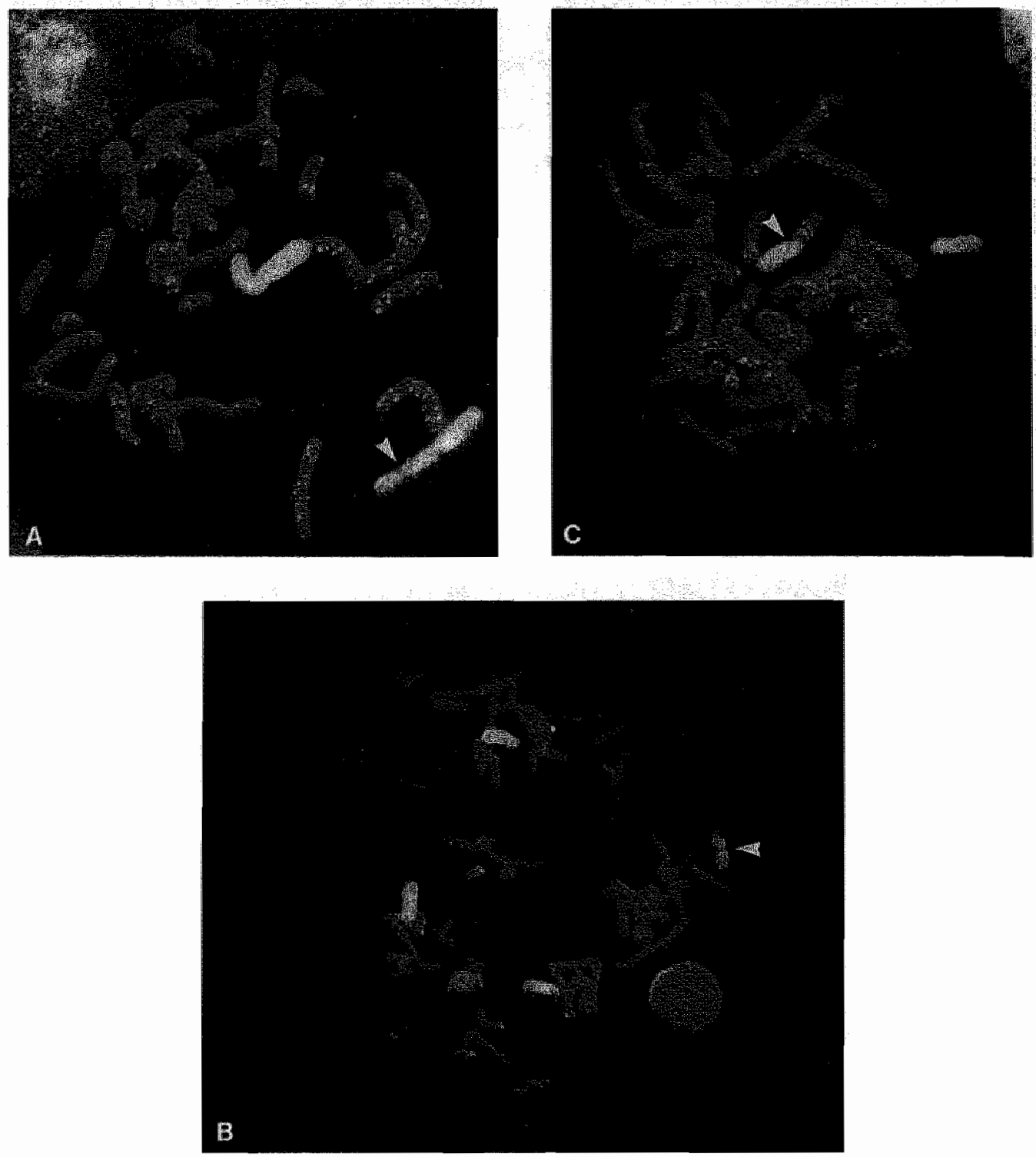

Figure 2: A: Metaphase cell of case 1 after FISH with the DOP-PCR probe generated from the aberrant chromosome 3. B: Metaphase cell of case 2 after FISH with the DOP-PCR probe generated from both chromosomes involved in the $14 \mathrm{q} ; 18 \mathrm{q}$ translocation. C: Metaphase cell of case 3 after FISH with the DOP-PCR probe generated from the aberrant chromosome 15. Arrows indicate the "deleted regions". 
about $6 \%$ of chromosome 15 ; consequently, the deletion comprises about $6 \times 10^{6}$ base pairs (table 1). After reverse chromosome painting with the DOP-PCR probe, the deletion was clearly recognizable owing to the lack of fluorescent signal in the corresponding region of the translocation chromosome. Indeed, when chromosome quality is poor, as is true of many hematological and solid tumors, deletions can be characterized more precisely through hybridization of the generated DOP-PCR probe to high-resolution chromosomes of a control individual.

This paper has shown the power of micro-FISH as a tool for the characterization of chromosome abnormalities. The primary advantages of this technique lie in its simplicity and speed. The whole process of microdissection, DOP.PCR, probe labeling and reverse painting can be completed within three days. Furthermore, although probes of virtually all chromosome bands exist and deletion affirmation is possible with bandspecific cosmids, micro-FISH has the advantage that laboratories do not have to possess a gigantic stock of probes. The colour images for this report were made with a Zeiss Axiophot microscope and illustrate that this technique produces perfectly adequate results without image enhancement. 


\section{References}

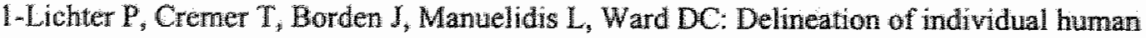
chromosomes in metaphase and interphase cells by in situ suppression hybridization using recombinant DNA libranies, Hum Genet 88:224-234 (1988).

2 Pinkel D, Landegent J, Collins C, Fuscoe J, Segraves R, Lucas I, Gray Ji Fluorescence in situ hybridization with chromosome specific libraries: detection of trisomie 21 and translocation of chromosome 4. Proc Natl Acad Sci USA 85: 138-9142 (1988).

3-Melizer PS, Guan XY, Burgess A, Trent J: Rapid generation of region specific probes by chromosome microdissection and their application. Nature Genet 1:24-28 (1992).

4 Deng IIX, Yoshiura Kl, Dirks RW, Harada N, Hirota T, Tsukamoto K, Jinno Y, Niikawa N: Chromosome-band-specific-painting chromosome in situ suppression hybridization using PCR products from a microdissected chromosome band as a probe tool. Hum Genet 89:13-17 (1992).

5-Thangavelu $M$, Pergament $\mathrm{E}$, Espinosa $\mathrm{R}$, Bohlander $\mathrm{SK}$ : Characterization of marker chromosomes by microdissection and fluorescence in situ hybridization. Prenat Diagn 14:583-58: (1994).

6-Viersbach $\mathrm{R}_{\text {; }}$ Schwanitz $\mathrm{G}$, Nothen $\mathrm{M}$ : Delineation of marker chromosomes by reverse chromosome painting using only a small number of DOP-PCR amplified microdissected chromosomes. Hum Genet 93:663-667 (1994).

7 Sun Y, Rubinstein J, Soukop S, Palmer CG: Marker chromosome 21 identified by microdissection and FISH, Am J Med Genet 56:151-54 (1995).

8.Muller Navia J, Nebel A, Schleiermacher E: Complete and precise characterization of marker chromosomes by application of microdissection in prenatal diagnosis. Hum Genet 96:661-667 (1995)

9- Engelen JJM, Loots WJG, Motoh PCC, Moog U, Hamers AJH, Geraedts JPM: Marker chromosome identification by Micro-FISH. Clin Genet 49:242-248 (1996).

10-Ohta T, Tohma T, Soejima H, Fukushima Y, Nagai T, Yoshiura K, Jinno $Y$, Niikawa $N$ : The origin of cytogenetically unidentifiable chromosome abnormalities: six cases ascertained by targeted. chromosome-band painting. Hum Genet 92:1-5 (1993).

11-Zhang $\mathrm{J}_{\text {, Meltzer }}$, Jenkins $\mathrm{R}$, Guan XY, Trent $\mathrm{J}$ : Application of chromosome microdissection probes for elucidation of BCR-ABL fusion and variant Philadelphia chromosome translocations in chronic myelogenous leukemia. Blood 12: 3365-3371 (1993).

12- Engelen JIM, Loots WJG, Albrechts JCM, Motoh PCC, Fryns JP, Hamers AJH, Geraedts JPM:

Disclosure of five breakpoints in complex chromosome rearrangement (CCR) by microdissection and FISH. J Med Genet 33:562-566 (1996).

13. Carter NP, Ferguson-Smith MA, Peryman MT, Telenios H, Pelmear AH, Leversina MA, Glancy

MT, Wood SL, Cook K, Dyson HM, Ferguson-Smith ME, Willatt LR: Reverse chromosome painting: a nethod for the rapid analysis of aberrant chromosomes in clinical cytogenetics. J Med Genet 29:299.307 (1992).

14- Dutrillaux $B$, Viegas-Pequignot E: High resolution R- and G-banding in the same preparation. Hum Genet 57:93-91 (1981).

15-Telenius $\mathrm{H}_{\mathrm{s}}$ Carter NP, Bebb $\mathrm{CE}$, Nordenskjold M, Ponder BA, Tunnacliffe A: Degenerate oligonucleotide-primed PCR: general amplification of target. DNA by a single degenerate primer. Genomics 13:718-725 (1992).

16-Guan XY, Cargille CB, Anzick SL, Thompson FH, Meltzer PS, Bittner ML, Taetle R, McGill JR, Trent JM: Chromosome microdissection identifies cryptic sites of DNA sequence amplification in human ovarian carcinoma. Cancer Res 55:3380-3385 (1995).

17-Johnson DH: Molecular cloning of DNA from specific chromosomal regions by microdissection and sequence-independent amplification of DNA. Genomics 6:243-251 (19:89).

18-Lidecke HJ, Senger $G$, Claussen $U$, Horsthemke $B$ : Cloning defined regions of human genome by microdissection of banded chromosomes and enzymatic amplification. Nature 338:348-250 (1989).

19. Davis LM, Senger G, Ludecke HJ, Claussen U, Horsthemke B, Zhang SS, Metzroth B, Hohenfellner K, Zable B, Shows TB: Somatic cell hybrid and long-range physical mapping of $11 \mathrm{p} 13$ microdissected genomic clones. Proe Natl Acad Sci USA 87:7005-7009 (1990). 
20-Lengauer $C_{3}$, Eckelt A, Weith A, Endlich N, Ponelies $N$, Lichter $\mathrm{P}$, Gruelich Ka, Cremer $\mathrm{T}$ : Painting of defined chromosomal regions by in situ suppression hybridization of libraries from lasermicrodissected chromosomes. Cytogenet Cell Genet $5627-30$ (1991).

21- Guan XY, Meltzer PS, Trent MM: Rapid generation of whole chromosome painting probes (WCPs) by chromosome microdissection. Genomies 22:101-107 (1992).

22- Guan XY, Meltzer PS, Cao J, Trent JM: Rapid generation of region-specific genomic clones by chromosome microdissection: isolation of DNA from a region frequently deleted in malignant melanoma. Genomics 14:680-684 (1992).

23- Guan XY, Trent JM, Meltzer PS: Generation of band-specific painting probes from a single microdissected chromosome. Fum Mol Genet 8:1117-1121 (1993).

24-Jewett T, Rao N, Grey Weaver R, Stewart W, Thomas IT, Pettinati MJ; Blepharophimosis, Ptosis, and Epicanthus Inversus Syndrome (BPES) associated with interstitial deletion of band $3 \mathrm{q}_{22}$ : Review and gene assignment to the interface of band 3q22.3 and 3q23. Am J Med Genet 47:1147-1150 (1993).

25-Small KW, Stalvey M, Fisher L, Mullen L, Dickel C, Beadles K, Reimer R, Lessner A, Lewis K, Pericak-Vance MA: Blepharophimosis syndrome is linked to chromosome $3 q$. Hum Moll Genet 4:443-448 (1995).

26-ISCN (1985): An international system for human cytogenetic nomenclature, Harnden DG and Klinger HP (Eds); published in collaboration with Cytogen Cell Genet (Karger, Basel 1985). 
CHARACTERIZATION OF A DE NOVO UNBALANCED TRANSLOCATION $\mathrm{t}(14 \mathrm{q} 18 \mathrm{q})$ USING MICRO-FISH.

John J.M. Engelen' ${ }^{1}$, Wil J.G. Loots ${ }^{1}$, Jozefa C.M. Albrechts ${ }^{1}$, Syb B. van der Meer $^{2}$, Astrid S. Plomp ${ }^{1}$, Johannes S.H. Vles ${ }^{3}$, Guus J.H. Hamers' ${ }^{1}$ and Joep P.M. Geraedts ${ }^{1}$.

' Department of Molecular Cell Biology and Genetics, University of Maastricht, Maastricht, The Netherlands.

${ }^{2}$ Department of Pediatrics, University Hospital Maastricht, The Netherlands.

${ }^{3}$ Department of Child Neurology, University Hospital Maastricht, The Netherlands.

Accepted for publication in:

American Journal of Medical Genetics 
We report on a patient with a de novo translocation between the long arm of chromosomes 14 and 18 . The translocation was studied using microdissection in combination with fluorescence in situ hybridization (micro-FISH). Five copies of the chromosomes involved in the translocation were isolated by microdissection and amplified by means of degenerate oligonucleotide primed-polymerase chain reaction (DOP-PCR). Reverse chromosome painting with the biotin-labeled PCR product showed that part of the qarm of chromosome 18 had no signal. The deletion was characterized further by FISH with band-specific probes and it was concluded that the rearrangement was unbalanced: $46, X Y, t(14 ; 18)(14$ pter- $>14 q 22:: 18 q 21.1->18$ qter; 18 pter $->18 q 12.2: 14 q 22$ $\rightarrow 14$ qter). The patient, who presented with psychomotor retardation, mild obesity, pes equinovarus, strabismus and facial anomalies, is compared with previously reported patients with an interstitial deletion of band $18 q 12$. 


\section{Introduction}

Microdissection in combination with fluorescence in situ hybridization (micro-FISH) involves the physical dissection of GTG-banded chromosomes followed by degenerate oligonucleotide primed-polymerase chain reaction (DOP-PCR) and subsequent FISH with the probe obtained. This method, developed by Meltzer et al. ' has been successfully applied in clinical cytogenetics to characterize unidentifiable chromosome abnormalities (Ohta et al. ${ }^{2}$ ), chromosome rearrangements (Zhang et al., ${ }^{3}$; Engelen et al. ${ }^{4}$ ), and marker chromosomes (Thangavelu et al. ${ }^{5}$; Viersbach et al. ${ }^{6}$; Sun et al. Muller-Navia et al. ${ }^{8}$; Engelen et al. ${ }^{9}$ ). Loss of chromosomal material was demonstrated with micro-FISH by Rubtsov et al. ${ }^{10}$, Guan et al. ${ }^{11}$ and Engelen et al. ${ }^{12}$.

In this study micro-FISH was used to characterize a de novo translocation between chromosomes 14 and 18, that was found in an obese, 3-year-old boy with psychomotor retardation and other anomalies. From high-resolution banding studies it was clear that the translocation was unbalanced. Although chromosome painting (Lichter et $\mathrm{al}^{1 \mathrm{t}}$; Pinkel et al. ${ }^{14}$ ) allows the rapid identification of translocations, this technique was insufficient to determine precisely which chromosome band was deleted. However, the application of microdissection and reverse chromosome painting (Carter et al. ${ }^{15}$ ) resulted in the successful identification of the deleted region in this unbalanced de novo translocation. FISH with band-specific probes was applied to characterize the deleted region and the breakpoints more precisely.

\section{Material and methods}

\section{Clinical report}

The patient, a 3-year old boy, was the third child of non-consanguineous, healthy parents. During pregnancy fetal movements were reduced. He was born at term by vacuum extraction, with severe postnatal acidosis (arterial pH 6.80). Birth weight was $2690 \mathrm{~g}$, and length $48 \mathrm{~cm}$. He had a club foot at the right side, for which he was successfully treated. Psychomotor development was retarded, with generalized hypotonia and lack of motoric development until the age of 10 months. He sat without support at the age of 13 months and stood at 21 months. When examined at 2 years and 3 months, we saw a friendly child with a length of $95 \mathrm{~cm}$ (90th centile), weight of 15 $\mathrm{kg}$ ( 75 th centile) and a head circumference of $50.5 \mathrm{~cm}$ (50th-75th centile). He had plagiocephaly, a narrow forehead, deep set eyes, epicanthal folds, convergent strabismus, small mouth with a thin upper lip, high narrow palate, large and broad hands and small and puffy feet. He also had wide set nipples. In the left lumbal region a hairy patch of $4 \mathrm{~cm}$ in diameter was seen. There was bilateral cryptorchidism but otherwise his genitalia were normal. There was mild axial hypotonia and he could not walk without support. He spoke only four words. There were no behaviour problems. A magnetic resonance image (MRI) of the brain was normal, MRI of the spinal cord showed a stenosis at level L4-L5. The findings of the most recent examination at 3 years of age are summarized in table 1 and his distinct craniofacial appearance is illustrated in figure 1 . 


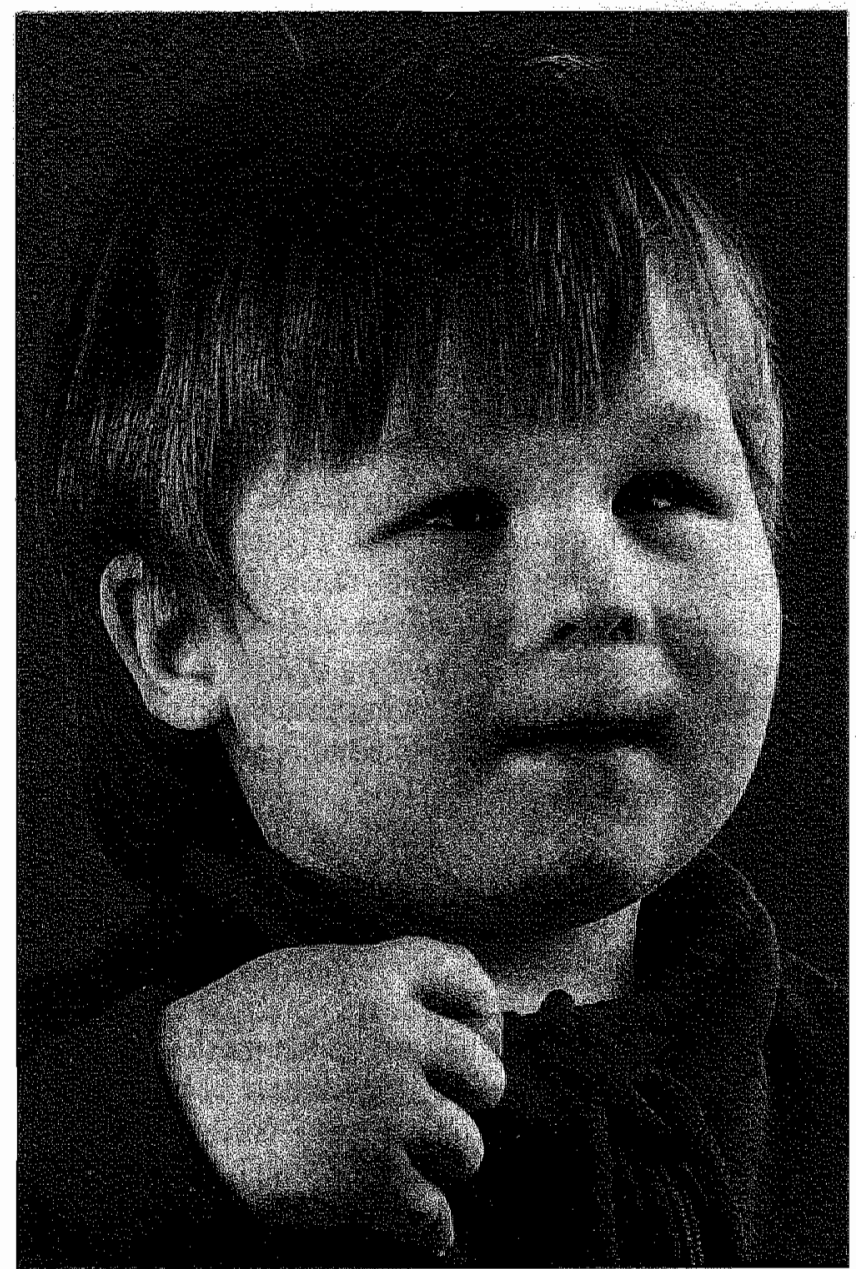

Pict.1: Picture of the patient at the age of three years

\section{Cytogenetics, microdissection and FISH}

Chromosomes were prepared from peripheral blood lymphocytes using the synchronization method of Dutrillaux and Viegas-Pequignot ${ }^{16}$ with minor modifications. Highresolution banding was performed by treatment with trypsin followed by staining with Giemsa to obtain a GTG-banded pattern. 


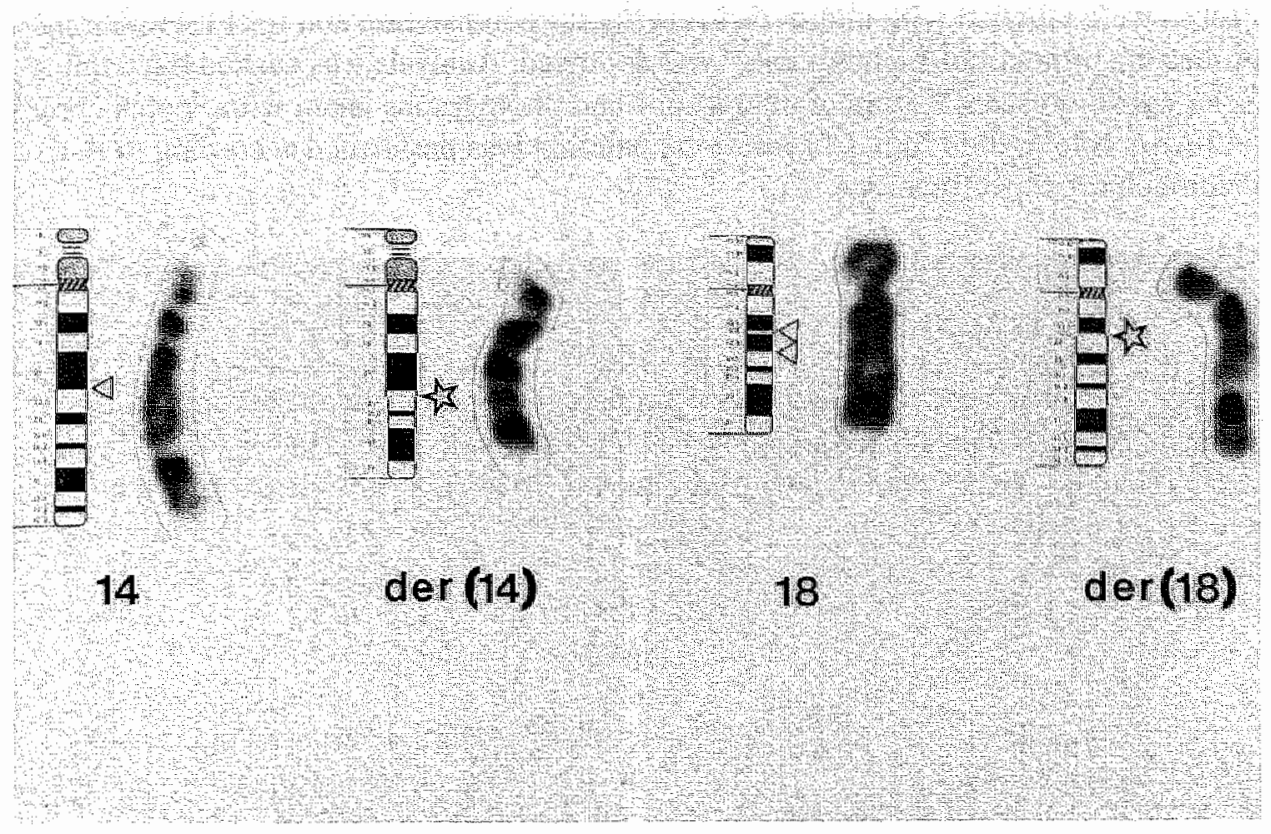

Fig. 1 : Partial karyotype presenting normal GTG-banded chromosomes 14 and 18 and the chromosomes involved in the translocation. Arrows point to the breakpoints, asterisks mark the points of reunion.

For microdissection, routinely fixed cell suspensions stored at $-20^{\circ} \mathrm{C}$ were used to prepare metaphase spreads on coverslips. Dissection of the translocation chromosomes was performed with glass microneedles controlled by a Narishige micromanipulator (MO-202). Five copies of both the derivative chromosome 14 and 18 were collected in a $20 \mu \mathrm{l}$ collection drop; amplification of the dissected DNA by DOP-PCR was performed as described previously (Engelen et al ${ }^{12}$ ). The PCR product was precipitated, dissolved in $50 \mu \mathrm{l}$ T0,1E buffer ( $10 \mathrm{mM}$ TRIS-HCl/0,1 mM Na2EDTA, pH 8.0) and labelled with biotin-14-dATP by nick-translation. FISH with the DOP-PCR product was performed following the protocol of Guan et al. ${ }^{17}$ with minor modifications.

In this study the following band specific probes were used:

References

SCW $0201 \mathrm{C}$

$18 \mathrm{q} 12$

SCW 0307E

$18 \mathrm{q} 12$

D18S46

$18 \mathrm{q} 21.1$

D18S41

Nakashima et al. ${ }^{18}$
Nakashima et al.
Boghosian-Sell et al.
Boghosian-Sell et al. ${ }^{19}$


Probes were labelled with biotin-14-dATP by nick-translation and for FISH with these probes the protocol of Lichter et al ${ }^{20}$ was followed. Analysis was carried out using a Zeiss epi-fluorescent Axiophot microscope and photographs taken with Scotch chrome 640 ASA colour slide film. Chromosome painting was performed according to the manufacturer's specifications.

\section{Results}

Analysis of GTG-banded metaphases demonstrated a translocation between chromosomes 14 and 18. From banding patterns it was concluded that either band $14 \mathrm{q} 23$ or band $18 \mathrm{q} 12.3$ was deleted (fig. 2). Chromosome 14 and 18 specific paints were used to show that the missing chromosome band was not translocated to another chromosome (fig. 3A and 3B). After hybridization of the DOP-PCR probe to normal metaphase chromosomes both chromosomes 14 were found to be completely painted. However, chromosomes 18 lacked fluorescence in region 18q12 (fig. 3C). After hybridization of the DOP-PCR probe to metaphases of the patient, the der(14) and der(18) were completely painted giving evidence that these chromosomes had been completely microdissected and multiplied by DOP-PCR. Also the normal chromosome 14 was completely painted. However, as expected, chromosome 18 showed no signall in band 18 q12 (fig 3D). FISH with probes SCW 0201C (fig. 4A) and SCW 0307E (not shown) to metaphases of the patient confirmed these results, as only the normal chromosome 18 showed a fluorescence signal. After FISH with probes D18S46 (fig. 4B) and D18S41 (not shown) to metaphases of the patient of both probes two fluorescence signals were visible; one signal on chromosome 18 and one signal on the $\operatorname{der}(14)$. This indicates that the distal breakpoint in the q-arm of chromosome 18 is located proximally to D18S46 and D18S41. The FISH results combined with the GTG-banding show that the patient has an unbalanced $46, X Y, t(14 ; 18)(14$ pter- $>14 \mathrm{q} 22:: 18 \mathrm{q} 21.1$ $>18$ qter; 18pter->18q12.2::14q23 $>14$ qter) karyotype. Chromosomes of the parents were normal. 

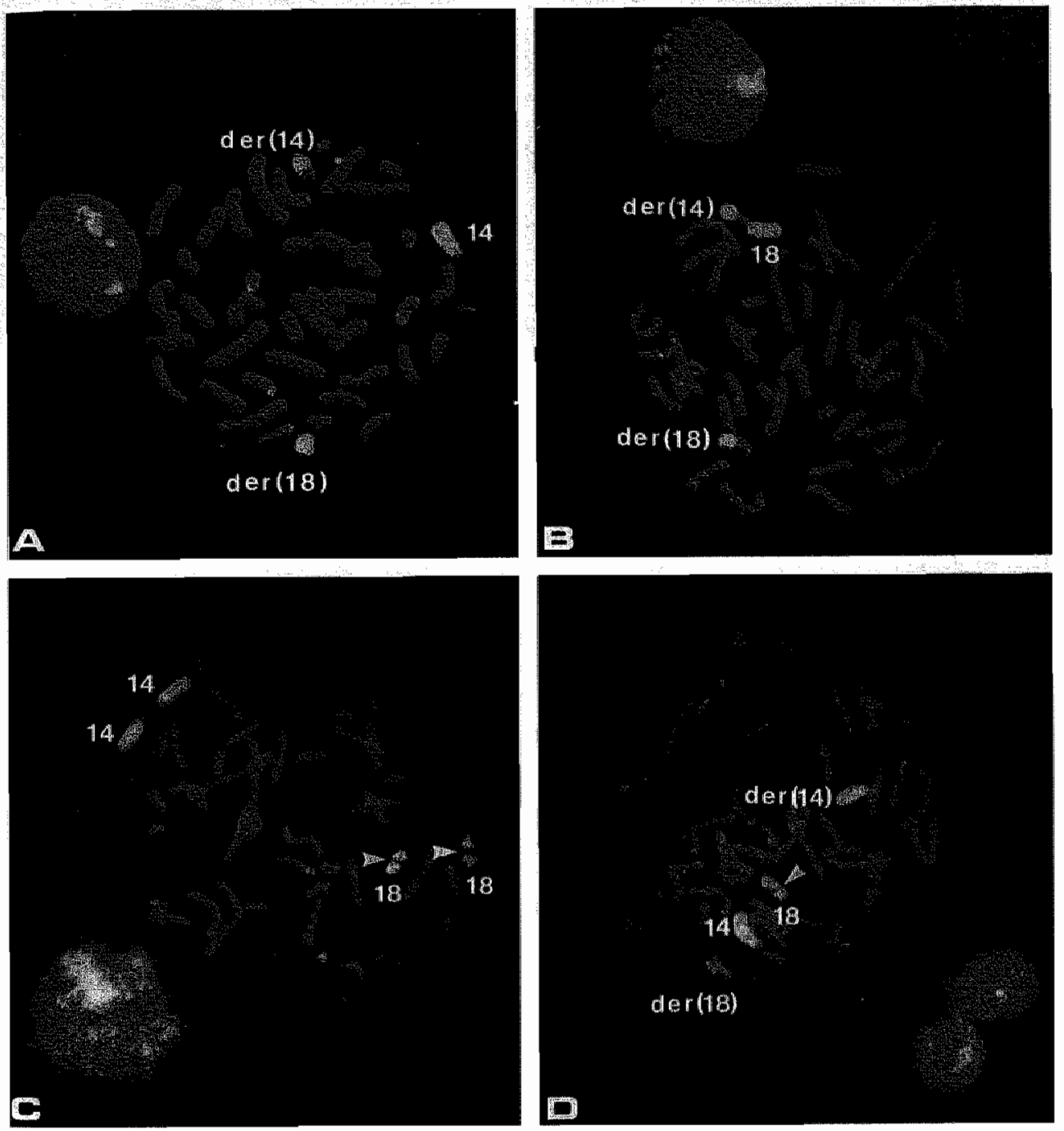

Fig. 3A and 3B: Metaphase chromosomes of the patient after FISH with a chromosome 14 (A) and chromosome 18 (B) specific paint. Fig. 3C: Metaphase of a normal male after FISH with the DOP. PCR probe generated from the chromosomes involved in the translocation. The arrows are pointing to the "deletion" in chromosome 18. Fig. 3D: Metaphase of the patient after FISH with the DOP-PCR probe generated from the chromosomes involved in the translocation. Small arrow marks the "deletion" in chromosome 18. 

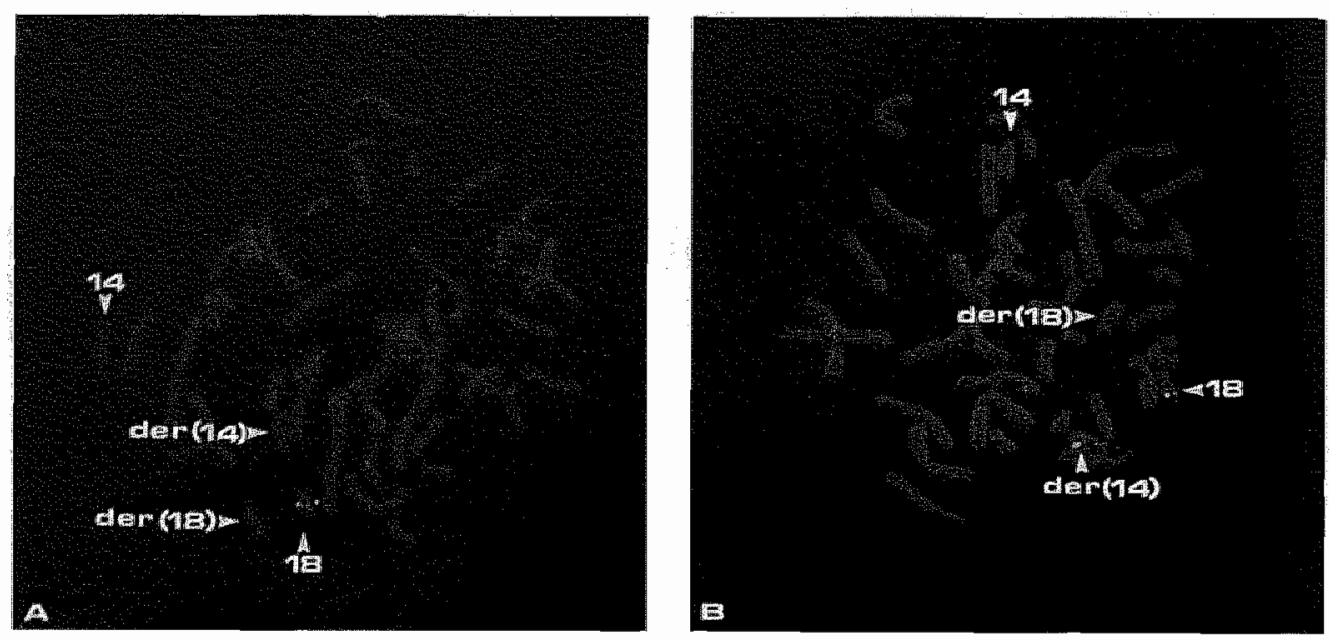

Fig. 4A: Metaphase chromosomes of the patient after FISH with probe SCW 0201C. Fig. 4B: Metaphase chromosomes of the patient after FISH with probe D18S46.

\section{Discussion}

In this study micro-FISH was successfully applied to demonstrate loss of chromosomal material in a patient with a de novo translocation involving chromosomes 14 and 18 . FISH with band-specific probes confirmed the loss of chromosomal material and characterized the breakpoints more precisely. To the best of our knowledge, this case represents the first report of del(18q12.3) due to a de novo translocation.

In Table J, the clinical findings of our case are compared with 13 previously reported cases with deletion of $18 \mathrm{q} 12$. The first 4 patients have a deletion of $18 \mathrm{q} 12$ due to unbalanced transmission of a familial insertion translocation $(11 ; 18)(\mathrm{p} 15 ; \mathrm{q} 11 \mathrm{q} 21)$, the remaining 9 cases have de novo deletions. In all patients with this deletion moderate to severe mental retardation is reported. In addition, ataxia, seizures or EEG abnormalities, hypotonia and a tendency to mild obesity are commonly reported. Craniofacially, the younger patients reported in the literature bear a striking resemblance to our patient. They share their mild facial anomalies that include prominent forehead with short nose, epicanthal folds, deep-set eyes, abnormal mouth with thin upper lip, and ear anomalies. Table 1 shows that the clinical findings of patients with a larger deletion and breakpoints in 18q11 and 18q21 do not differ significantly from the clinical findings of patients with deletion of only chromosome band $18 \mathrm{q} 12.3$. The smallest region of overlap for these 14 cases is chromosome band 8q12.3 (figure 5). As could be expected, this clinical picture does not resemble the terminal deletion 18(q21->qter) phenotype which results in the de Grouchy syndrome (de Grouchy and Turleau ${ }^{21}$ ). 
TABLE 1. Clinical findings in 14 cases with deletions involving chromosome band $18 \mathrm{q} 12.3$.

$\begin{array}{lllllllllllllll}\text { References: } & 1 & 1 & 1 & 1 & 2 & 3 & 4 & 5 & 5 & 6 & 7 & 7 & 7 & \text { our } \\ & \mathrm{a} & \mathrm{b} & \mathrm{c} & \mathrm{d} & & & & \mathrm{a} & \mathrm{b} & & \mathrm{a} & \mathrm{b} & \mathrm{c} & \mathrm{pt}\end{array}$

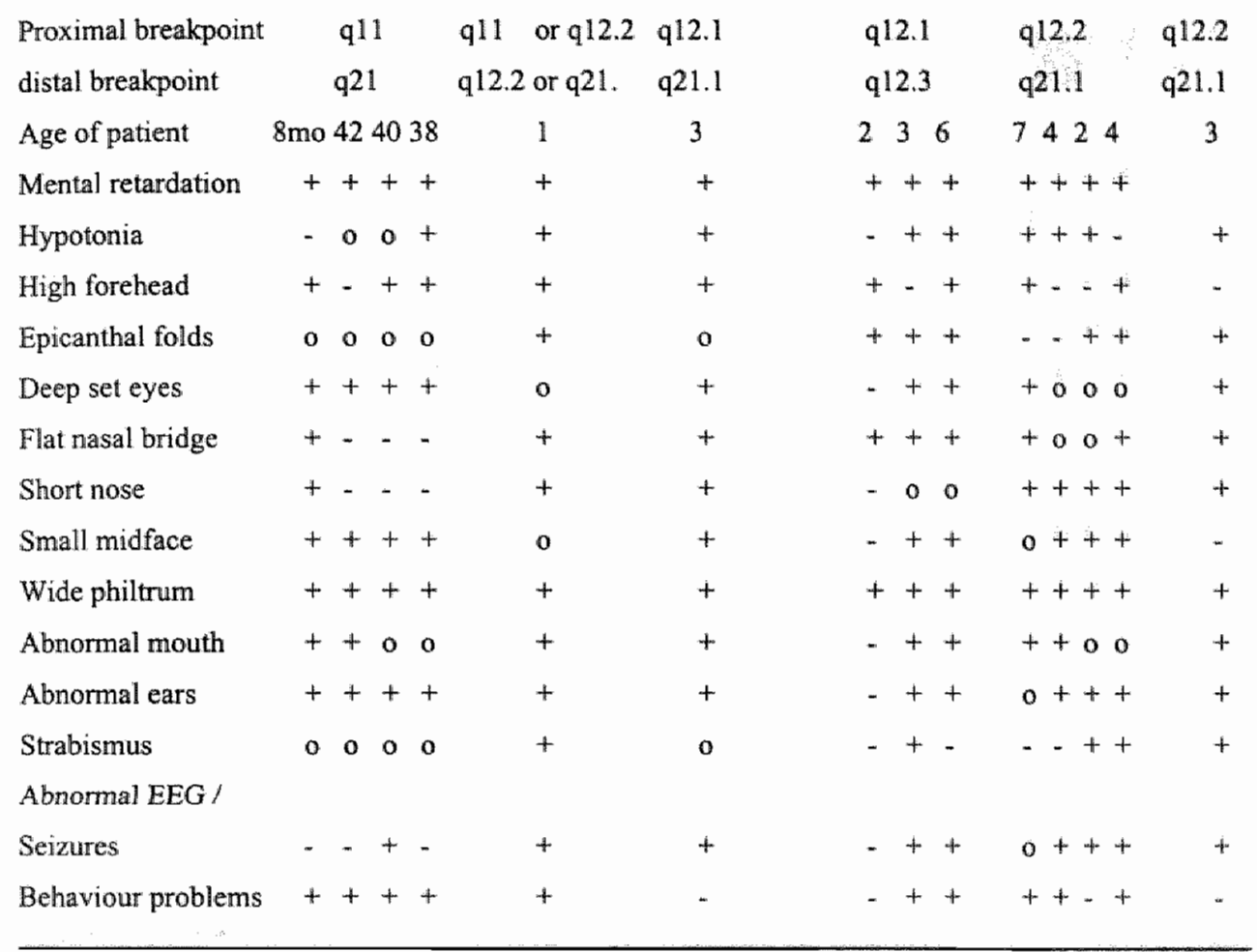

+: present, -: not present, o: not documented.

\section{References:}

1: Chudley et al. ${ }^{25}$, patients IIJ/10 (a), II/4 (b), II/S (c), II/6 (d).

2: Wilson et al. ${ }^{26}$

3: Krasikov et al. 27 .

4: Suhr et al. ${ }^{28}$.

5: Poissonnier et al. ${ }^{29}$ patients $I$ (a) and 2 (b).

6: Wilson and Al Saadi ${ }^{30}$.

7. Schinzel et all. ${ }^{31}$ patients 1 (a), 2 (b) and 3 (c). 
The most likely mechanism for the production of the reported abnormality involves 3 chromosomal breaks: 2 in chromosome 18 , producing a fragment consisting of $18 \mathrm{q} 12.3$, and a simultaneous break in $14 \mathrm{q} 22$. Although the clinical picture of our patient is most likely caused by deletion of chromosome band $18 \mathrm{q} 12.3$, involvement of a small submicroscopic deletion or a disrupted gene (sequence) at the breakpoint in chromosome 14 cannot be completely ruled out. This is supported by data of Kousseff et al ${ }^{22}$, Fryns et $\mathrm{al}^{23}$ and Warburton ${ }^{24}$ who report that mental retardation is more frequently present in patients with a de novo translocation than in carriers of familial translocations.

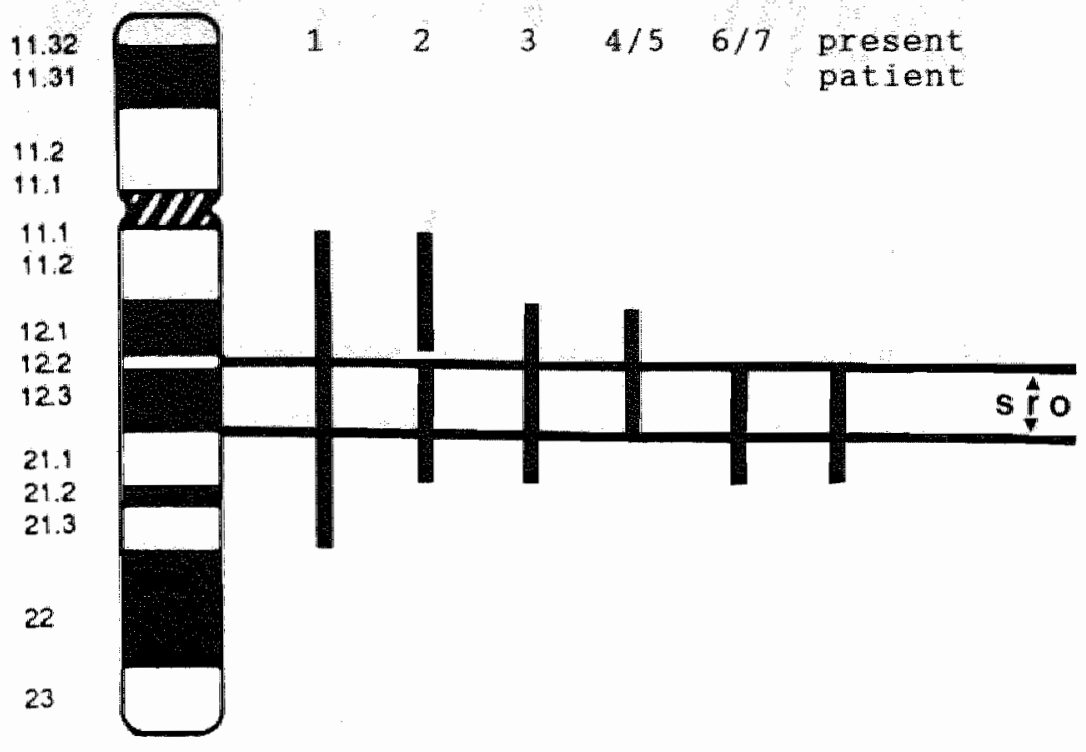

Fig. 5 : Ideogram of chromosome 18 and schematic representation of the deleted region in the patients from table I. SRO: smallest region of overlap.

In summary, it seems that patients with interstitial deletion $18 \mathrm{q} 12$ lack major malformations and have a normal lifespan. Consistent clinical findings in young patients are mental retardation, hypotonia, epicanthal folds, short nose with flat bridge, wide philtrum, abnormal mouth and ears, deep-set eyes, mild obesity and abnormal EEG. Furthermore, this study illustrates the value of micro-FISH for relatively rapid and precise characterization of an aberrant chromosome. That this is possible in three days makes it a perfectly suitable method for the clarification of chromosome abnormalities in areas such as prenatal diagnosis.

\section{Acknowledgements}

The authors thank Dr. J. Overhauser and Dr. T. Imamura for providing the probes used in this study. 


\section{References}

I-Meltzer PS, Guan XY, Burgess A, Trent J: Rapid generation of region specific probes by chronosome microdissection and their application. Nature Genet 1:24-28 (1992).

2-Ohta $T$, Tohma $T$, Soejina $H$, Fukushima $Y$, Naga $T$, Yoshura $K$, Jinno $Y$, Niikawa $N$ : The origin of cytogenetically unidentifiable chromosome abnormalities: six cases ascertained by targeted chromosome-band painting. Hum Genet 92:1-5 (1993).

3- Zhang J, Meltzer P, Jenkins R, Guan XY, Trent J: Application of chromosome microdissection probes for elucidation of BCR-ABL fusion and variant Philadelphia chromosome translocations in chronic myelogenous leukemia. Blood 12:3365-3371 (1993).

4- Engelen JJM, Loots WJG, Albrechts JCM, Motoh PCC, Fryns JP, Hamers AJH, Geraedts JPM: Disclosure of five breakpoints in a complex chromosome rearrangement (CCR) by microdissection and FISH. J Med Genet 33:562-566 (1996).

5-Thangavelu M, Pergament E, Espinosa R, Bohlander SK: Characterization of marker chromosomes by microdissection and fluorescence in situ hybridization. Prenat Diagn 14: 583-588 (1994). 6-Viersbach $\mathrm{R}$, Schwanitz $\mathrm{G}$, Nothen M: Delineation of marker chromosomes by reverse chromosome painting using only a small number of DOP-PCR amplified microdissected chromosones. Hum Genet 93:663-667 (1994).

7-Sun Y, Rubinstein J, Soukop S, Palmer CG: Marker chromosome 21 identified by microdissection and FISH. Am J Med Genet 56:151-54 (1995).

8-Muller-Navia J, Nebel A, Schleiermacher E: Complete and precise characterization of marker chromosomes by application of microdissection in prenatal diagnosis. Hum Genet 96:661-667 (1995). 9- Engelen JJM, Loots WIG, Motoh PCC, Moog U, Hamers AJH, Geraedts JPM: Marker chromosome identification by micro-FISH. Clin Genet 49:242-248 (1996).

10- Rubtsov N, Senger G, Kuzcera H, Neumann A, Kelbova C, Junker K, Beensen V, Claussen U: Interstitial deletion of chromosome 6q: precise definition of the breakpoints by microdissection, DNA. amplification, and reverse painting. Hum Gener 97:705-709 (1996).

11-Guan XY, Meltzer PS, Cao J, Trent JM: Rapid generation of region-specific genomic clones by chromosome microdissection: isolation of DNA from a region frequently deleted in malignant melanoma. Genomics 14:680-684 (1992).

12- Engelen JJM, Albrechts JCM, Loots WJG, Hollanders-Crombach HTM, Hamers AJH, Geraedts JPM: Application of micro-FISH to delineate deletions. Cytogenet Cell 75:167-171 (1997).

13-Lichter P, Cremer T, Borden J, Manuelidis L, Ward DC: Delineation of individual human chromosomes in metaphase and interphase cells by in situ suppression hybridization using recombinant DNA libraries. Hum Genet 88:224-234 (1988).

14-Pinkel D, Landegent J, Collins C, Fuscoe J, Segraves R. Lucas J, Gray J: Fluorescence in situ hybridization with chromosome-specific libraries: detection of trisomie 21 and translocation of chromosome 4. Proc Natl Acad Sci USA 85:9138-9142 (1988).

15- Carter NP, Ferguson-Smith MA, Perryman MT, Telenius H, Pelmear AH, Leversha MA, Glancy MT, Wood SL, Cook K, Dyson HM, Ferguson-Smith ME, Willatt LR: Reverse chromosome painting: a method for the rapid analysis of aberrant chromosomes in clinical cytogenetics. $J$ Med Genet 29:299-307 (1992).

16-Dutrillaux B, Viegas-Pequignot E: High resolution R- and G-banding in the same preparation. Hum Genet 57:93-95 (1981).

17-Guan XY, Cargille CB, Anzick SL, Thompson FH, Meltzer PS, Bittner ML, Taetle R, McGill JR, Trent JM: Chromosome microdissection identifies cryptic sites of DNA sequence amplification in human ovarian carcinoma. Cancer Res 55:3380-3385 (1995).

18-Nakashima H, Sakai M, Inaba R, Imamura T: Isolation and fluorescence in situ hybridization mapping of 60 cosmid clones on human chromosome 18. Genomics 19:577-580 (1994).

19- Boghosian-Sell L, Mewar R, Harrison W, Shapiro RM, Zackai EH, Carey J, Davis-Keppen L, Hudgins L, Overhauser J: Molecular mapping of the Edwards syndrome phenotype to two noncontiguous regions on chromosome 18. Am J Hum Genet 55:476-483 (1994).

20-Lichter $P$, Tang CC, Call $K_{y}$ Hermanson $G$, Evans HJ, Housman D, Ward DC: High resolution 
mapping of human chromosome 11 by in situ hybridization with cosmid clones. Science 247:64-69 (1990).

21. Grouchy J de. Turleau C: Clinical atlas of Human Chromosomes. New York: John Wiley, (1984).

22-Kousseff BG, Nichols P, Essig YP, Miller $\mathrm{K}$, Weiss A, Tedesco TA: Complex chromosome rearrangements and congenital anomalies. Am J Med Genet 26:771-782 (1987).

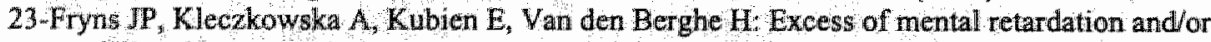
congenital mal formation in reciprocal translocations in man. Hum Genet 72:1-8 (1986).

24- Warburton D: De novo balanced chromosome rearrangements and extra marker chromosomes identified at prenatal diagnosis. Am J Hum Genet 49-995-1013 (1991).

25- Chudley AE, Bauder F, Ray M, McAlpine PJ, Pena SDJ, Hamerton IL (1974): Familial mental retardation in a family with an inherited chromosome rearrangement. J Med Genet 11:353-363 $(1974)$.

26-Wilson MG, Towner JW, Forsman I, Siris E: Syndromes associated with deletion of the long arm of chromosome 18 (del(18q)). Am J Med Genet 3:155-174 (1979).

27-Krasikov N, Thompson K, Singh Sekhon G: Brief clinical report: Monosomy 18q12.1 >21.1: A recognizable aneuploidy syndrome? Am J Med Genet 43:531-534 (1992).

28-Suhr LC, Ledbetter DH, Greenberg F: Brief clinical report: interstitial deletion of chromosome 18 [del(18)(q11.2q12.2 or q12.2q21.1)]. Am J Med Genet 41:15 17 (1991).

29-Poissonnier M, Turleau C, Olivier-Martin M, Milleret-Proyart MJ, Prieur M, Dubos M, Cabanis MO, Mugneret F, Blanc Ph, Noel L: Interstitial deletion of the proximal region of the long arm of chromosome 18, del(18q12) a distinct clinical entity ? Ann Genet 35:146-151 (1992).

30. Wilson GN, Al Saadi AA: Obesity and abnormal behaviour associated with interstitial deletion of chromosome 18 (q12.2q21.1). J Med Genet 26:62-63 (1989).

31-Schinzel A, Binkert F, Lillington DM, Sands M, Stocks RJ, Lindenbaum RH, Matthews H, Sheridan H. Interstitial deletion of the long arm of chromosome 18, del(18)(q12.2q21.11): a report of three cases of an autosomal deletion with a mild phenotype. J Med Genet 28:352-355 (1991). 
DUPLICATION OF CHROMOSOME REGION 15Q11-15Q13 IN A PATIENT WITH SIMILARITIES TO PRADER-WILLI SYNDROME CONFIRMED BY REGION-SPECIFIC AND BAND-SPECIFIC FISH.

John J.M. Engelen, Wil J.G. Loots, Jozefa C.M. Albrechts, Constance T.R.M. Schrander-Stumpel, Ruth Dirckx, Guus J.H. Hamers and Joep P.M. Geraedts.

Department of Molecular Cell Biology and Genetics, University of Maastricht, Maastricht, The Netherlands.

Submitted for publication 
We report on a patient presenting with mental retardation and obesity and a proximal duplication of chromosome 15. The patient shared some clinical signs with PraderWilli syndrome. With a region specific paint, generated by microdissection, a duplication in region 15q11.2-q13 was shown to be present. Subsequently, FISH with probes localized to chromosome region 15q11.2-q12 further characterized this chromosome aberration and a duplication of sequences which are frequently deleted in Prader-Willi and Angelman syndrome was demonstrated. 


\section{Introduction}

Prader-Willi syndrome (PWS) and Angelman syndrome (AS) are mental retardation disorders which are caused by the loss of function of genes proximal on chromosome 15 (q1 l-q13). The paternal origin of deletions in PWS, as well as the occurrence of maternal uniparental disomie (UPD), suggest that a gene(s) associated with PWS is active on the paternal chromosome only. In AS, maternal deletions and paternal UPD suggest that the AS gene(s) is active on the maternal chromosome only. This different parental origins of deletions and UPD strongly implicate genomic imprinting for this chromosome region ( Nicholls $^{1}$ ).

Less frequently, proximal duplication in the long arm of chromosome 15 has been described in patients with Prader-Willi or "Prader-Willi-like" syndrome (FuhrmannRieger ${ }^{2}$, de France et al. ${ }^{3}$, Berry et al ${ }^{4}$, Pettigrew et al. ${ }^{5}$, Rauch and Nevin ${ }^{6}$, Li et all. ${ }^{7}$ ) in a patient with similarities to Angelman syndrome (Clayton-Smith et al. ${ }^{8}$ ) and in mentally retarded patients without the typical clinical features of these syndromes (Pettigrew et al. ${ }^{5}$, Brookwell and Veleba" ${ }^{9}$, Turolla et al. ${ }^{10}$, Shohat et al. ${ }^{11}$, Ludowese et al. ${ }^{12}$, Hirsch et al. ${ }^{13}$, Crawford et al. $\left.{ }^{14}\right)$. Beside that, a proximal duplication is known which in phenotypically normal individuals is segregating as a polymorphism (Li et al. ${ }^{7}$, Brookwell and Veleba ${ }^{9}$, Turolla et al ${ }^{10}$, Ludowese et al. ${ }^{12}$, Hirsch et al. ${ }^{13}$, Jalal et al. ${ }^{15}$, Jalal et al ${ }^{16}$ ). although transmission from a phenotypically normal parent to an abnormal child has also been reported (Berry et al. ${ }^{4}$, Rauch and Nevin ${ }^{6}, \mathrm{Li}$ et al. ${ }^{7}$, Brookwell and Veleba ${ }^{9}$, Turolla et al. ${ }^{10}$, Shohat et al. ${ }^{11}$,Ludowese et al. ${ }^{12}$ ). This report is on the delineation of a proximal $15 \mathrm{q}$ duplication in a 12-year-old mentally retarded boy with some of the typical clinical features of PWS. Cytogenetic analysis of G-banded chromosomes disclosed a de novo duplication in the proximal region of chromosome 15 . With a region $15 \mathrm{q} 11$-q13 specific paint, that was made by microdissection and subsequent degenerate oligonucleotide primed-PCR (DOP-PCR), metaphases of the patient were painted. Furthermore, FISH with locus-specific probes was applied to characterize the duplication more precisely.

\section{Material and methods}

\section{Clinical report}

The patient is the second child of healthy parents. His elder sister is normal. Pregnancy and birth were unremarkable. No early hypotonia, nor feeding problems existed. Development was generally delayed and special schools were necessary. Weight was at the high percentiles from the first year of life. At the age of 12 years, the proband was referred because of mild mental retardation and obesity, suggesting PWS. Clinical examination showed an obese boy with some aspects of the PWS phenotype (fig. 1). Height was between 10 and 25 th percentile, weight for height was well above the 97 th percentile. Head circumference was normal. Minor dysmorphism of the face included high forehead with small biparietal diameter, slightly upslanting palpebral fissures and myopia. A tendency for overconsumption was present. Saliva was thick and the teeth were very bad looking because of caries. Hands were small $(<\mathrm{P} 3)$ and soft. Genital 
development was early pubertal, penis length being $5 \mathrm{~cm}$. Skin picking was apparent and according to the parents tantrums were common. Apart from the early data, clinical and behavioural phenotype of the proband were judged to be compatible with the diagnosis of PWS.

\section{Major criteria (1 point each)}

Infantile central hypotonia

Infantile feeding problems/fallure to thrive

Rapid weight gain between $\mathbb{l}$ and 6 years

Characteristic factal features

Hypogonadism: genital hypoplasia, pubertal deficiency

Developmental delay/mental retardation

Minor criteria ( $1 / 2$ point each)

Decreased fetal mowement and infantile lethargy

Typical behavioural problems

Sleep disturbance/sleep apnoea

Short stature for the family by age 15 years

Hypopigmentation

Small hands and feet for height age

Narrow hands with straight ulnar border

Esotropia, myopia

Thick, viscous salliva

Speech articulation defects

Skin picking

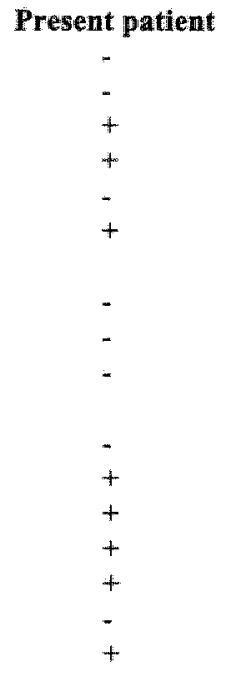

Table 2: Summary of the clinical diagnostic criteria for Prader-Willi syndrome (adapted from Holm et al. ${ }^{17}$ ), and the clinical signs present in our patient. The diagnosis should be strongly suspected in children under 3 years of age with five points, three from major criteria, or in those above 3 years with eight points, four from major criteria.

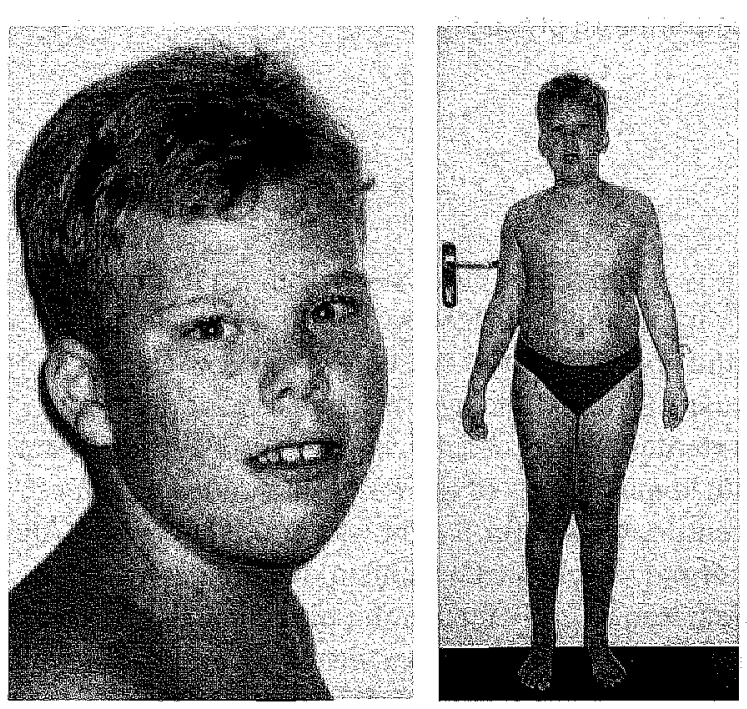

Fig. 1:

The proband, a 12-year-old boy. 


\section{Cytogenetics}

Blood lymphocyte cultures for chromosome studies were synchronized overnight with thymidine, treated with 5-BrdU for 6 hours and ethidiumbromide for 1.5 hours during the last $\mathrm{S}$-fase before harvest (Dutrillaux et al. ${ }^{18}$ ). High resolution banding was performed by treatment with trypsin followed by staining with Giemsa to obtain a GTG-banded pattern.

\section{Microdissection and fluorescence in situ hybridization}

A region 15q11-q13 specific paint was produced by microdissection of an isochromosome 15 (15pter->q13::q13->15pter). Five copies of this marker chromosome were dissected and amplified by DOP-PCR as described previously (Engelen et al. ${ }^{19}$ ). In brief, the dissected chromosomal material was transferred to a $20 \mu \mathrm{l}$ collection drop (containing $250 \mu \mathrm{g} / \mathrm{ml}$ proteinase- $\mathrm{K}$ ) in a $0.5 \mathrm{ml}$ thin walled microcentrifuge tube. Next, the collection drop was incubated at $37^{\circ} \mathrm{C}$ for $30 \mathrm{~min}$ (proteinase- $\mathrm{K}$ treatment) and at $90^{\circ} \mathrm{C}$ for $10 \mathrm{~min}$ (proteinase- $\mathrm{K}$ inactivation). The universal primer $5^{\prime}$ CCGACTCGAGNNNNNNATGTGG 3' was used in the DOP-PCR as suggested by Telenius et al. ${ }^{20}$ The PCR buffer contained $100 \mu \mathrm{M}$ of each dNTP, $2.5 \mathrm{mM} \mathrm{MgCl} 2$, $50 \mathrm{mM} \mathrm{KCl}, 10 \mathrm{mM}$ Tris- $\mathrm{HCl} \mathrm{pH} 8.3,0.1 \mathrm{mg} / \mathrm{ml}$ gelatine, $0.1 \% \mathrm{NP}-40,0.1 \%$ Tween$20,1.5 \mu \mathrm{M}$ universal primer and 0.5 U super Taq DNA polymerase (HT Biotechnology) in a final volume of $50 \mu \mathrm{l}$. For initial denaturation the mixture was heated to 93 ${ }^{\circ} \mathrm{C}$ for $3 \mathrm{~min}$, followed by 8 cycles of $1 \mathrm{~min}$ at $94{ }^{\circ} \mathrm{C}, 1 \mathrm{~min}$ at $30^{\circ} \mathrm{C}, 1 \mathrm{~min}$ at $45^{\circ} \mathrm{C}$ and $3 \mathrm{~min}$ at $72{ }^{\circ} \mathrm{C}$ and by 28 cycles of $1 \mathrm{~min}$ at $94^{\circ} \mathrm{C}, 1 \mathrm{~min}$ at $56{ }^{\circ} \mathrm{C}, 3 \mathrm{~min}$ at $72^{\circ} \mathrm{C}$ with a final extension step at $72{ }^{\circ} \mathrm{C}$ for $10 \mathrm{~min}$. The DOP-PCR experiments contained a negative control and experiments were proceeded only if DNA synthesis was not apparent in this control. PCR product was precipitated and purified with $4 \mathrm{M}$ ammonium acetate and isopropanol, washed with ethanol (98\%), dissolved in $50 \mu \mathrm{l} \mathrm{T0,1 \textrm {E }}$ buffer ( $10 \mathrm{mM}$ TRIS-HCl/0,1 mM Na2EDTA, $\mathrm{pH} 8.0$ ) and biotin labeled by nick translation. FISH with this region specific paint was performed following the protocol of Guan et $\mathrm{al}_{.}{ }^{21}$ with only minor modifications. Additionally, the following locus specific probes were used:

\begin{tabular}{lllll} 
Locus & Probename & Size $(\mathrm{kb})$ & Chromosome-region & Reference \\
\cline { 3 - 5 } D15S11 & A156E1 & 250 & $15 \mathrm{q} 11.2$-q12 & Kuwano et al ${ }^{22}$ \\
GABRB3 & B25E9 & 150 & $15 \mathrm{q} 11.2$-q12 & Kuwano et al.
\end{tabular}

The probes were biotin-14-dUTP labeled by nick translation and for FISH the protocol of Lichter et al ${ }^{23}$ was followed. The slides were examined with a Zeiss Axiophot fluorescence microscope and photographed using Scotchchrome 640 ASA colour slide film. 


\section{Methyllation analysis}

Genomic DNA was digested with Hind III and Hpa II. Fragments were separated by agarose gel electrophoresis and analysed by Southern blot hybridization with probe PW71B for D15S63 (Dittrich et al. ${ }^{24}$ ).

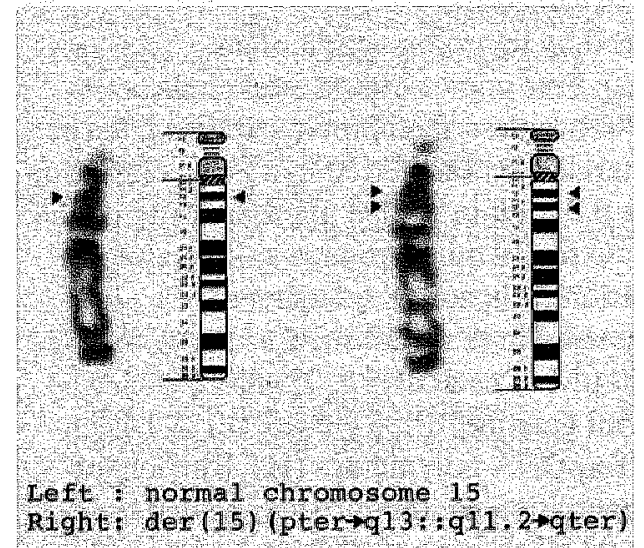

A

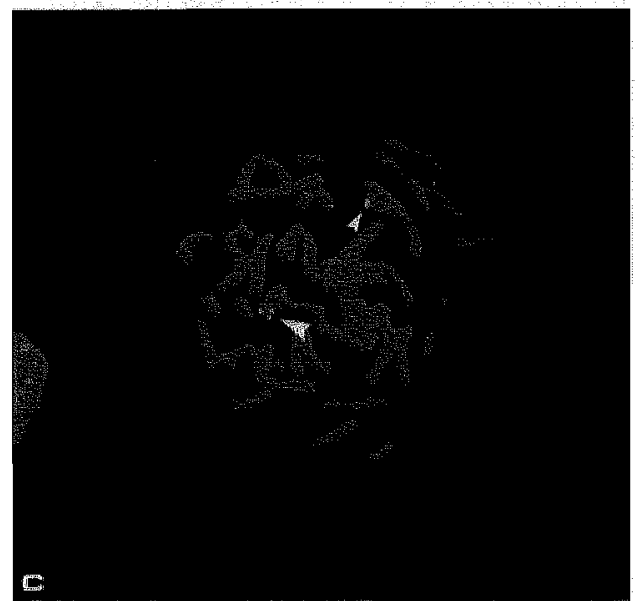

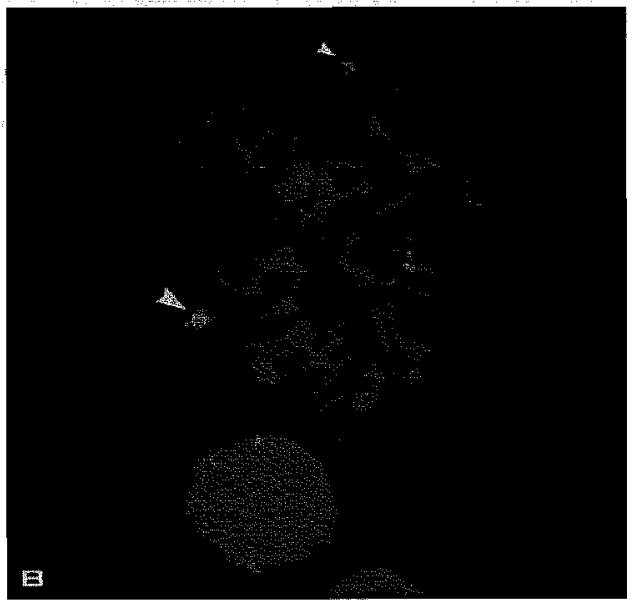

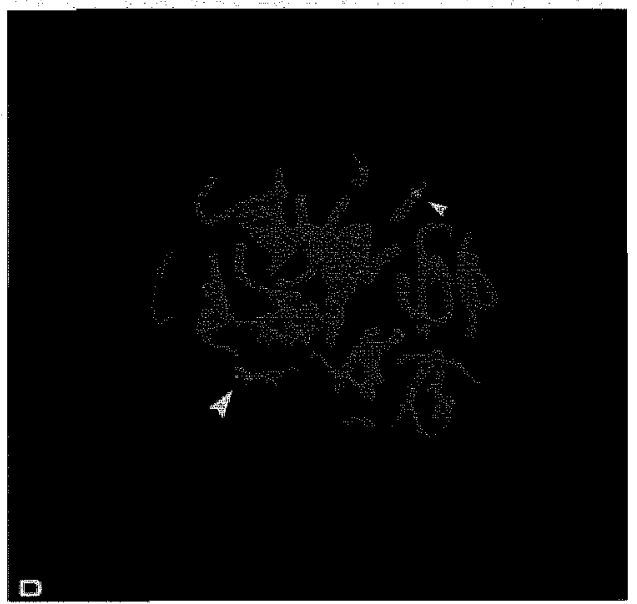

Fig.2A: Partial karyotype showing G-banded chromosome 15 (left), chromosome 15 with duplication q11.2-q13.1 (right) and their idiograms. Fig.2B: FISH with the region $15 q 11-15 q 13$ specific paint to a metaphase of the patient. Small and large arrows point to normal chromosome 15 and chromosome 15 with proximal duplication. Fig.2C and 2D: FISH with probe A156E1 and B25E9 to a metaphase of the patient. Small and large arrows point to normal chromosome 15 and chromosome 15 with proximal duplication. 


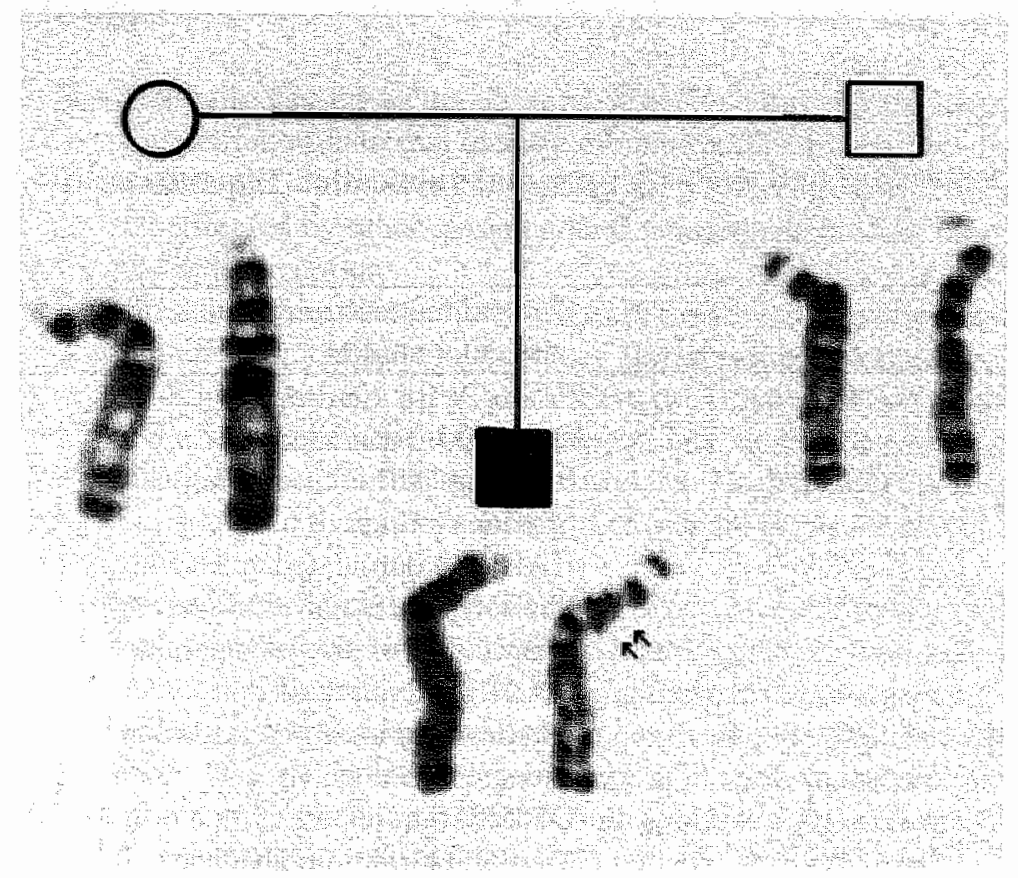

Fig. 3: Partial karyotype showing G-banded chromosomes 15 of the mother (left), patient (middle) and father (right). Arrows point to chromosome 15 with the duplication.

\section{Results}

Cytogenetic analysis of $\mathrm{G}$-banded chromosomes revealed a proximal duplication in one chromosome 15 in all metaphases (fig. 2A). FISH with the region-specific paint to metaphases of the patient showed that the fluorescence signal in the aberrant chromosome 15 was about two times the size of the signal in the normal chromosome 15 (fig. 2B). FISH with locus specific probes A156E1 and B25E9 showed, for both probes, two pairs of fluorescent spots on the aberrant chromosome 15 and one pair of spots on the normal chromosome 15 (fig. $2 \mathrm{C}$ and $2 \mathrm{D}$ respectively). The parents of the patient had normal karyotypes. Comparison of the polymorphic regions of chromosomes 15 of the parents and the patient revealed that the aberrant chromosome was inherited from the father (fig. 3). Methylation status analysis showed that a maternal $6.6 \mathrm{~kb}$ band as well as a paternal $4.7 \mathrm{~kb}$ band were present, demonstrating normal contribution of parental chromosomes 15 . 
Table 1: Clinical features of patients with proximal duplication $15 q$ and results of molecular stu dies.

\begin{tabular}{|c|c|c|}
\hline Author & Age & $\begin{array}{l}\text { Clinical features and results of } \\
\text { molecular studies. }\end{array}$ \\
\hline$\overline{\text { Li et al. }}{ }^{6}$ & 0 & $\begin{array}{l}\text { Prader-Willi syndrome. } \\
\text { GABRB3 duplicated. }\end{array}$ \\
\hline Li et al. ${ }^{6}$ & $?$ & $\begin{array}{l}\text { Phenotypically normal mother of } \\
\text { previous patient. } \\
\text { GABRB3 duplicated. }\end{array}$ \\
\hline Li et al. ${ }^{6}$ & $?$ & $\begin{array}{l}\text { Phenotypically normal father and } \\
\text { grandfather of previous patients. } \\
\text { GABRB3 duplicated. }\end{array}$ \\
\hline Clayton-Smith et al. $^{7}$ & $6 y$ & $\begin{array}{l}\text { Ataxia, mild mental retardation } \\
\text { and speech delay. } \\
\text { D15S10 duplicated. }\end{array}$ \\
\hline Hirsch et al. ${ }^{12}$ & $4 y$ & $\begin{array}{l}\text { Mental retardation, absence } \\
\text { of speech and autistic disorder. } \\
\text { D15S11-SNRPN-GABRB3 duplicated. }\end{array}$ \\
\hline Hirsch et al. ${ }^{12}$ & $?$ & $\begin{array}{l}\text { Intellectually normal mother of } \\
\text { previous patient. } \\
\text { D15S11-SNRPN-GABRB3 duplicated. }\end{array}$ \\
\hline Crawford et all. ${ }^{13}$ & $8 y$ & $\begin{array}{l}\text { Moderate mental retardation and } \\
\text { autistic behaviour. } \\
\text { D15S10-D15S11-SNRPN-GABRB3 } \\
\text { duplicated }\end{array}$ \\
\hline Jalal et al..$^{14}$ & 0 & $\begin{array}{l}\text { Phenotypically normal neonate } \\
\text { ascertained by amniocentesis. } \\
\text { D15S11-GABRB3 single copies. }\end{array}$ \\
\hline Jalal et al..$^{14}$ & $?$ & $\begin{array}{l}\text { Phenotypically normal father of } \\
\text { prewious patient } \\
\text { D15S11-GABRB3 single copies. }\end{array}$ \\
\hline Present patient & $12 \mathrm{y}$ & $\begin{array}{l}\text { Obesity, mental retardation, small soft } \\
\text { hands, myopia, caries, tantrums, skin } \\
\text { picking. } \\
\text { D15S11-GABRB3 duplicated. }\end{array}$ \\
\hline
\end{tabular}




\section{Discussion}

PWS is generally caused by the absence of the paternal chromosome $15 \mathrm{q} 12$ region due to (micro)deletion, uniparental disomy or abnormal DNA methylation due to a mutation in the imprinting centre (Buiting et al. ${ }^{25}$ ). Occasionally the critical region involved is affected by other chromosomal rearrangements like translocations, inversions or duplications.

In our patient with similarities to $\mathrm{PWS}$, high resolution banding showed a proximal duplication of chromosome 15. As whole chromosome painting would not differentiate between a duplication of $15 q 11.2-q 13$ and a proximal insertion of another region of chromosome 15 , we decided to paint the patients" metaphases with a region-specific paint. With this paint, the aberrant chromosome 15 showed a visually increased fluorescent signal in the proximal region, proving that region $15 q 11-q 13$ was involved in the duplication.

Kuwano et al..$^{22}$ used probes A156E1 and B25E9, specific for two loci in region 15q11.2-q12, to study 8 patients with PWS and 3 patients with AS. In all eleven patients a deletion for the region containing these probes was demonstrated. FISH with these probes to metaphases of our patient confirmed the duplication, as the aberrant chromosome 15 showed two pairs of fluorescent spots in the proximal region. Methylation analysis of locus D15S63 with probe PW71 however detected a normal biparental methylation pattern. In patients with proximal duplication in chromosome 15 reported in the literature, only the past four years molecular genetic studies or FISH with locus specific probes have been performed. Clinical features of these patients and the results of the molecular studies are listed in table 1. ClaytonSmith ef al. ${ }^{8}$ were the first to demonstrate a duplication of D15S10 in a patient with similarities to AS. Later, FISH with specific probes for D15S11, D15S10, SNRPN and/or GABRB3 (fig. 4) was used to prove a duplication of (part of) 15q11-q13 in aberrant chromosomes 15 of a child with PWS (Li et al. ${ }^{7}$ ), a child with autism (Hirsch et al. ${ }^{13}$ ) and a child with moderate mental retardation and autistic behaviour (Craw ford et al. ${ }^{(4)}$ ).

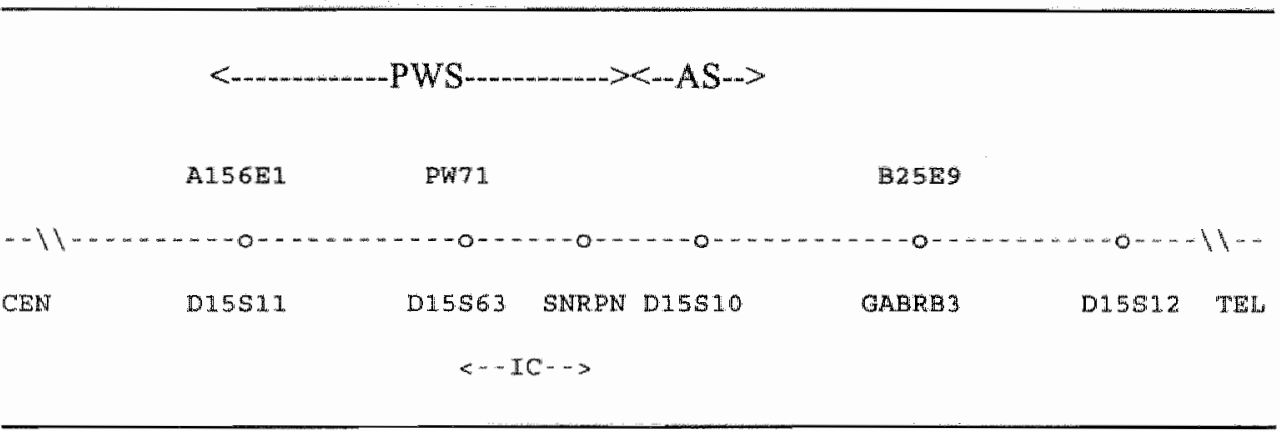

Fig. 4: Genetic map of chromosome region 15q11-q13, (modified from ref, 32) illustrating the position of genetic markers, probes A156E1, PW71 and B25E9, critical regions involved in PWS and AS and imprinting centre (IC). 
Finally, Jalal et al..$^{15,16}$ used FISH to determine the content of duplicated proximal regions of chromosome 15 in normal persons and showed that single copies of D15S11 and GABRB3 were present. As the phenotype of patients with a chromosome 15q11q13 duplication is rather variable it might be reasonable to assume that, like in PWS

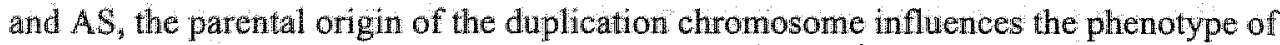
the patients. The patient described by Clayton-Smith et all ${ }^{8}$ has a maternally derived chromosome 15 duplication and similarities to AS, our patient has a paternally derived duplication and similarities to PWS. Several imprinted genes have been identified in chromosome region 15q11-q13: SNRPN (Glenn et al. ${ }^{26}$ ), IPW (Wevrick et al. ${ }^{27}$ ), ZFP 127 (Driscoll et al. ${ }^{28}$ ), and two anonymous transcripts (PAR-1 and PAR-5) (Sutcliffe et al. ${ }^{29}$ ). Altered dosage of (one of these) genes involved in PWS or modified gene products might be responsible for the specific subset of clinical features in our patient. This is also in agreement with previous observations in patients with triplication of 15 q11-q 13 studied with molecular techniques (Holowinsky et al. ${ }^{30}$, Schinzel et al. $\left.{ }^{31}\right)$. In these patients the increased dosage of genes in the PWS/AS critical region caused an abnormal phenotype, depending on the copy number and the parental origin. In conclusion, a proximal duplication in chromosome region 15q11-q13 was demonstrated with a region-specific paint and characterized further with locus-specific probes. In our opinion this duplication of sequences, frequently deleted in PWS and AS, causes the Prader-Willi like phenotype of the patient. Molecular analysis of the DNA methylation pattern disclosed no abnormality in this patient, indicating that chromosome analysis should always be applied in patients with clinical findings suggestive for PWS or AS. Furthermore, molecular analysis or FISH should be applied on patients with a proximal duplication in chromosome 15 to distinguish between a duplication of D15S10, D15S11, SNRPN or GABRB3 or a duplication or amplification of part of a region proximal of $15 q 12$ which seems a heritable and normal G-band polymorphism (Jalal et al. ${ }^{15,16}$ ). 


\section{References}

1- Nicholls RD. Invited editorial: New insights reveal complex mechanisms involved in genomic imprinting. Am J Hum Genet 54:733-740 (1.984).

2-Fuhrmann-Rieger $\mathrm{A}$, Kohler $\mathrm{A}$, Fuhrmann W. Duplication or insertion in 15q11-13 associated with mental retardation - short stature and obesity - Prader-Willi or Cohen symdrome? Clin Genet 25.347 352 (1984).

3- de France HF, Beemer FA, Ippel PF. Duplication in chromosome $15 q$ in a boy with the PraderWilli syndrome; further cytogenetic confusion. Clin Genet 26:379-382 (1984).

4- Berry $R$, McGavran L, Robinson J, Staley L. Familial duplication of proximall $1.5 q$ in Prader-Willi individual and her normal father. Am J Hum Genet 41:A114 (1987).

5- Pettigrew AL, Gollin SM, Greenberg F, Riccardi VM, Ledbetter D. Duplication of proximal $15 \mathrm{~g}$ as a cause of Prader-Willi syndrome. Am J Med Genet 28:791-802 (1987).

6- Rauch LA, Nevin NC. Duplication of 15q11.2-15q13 in five cases with different phenotypes. J Med Genet 28:573-574 (1991).

7- Li S, Tuck-Muller CM, Martinez JE, Yan Q, Rowley ER, Zhao Y, Werteleck W, Chen H. A boy with Prader-Willi syndrome due to familial transmission of duplication of chromosome $15(\mathrm{q} I 1-13)$. Am J Med Genet 62:206-207 (1996).

8- Clayton-Smith J, Webb T, Cheng XJ, Pembrey ME, Malcolm S. Duplication of chromosome 15 in the region 15q11-13 in a patient with developmental delay and ataxia with similarities to Angelman syndrome. J Med Genet 30:529-531 (1993).

9- Brookwell R, Veleba A. Proximal 15q variant with normal phenotype in three unrelated individuals. Clin Genet 31:311-314 (1987).

10-Turolla L, Baccichetti C, Artifoni L, Lenzini E, Leszl A, Tenconi R. A new family with extra material on proximal 15q. Ann Génét 32:230-232 (1989).

1)-Shohat M, Shohat T, Rimoun DL, Mohandas T, Heckenlively J, Magenis RE, Davidson MB, Korenberg JR. Rearrangement of chromosome 15 in the region $\mathrm{q} 11.2 \mathrm{q} 12$ in an individual with obesity syndrome and her normal mother. Am J Med Genet 37:173-177 (1990).

12-Ludowese CJ, Thompson KJ, Sekhon GS, Pauli RM. Absence of predictable phenotypic expression in proximal 15q duplications. Clin Genet 40:194-201 (1991).

13-Hirsch B, Heggie P, McConnell K. Inherited direct duplication of $15 q 11->15 q 13$ including loci

D15S11 > GABRB3 in a child with autism. Am J Hum Genet 57:646 (1995).

14-Crawford EC, Lethco BA, Bealer D, Schroer RJ, Clarkson KB, Phelan MC. Interstitial duplication and triplication of $15 \mathrm{q} 11-\mathrm{q} 13$ confirmed by fluorescence in situ hybridization. Am J Hum Genet 57:618 (1995).

15-Jalal SM, Persons DL, Dewald GW, Lindor NM. Form of $15 q$ proximal duplication appears to be a normal euchromatic wariant. Am J Med Genet 52:495-497 (1994).

16-Jalal SM, Spurbeck JL, Schad C, Lindor NM, Dewald GW. A form of duplication may be a normal euchromatic variant. Am J Med Genet 62:206 (1996).

17-Holm VA, Cassidy SB, Butler MG. Prader-Willi syndrome: consensus diagnostic criteria.

Pediatrics 91:398-402 (1993).

18-Dutrillaux B, Viegas-Pequignot E. High resolution R-and G-banding in the same preparation.

Hum Genet 57:91-93 (1988).

19-Engelen JJM, Albrechts ICM, Loots WJG, Hollanders-Crombach HTM, Hamers AJH, Geraedts JPM. Application of micro-FISH to delineate deletions. Cytogenet Cell Genet 75:167 1711 (1996). 20-Telenius H, Carter NP, Bebb CE, Nordenskjold M, Ponder BA, Tunnacliffe A. Degenerate oligonucleotide-primed PCR: general amplification of target DNA by a single degenerate primer. Genomics 13:718-725 (1992).

21-Guan XY, Cargille CB, Anzick SL, Thompson FH, Meltzer PS, Bittner ML, Taetle R, McGill JR, Trent JM. Chromosome microdissection identifies cryptic sites of DNA sequence amplification in human ovarian carcinoma. Cancer Res 55:3380-3385 (1995).

22-Kuwano A, Mutirangura A, Dittrich B, Buiting K, Horsthemke B, Saitoh S, Niikawa N, Ledbetter $\mathrm{SA}$, Greenberg F, Chinault $\mathrm{AC}$, Ledbetter DH. Molecular dissection of the Prader-Willi/Angelman 
syndrome region (15q11-13) by Yac cloning and FISH analysis. Hum Mol Genet 1/6:417-425 (1992). 23-Lichter $\mathrm{P}$, Cremer $T$, Borden $\mathrm{J}$, Manuelidis $\mathrm{L}$, Ward DC. Delineation of individual human chromosomes in metaphase and interphase cells by in situ suppression hybridization using recombinant DNA libraries. Hum Genet 88:224-234 (1988).

24-Dittrich $B$, Buiting $K$, Gross $S$, Horsthenke $B$. Characterization of a methylation imprint in the Prader-Willi syndrome chromosome region. Hum Molec Genet 2:1995-1999 (1993).

25-Buiting $K$, Saitoh $S_{3}$ Gross $\mathrm{S}$, Ditrich $\mathrm{B}$, Schwartz $\mathrm{S}$, Nicholls RD, Horsthemke B. Inherited microdeletions in the Angelman and Prader-Willi syndromes define an imprinting centre on human chromosome 15. Nature Genet 9:395-400 (1995).

26-Glenn CC, Saitoh $\$$, Jong MTC, Filbrandt MM, Surti U, Driscoll DI, Nicholls RD. Gene structure, DNA methylation and imprinted expression of the human SNRPN gene. Am J Hum Genet 58:335-

$346(1996)$.

27-Wevrick $\mathrm{R}$, Kerns JA, Francke U. Identification of a novel paternally expressed gene in the Prader-Willi syndrome region. Hum Molec Genet 3:1877-1882 (1994).

28-Driscoll DJ, Waters MF, Williams CA, Zori RT, Glenn CC Avidano KM, Nichols RD. A DNA methylation imprint, determined by the sex of the parent, distinguishes the Angelman and PraderWilli syndromes. Gienomics 13:917-924 (1992).

29-Sutcliffe JS, Nakao M, Christian S, Orstavick KH, Tommerup N, Ledbetter DH, Beaudet Al. Deletions of a differentially methylated $\mathrm{CPG}$-island at the SNRPN gene define a putative imprinting control region. Nat Genet 8:52-58 (1994).

30-Holowinsky S, Black SH, Howard-Peebles PN, Mutirangura A, Christian S, Ledbetter DH, Reynolds J: Triplication of 15q11-q13 in two unrelated patients with hypotonia, cognitive delays and visual impairment. Am J Hum Genet 53:A125 (1993).

31-Schinzel AA, Brecevic L, Bernasconi F, Binkert F, Berthet F, Wuilloud A, Robinson WP. Intrachromosomal triplication of 15q11-q13. J Med Genet 31:798-803 (1994).

32-Saitoh S, Buiting K, Rogan PK, Buxton JL, Driscoll DJ, Arnemann J, Konig R, Malcolm S, Horsthemke B. Minimal definition of the imprinting center and fixation of a chromosome 15q11-q l3 epigenotype by imprinting mutations. Proc Natl Acad Sci USA 93:781 1-7815 (1996). 
Chapter 8

GENERAL DISCUSSION AND CONCLUSIONS 
Microdissection, the technique to pick up chromosomal regions with a glass needle, was introduced some 15 years ago by Scalenge et al.'. It was used for the cloning in bacteria of genomic sequences from Drosophila salivary gland polytene chromosome bands. The introduction of the polymerase chain reaction (PCR) and sequence independent DNA amplification enabled Lildecke et al. ${ }^{2}$ to amplify dissected chromosomal material in vitro. Technical improvements allowed to reduce the number of dissected fragments from $>100$ (Bates et al. ${ }^{3}$ ) to approximately 25 and to use GTG-banded ehromosomes for microdissection (Senger et al. ${ }^{4}$ ). Meltzer et al. ${ }^{5}$ amplified microdissected chromosomal material using a degenerate oligonucleotide primedpolymerase chain reaction (DOP-PCR) and directly used the DOP-PCR product for reverse chromosome painting (micro-FISH).

In micro FISH, (microdissection combined with fluorescence in situ hybribization) four equally important steps can be distinguished. (1) The physical dissection of GTGbanded chromosomes or chromosome parts using a dissection needle or a laser beam. The dissection is followed by (2) treatment of the dissected chromosomal material with proteinase- $\mathrm{K}$, topoisomerase or heat to relax the supercoiled DNA of the metaphase chromosomes and (3) a degenerate oligonucleotide primed-polymerase chain reaction (DOP-PCR) to amplify the dissected DNA. Finally, (4) a reporter molecule (biotin or digoxigenin) is incorporated in the PCR product obtained and this PCR product is annealed to metaphase spreads from normal subjects to detect hybridization.

Micro-FISH is used in clinical cytogenetics to characterize chromosome aberrations like marker chromosomes, unbalanced chromosome translocations, complex chromosome rearrangements, deletions, duplications and inversions. As only five copies of a chromosome part have to be dissected to generate sufficient probe for an intense FISH signal, micro-FISH can also be used to analyse low grade mozaicisms. The whole process of microdissection, DOP-PCR, probe labeling and reverse painting can be completed within three days which makes this method perfectly suitable for prenatal diagnosis.

\section{Marker chromosome characterization.}

A marker chromosome (mar) is a structurally abnormal chromosome in which no part can be identified (ISCN $1995^{6}$ ). Mainly due to their small size and the lack of a distinct banding pattern marker chromosomes are often not identifiable by cytogenetic banding techniques. Constitutional markers are found with a frequency of $0.24 / 1000$ in lifeborn individuals (Buckton et al. ${ }^{7}$ ) and $0.4-1.5 / 1000$ at amniocentesis (Hook and Cross ${ }^{8}$, Sachs et al. ${ }^{9}$, Warburton et al. ${ }^{10}$ ). In mentally retarded patients the incidence of marker chromosomes is reported to be $3.27 / 1000$ (Buckton et al. ${ }^{7}$ ). Over $80 \%$ of the markers originate from the pericentromeric regions of the acrocentric chromosomes (Maraschio et $a{ }^{1}{ }^{11}$ ) and approximately $50 \%$ of these markers originate from the centromere region of chromosome 15 (Maraschio et al. ${ }^{11}$., Blennow et al. ${ }^{12}$ ). Beside conventional staining techniques, FISH, often preceded by chromosome flow sorting and microcloning or DOP-PCR of the chromosomal material, has been used to identify marker chromosomes (Rauch et al. ${ }^{13}$, Plattner et al. ${ }^{14}$, Blennow et al. ${ }^{12}$ and Crolla et al. ${ }^{15}$ ). 
The most straightforward approach for identification of marker chromosomes is, without any doubt, micro-FISH. The advantages of micro-FISH to identify marker chromosomes above the methods mentioned before are that it is less time consuming then the microcloning procedures and in comparison to chromosome sorting, the size of the marker is not a limiting factor. Furthermore, only a small number of dissected chromosomes is needed and at least up to three years old fixed cell suspensions can be used making retrospective analysis possible. Finally, marker identification with centromere probes or paints discloses the chromosomal origin of the marker but not the chromosome region involved.

\section{Analysis of complex chromosome rearrangements.}

Complex chromosome rearrangements (CCRs) have been defined as structural rearrangements involving at least two chromosomes and three or more chromosome breakpoints (Pai et al. ${ }^{16}$ ). CCRs may be balanced or unbalanced, familial or de novo. Since interpretation of a CCR is often difficult when only standard GTG-banding techniques are used, FISH with whole chromosome paints, developed by Pinkel et al. ${ }^{17}$ and Lichter et al.$^{18}$ is frequently used for characterization of a CCR. However, when a translocated region in a CCR is recognized due to its aberrant banding pattern, but complete characterization fails even with chromosome painting, then micro-FISH is the method of choice. Dissection of such a half-cryptic translocation followed by DOPPCR and reverse painting will disclose the region(s) of origin of the dissected chromosome part as well as enable a better delineation of the breakpoints.

\section{Deletion detection and breakpoint characterization.}

Another group of chromosome aberrations in which micro-FISH can be used for characterization are deletions. Chromosomes in which a part is deleted are, in general, easy to recognize. However, it can sometimes be difficult to determine the breakpoints in deletion chromosomes exactly, when the interpretation is based only on the banding pattern. Microdissection of the deletion chromosome followed by DOP-PCR amplification and painting of the patient's chromosomes, will provide information about the position of the deleted region. The deleted region will not display a FISH signal in the patient's normal chromosome. However, the deleted chromosome must display a FISH signal over its complete length as a prove that it is dissected and amplified completely. From recent work of Rubstov et al. ${ }^{19}$ and Stevens-Kroef et al. ${ }^{20}$ it became clear that deletions which look like terminal deletions with GTG-banding, are at least sometimes interstitial deletions. This finding will certainly lead to a re-interpretation of a number of terminal deletions. 


\section{Tumor cytogenetics}

In many human cancers the presence of marker chromosomes or unbalanced translocations prevents complete karyotypic analysis. For the assessment of chromosome rearrangements micro-FISH is becoming increasingly important. Only a few copies of the aberrant chromosomes need to be dissected and are sufficient for reverse painting. Indeed, the need for only a few copies offers an advantage ower previously described methods such as chromosome isolation by flow sorting (Telenius et al. ${ }^{21}$ ). Also in tumor cytogenetics, it is important to determine breakpoints precisely, because this creates the possibility to detect genes that play a role in tumor genesis. When chromosome quality is poor, as is true of many haematologic and solid tumors, deletions and breakpoints can be characterized more precisely through hybridization of the generated DOP-PCR probe to high resolution chromosomes of a control individual. Only very recently microdissection is used in conjunction with CGH (Liang et al. ${ }^{22}$ ), which in tumor cytogenetics will enable to obtain tumor cell populations without contaminating stromal cells. Identification of regions with sequence gain or loss with micro-FISH and CGH provides opportunities to identify genes that may be involved in tumor development and disease progression.

\section{Future perspectives}

In chapter 4 it was demonstrated that it is possible to detect a microdeletion of approximately $6 \times 10^{6}$ base pairs when using high-resolution chromosomes for reverse painting. As the length of the chromosomes used for reverse painting is the limiting factor for the detection of submicroscopic deletions, it is logical to presume that when using longer chromosomes for reverse painting even submicroscopic deletions can be detected. The use of prematurely condensed chromosomes might be a logical choice to resolve this problem. This approach will certainly be valuable in the search for submicroscopic deletions which might exist in patients with a de novo translocation when they present with dysmorphisms.

When isolating DNA from a breakpoint for subsequent cloning, a substantial part of the isolated clones will not be useful as they are located at a considerable distance of the breakpoint. To overcome this problem, chromosome stretching (Claussen et al. ${ }^{23}$ ) could be performed. With this technique it is possible to elongate chromosomes up to a resolution of 2000 bands or more per haploid autosome set. Consequently, after chromosome stretching followed by microdissection, it might be possible to construct a library of the dissected DNA that contains only clones of the breakpoint and close to the breakpoint.

Since the introduction of micro-FISH in 1992 a number of different methods have been developed to generate DOP-PCR probes (Guan et al. ${ }^{24}$, Yokoyama et al. ${ }^{25}$, MullerNavia et al. ${ }^{26}$, Engelen et al. ${ }^{27}$ ). For the analysis of chromosome aberrations these methods seem to be equally efficient. However, until now it is unclear whether all the microdissected chromosomal material is amplified completely and thus present in the DOP-PCR product. Information about the saturation of the DOP-PCR product is 
important when these probes are used for subsequent cloning. Reverse painting on DNA fibers (Parra and Windle ${ }^{28}$ ) might be useful in supplying information about the percentage of DNA that is really present after the DNA amplification. 


\section{References}

1-Sealenghe $\mathrm{R}_{\mathrm{j}}$ Turco $\mathrm{E}$, Edstrom JE, Pirrotta $\mathrm{V}$, Melli M: Microdissection and cloning of DNA from a specific region of Drosophila melanogaster polytene chromosomes. Chromosoma 84:205-216 (1981).

2-Ludecke HI, Senger $\mathrm{O}_{3}$ Claussen U, Horsthemke $\mathrm{B}$ : Cloning defined regions of the thuman genome by microdissection of banded chromosomes and enzymatic amplification. Nature 338: 348-350 (1989).

3- Bates $G \mathrm{P}$, Wainwricht $\mathrm{BJ}$, Williamson $\mathrm{R}_{7}$ Brown SDM: Microdissection of and microcloning from the short arm of human chromosome 2. Mol Cell Biol 6:3826-3830 (1986).

4. Senger $G_{3}$ Ludecke $\mathrm{HJ}$, Horsthemke $B$, Claussen $\mathrm{U}$ : Microdissection of banded human chromosomes. Hum Genet 84:507-511 (1990).

5-Meltzer PS, Guan XY, Burgess A, Trent J: Rapid generation of region specific probes by chromosome microdissection and their application. Nature Genet 1:24-28 (1992).

6- ISCN (1995): An International System for Human Cytogenetic Nomenclature, Mitelman F. (Ed);

S. Karger, Basel (1995).

7- Buckton KE, Spowart G, Newton MS, Evans HJ: Forty four probands with an additional "marker" chromosome. Hum Genet 69:353-370 (1985).

8. Hook EB, Cross PK: Extra structurally abnormal chromosomes (ESAC) detected in amniocentesis: frequency in approximately 75,000 prenatal cytogenetic diagnoses and association with maternal and paternal age. Am J Hum Genet 40:83-101 (1987).

9-Sachs ES, van Hemell JO, Den Hollander JC, Jahoda MGJ: Marker chromosomes in a series of 10000 prenatal diagnoses, Cytogenetic and follow-up studies. Prenat Diagn 7:81-89 (1987).

10-Warburton $\mathrm{D}$ : De novo balanced chromosome rearrangements and extra marker chromosomes identified at prenatal diagnosis. Am J Hum Genet 49:995-1013 (1991).

11-Maraschio $\mathbb{P}$, Cuoco $C$, Gimelli $G$, Zuffardi $O$, Tiepolo L: Origin and clinical significance of iny dup.(15). In: Daniel A, ed. The cytogenetics of mammalian autosomal rearrangements, New York:

Alan R. Liss, 615-634 (1988).

12- Blennow E, Brondum Nielsen K, Telenius $H_{3}$ Carter NP, Kristofferson U, Holmberg E, Gillberg C. Nordenskjold M: Fifty probands with extra structurally abnormal chromosomes characterized by fluorescence in situ hybridization. Am J Med Genet 55:85-94 (1995).

13-Rauch A, Pfeiffer RA, Trautman U, Liehr T, Rott HD, Ulmer R: A study of ten small supernumerary (marker) chromosomes identified by fluorescence in situ hybridization (FISH). Clin Genet 42:84$90(1992)$.

14-Plattner R, Heerema NA, Howard-Peebles PN, Miles JH, Soukop $\mathrm{S}_{\mathrm{s}}$ Palmer CG: Clinical findings in patients with marker chromosomes identified by fluorescence in situ hybridization. Hum Gienet $91: 589-598(1993)$.

15-Crolla JA, Harvey JF, Sitch FL, Dennis NR: Supernumerary marker 15 chromosomes: a clinical, molecular and FISH approach to diagnosis and prognosis. Hum Genet 95:161-170 (1995).

16-Pai GS, Thomas GH, Mahoney W, Migeon BR: Complex chromosome rearrangements. Clinic Genet 18:436-444 (1980).

17-Pinkel D, Straurne T, Gray JW: Cytogenetic analysis using quantitative, high sensitive fluorescence hybridization. Proc Natl Acad Sci USA 83:2934-2938 (1986).

18-Lichter P, Cremer T, Borden $\mathrm{J}_{3}$ Manuelidis $\mathrm{L}_{\mathrm{*}}$ Ward DC: Delineation of individual human chromosomes in metaphase and interphase cells by in situ suppression hybridization using recombinant DNA libraries. Hum Genet 88:224-234 (1988).

19-Rubtsov N, Senger $G$, Kuzcera H. Neumann $A_{n}$ Kelbova C, Junker K, Beensen V, Claussen U: Interstitial deletion of chromosome 6q: precise definition of the breakpoints by microdissection, DNA amplification, and reverse painting. Hum Genet 97:705-709 (1996).

20-Stevens-Kroef MJPL, Albrechts JCM, Dirks R, Loneus W, Bot F, Engelen JMM, Hamers AJH: Identification of a marker chronosome in a case of non-Hodgkin lymphoma by micro-FISH.

Cytogenet Cell Genet 77/1-2:p48 (1997).

21-Telenius H, Pelmear AH, Tunacliffe A, Carter NP, Behmel A, Ferguson-Smith MA, Nordenskjold 
M, Pfragner R, Ponder BAJ: Cytogenetic analysis by chromosone painting using DOP-PCR amplified flow-sorted chromosomes. Genes Chronosom Cancer 4257-263 (1992).

22-Liang BC, Meltzer PS, Guan XY, Trent JM: Gene amplification elucidated by oombined chromosomal microdissection and comparative genomic hylaridization. Cancer Genet Cytogenet $80: 55-59(1995)$.

23- Claussen U, Mazur A, Rubtsov N: Chromosones are highly elastic and can be stretehed. Cytogenet Cell Genet 66:120-125 (1994).

24- Guan XY, Trent JM, Meltzer PS: Generation of band-specific painting probes from a single microdissected chromosome. Hur Mol Genet 8:1117-1121 (1993).

25-Yokoyama $Y$, Sakuragawa N: Improved simple generation of GTG-band specific painting probes. Cytogenet Cell Genet 71:32-36 (1995).

26-Muller-Nawia J, Nebel A, Schleiermacher E: Complete and precise characterization of marker chromosomes by application of microdissection in prenatal diagnosis. Hum Genet 96:661 -667 (1995). 27- Engellen JJM, Albrechts JCM, Loots WJG, Hollanders-Crombach HTM, Hamers AJH, Geraedts JPM: Application of micro-FISH to delineate deletions. Cytogen Cell Genet 75:167-171 (1996).

28-Parta I, Windle B: High resolution visual mapping of stretched DNA by fluorescent hybridization. Nature Genet 5:17-21 (1993). 
Human cytogenetics is the discipline that is directed towards the study of human chromosomes at the microscopic level. During cell division the DNA present in the nucleus of the cell is packaged in chromosomes which can be individually identified. After treatment with trypsin and staining with Giemsa the chromosomes display a so called GTG-banding pattern. This technique allows to distinguish $350-550$ bands in a haploid set of chromosomes. The banding pattern is characteristic for each pair of chromosomes and thus allows the detection of aberrant chromosomes. Chromosome aberrations may be numerical (a number other than 46) or structural. In the group of structural aberrations that can be diagnosed, chromosomal material may be lost (deletion) or may be present twice (duplication). Furthermore, a part of a chromosome can be inverted within that chromosome (inversion) and chromosome parts can be exchanged between two or more chromosomes (translocation).

In the past 15 years fluorescence in situ hybridization (FISH) has become increasingly important in human cytogenetics. This technique can provide information about the presence and expression of specific DNA sequences in dividing and non-dividing cells. For FISH, a probe (a short DNA sequence) is labeled with a reporter molecule. This probe is hybridized with cellular DNA and binds with the complementary sequence within that DNA (hybridization). The hybridization site is visualized with a fluorescent molecule coupled with an antibody directed against the reporter molecule.

Despite GTG-banding and FISH there still exist chromosome aberrations that cannot be characterized completely. Micro-FISH is a technique that solves this problem. Microdissection combined with FISH (micro-FISH) comprises 4 different steps: (1) dissection of a (part of a) chromosome with microneedles, (2) amplification of the chromosomal material using the polymerase chain reaction (PCR), (3) labeling of the PCR product with a reporter molecule, and last (4) hybridization of the DNA on a normal metaphase and immunological detection. This procedure results in a fluorescent spot on the homologous chromosomes in the metaphase from which the dissected material originates.

In chapter 1, the development and the current status of micro-FISH, and its applications in molecular genetics and clinical cytogenetics are discussed. In chapter 2, a simple and efficient method for microdissection and DNA amplification is described. In chapter 3, micro-FISH was used to disclose the chromosomal origin of three marker chromosomes and the results were confirmed with chromosome painting. Chapter 4 reports on the application of micro-FISH to characterize a complex chromosome translocation. FISH with chromosome specific paints showed that at least four breakpoints were involved in this chromosome rearrangement, with micro-FISH a fifth breakpoint was detected which was characterized further with band-specific probes. Chapter 5 describes the application of micro-FISH for the detection of chromosomal deletions and the delineation of deletions in aberrant chromosomes. In chapter 6 the study of deletion detection was extended, a deleted region was characterized further with band-specific probes and the patient's phenotype is compared with other patients reported in the literature. Chapter 7 describes the application of a band-specific paint, generated by microdissection and subsequent DOP-PCR amplification, for the charac- 
terization of a intrachromosomal duplication. Furthermore the clinical picture of the patient was compared with other patients reported in the literature with a duplication of chromosome region $15 q 11-q 13$. Chapter 8 contains a general discussion with conclusions and future perspectives.

In clinical cytogenetics, micro-FISH is a suitable technique to characterize chromosome aberrations (marker chromosomes, unbalanced translocation, duplications); especially when GTG-banding alone offers no solution. Also, loss off chromosonal material can be visualized and breakpoints can be determined more precisely. As only a few copies of chromosome (part)s under study have to be available for microdissection, micro-FISH is also suitable when only few mitotic divisions are available as is frequently the case in tumor material. 
De humane cytogenetica houdt zich bezig met het onderzoek van chromosomen van de mens op microscopisch niveau. Tijdens de celdeling of mitose, is het DNA aanwezig in de vorm van individueel te onderscheiden chromosomen. Na behandeling met het enzym trypsine en kleuring met de kleurstof Giemsa vertonen chromosomen een z.g. GTG-banderingspatroon. Per haploide set chromosomen kunnen zo 350-550 banden van elkaar onderscheiden worden. Dit banderingspatroon is karakteristiek voor elk chromosoompaar en stelt ons in staat afwijkende chromosomen op te sporen.

Chromosomale afwijkingen kunnen numeriek zijn (dus meer of minder dan het normale aantal van 46) of structureel. Bij de structurele afwijkingen kan er sprake zijn van verlies van een deel van het chromosoom (deletie) of van verdubbeling van een chromosoomdeel (duplicatie). Verder kan een deel van het chromosoom omgekeerd binnen een chromosoom aanwezig zijn (inversie). Ook kunnen delen van chromosomen onderling uitgewisseld zijn (translocatie).

Gedurende de afgelopen 15 jaar is fluorescente in situ hybridisatie (FISH) een steeds belangrijkere rol gaan spelen in het chromosomen onderzoek van de mens. Deze techniek kan informatie verschaffen over het aanwezig zijn en de expressie van specifieke DNA sequenties in delende en niet-delende cellen. Bij FISH wordt een probe (een klein DNA deeltje) gemerkt met een reporter molekuul. Deze probe wordt gebracht op cellulair DNA waarbij de probe bindt aan de complementaire sequentie in dat DNA (hybridisatie). Vervolgens wordt een antilichaam (met daaraan gekoppeld een fluorescerende stof) gericht tegen het reporter molekuul gebruikt om de plaats van de probe op het DNA zichtbaar te maken. Met behulp van een fluorescentie microscoop is de lokalisatie van de probe op het cellulair DNA te zien als een fluorescerend signaal.

Ondanks de beschikbaarheid van deze technieken zijn er echter nog steeds chromosomale afwijkingen die niet (volledig) gekarakteriseerd kunnen worden. Hiervoor is de afgelopen jaren micro-FISH ontwikkeld. Microdissectie gecombineerd met fluorescente in situ hybridisatie (micro-FISH) is een techniek waarbij een viertal verschillende stappen zijn te onderscheiden: (1) dissectie van een (deel van een) chromosoom m.b.v. een zeer dunne glazen naald, (2) vermeerdering van het gedissecteerde chromosomale materiaal met behulp van de polymerase ketting reactie, (3) inbouwen van een reporter molekuul in dat chromosomaal DNA, en tenslotte (4) hybridisatie van het gesynthetiseerde DNA op een normale metafase en detectie. Het resultaat van deze procedure is dat er in de metafase een fluorescentie signaal zichtbaar is op het chromosoom waarvan het gedissecteerde materiaal afkomstig is. Als er dus een stukje chromosoom van onbekende herkomst wordt gedissecteerd kan men na micro-FISH aan de hand van het fluorescentie signaal op een of meer chromosomen in een metafase bepalen van welk chromosoom dit materiaal oorspronkelijk afkomstig was. In hoofdstuk 1 van dit proefschrift is de ontwikkelling van micro-FISH beschreven, alsmede de stand van zaken op dit moment. Verder wordt gerapporteerd over de toepassing van micro-FISH in moleculair genetisch en klinisch cytogenetisch onderzoek. In hoofdstuk 2 wordt een eenvoudige maar efficiente methode beschreven voor microdissectie en DNA amplificatie. In hoofdstuk 3 wordt micro-FISH gebruikt om de 
herkomst van een drietall marker chromosomen te bepalen, waarbij de onderzoeksresultaten zijn bevestigd met chromosoom-specifieke paints. In hoofdstuk 4 is de karakterisering van een complexe chromosoom translocatie beschreven. FISH met chromosoom-specifieke paints toonde aan clat bij deze chromosomale afwijking ten minste 4 breukpunten aanwezig waren; met micro-FISH werd een 5 de breukpunt aangetoond dat vervolgens met band-specifieke probes verder werd geanalyseerd. Hoofdstuk 5 beschrijft hoe met micro-FISH de positie van een deletie in een chromosoom en dus ook de breukpunten kunnen worden bepaald. Voorts werd aangetoond dat ook microdeleties zichtbaar kunnen worden gemaakt als de gegenereerde probe wordt gehybridiseerd op high-resolution chromosomen. In hoofdstuk 6 is een deletie die met micro-FISH werd aangetoond, met band specifieke probes nader in kaart gebracht. Dit gaf vervolgens de mogelijkheid de klinische kenmerken van het patiëntje in kwestie te vergelijken met in de literatuur beschreven patiënten. Een intrachromosomale duplicatie wordt in hoofdstuk 7 gekarakteriseerd, waarna een beschrijving volgt van andere patiënten uit de literatuur met een dergelijke duplicatie. Hoofdstuk 8 bevat een algemeen overzicht met conclusies en ontwikkelingen in de nabije toekomst. In de klinische cytogenetica is micro-FISH een geschikte techniek om chromosomale afwijkingen (marker chromosomen, ongebalanceerde translocaties, duplicaties) te karakteriseren, vooral als de klassieke GTG-bandering te kort schiet. Ook kan met deze techniek verlies van chromosomaal materiaal worden aangetoond en kunnen breukpunten nader worden bepaald. Het feit dat slechts een klein aantal afwijkende chromosomen beschikbaar hoeft te zijn voor microdissectie, maakt dat deze techniek ook bruikbaar is als er maar geringe hoeveelheden cellen beschikbaar zijn, hetgeen regelmatig het geval is bij materiaal afkomstig van tumoren. 
Aan een promotie onderzoek werken heel wat meer mensen dan alleen de promovendus en die mensen wil ik dan ook bij deze van harte bedanken.

Beste Joep, mijn promotor, bedankt voor het scheppen van de mogelijkheid om aan dit onderzoek te werken, voor je steun en je begeleiding in de afgelopen 5 jaar.

Beste Guus, je hebt me niet alleen het yak van cytogeneticus geleerd maar ook steeds mee-gedacht, -gedisscusieerd, -gewikt en gewogen. Hiervoor mijn welgemeende dank! Beste Bertien, Chris, Frank, Karien, Laurence, Melanie, Peter, Petra, Ruth, Wim en Wim; onderzoek en wetenschap is een schone zaak, maar de routine zorgt voor brood op de plank. Ik dank jullie voor de dagelijkse inzet, de betrokkenheid bij het werk en de gezellige sfeer waardoor het altijd prettig is met jullie samen te werken.

Jozefa Albrechts en Wil Loots bedank ik voor het verrichten van vele FISH experimenten en voor het ontwikkelen van DOP-PCR techniek.

Francis van der Lubbe en Jo Houben bedank ik voor hun uitstekende fotografische werk.

De leden wan de beoordelingscommissie dank ik voor het beoordelen van het manuscript.

Familie, vrienden, kennissen en collega's;

Bedankt allemaal voor jullie geduld; vanaf vandaag zal ik (proberen) beter bereikbaar en aanspreekbaar zijn.

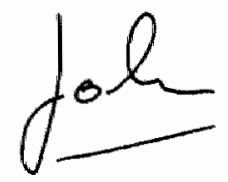


Johan Joseph Maria Engelen werd op 21 april 1953 geboren in de gemeente Nieuwenhagen. In 1971 behaalde hij het Atheneum-B diploma op het Bernardinus college te Heerlen.

Het kandidaatsexamen biologie werd behaald aan de Katholieke Universiteit Nijmegen in februari 1974, het doctoraalexamen in juni 1977. Afstudeervakken waren: Geobotanie (Prof. Dr. Westhof), Aquatisch Oecologie (Prof. Dr. den Hartog) en Medische Parasitologie (Prof. Dr. Meuwissen). Gedurende de studie werden student assistentschappen vervuld bij de afdelingen botanie en aquatische oecologie. Daarnaast werd de eerstegraads onderwijsbevoegdheid biologie gehaald. Na het afstuderen werkte hij enige maanden als leraar biologie bij het Collegium Marianum te Venlo.

In september 1978 begon hij met de studie Geneeskunde aan de Katholieke Universiteit Nijmegen. In augustus 1980 behaalde hij het kandidaatsexamen. Het Vrij doctoraal examen in deze studierichting werd behaald in oktober 1984 met als afstudeervakken Hematologie (Prof. Dr. Haanen), Epidemiologie (Prof. Dr. Sturmans) en Toxicologie (Prof. Dr. Henderson, Dr. Scheres). Van 16 juni 1982 tot 1 april 1984 was hij als wetenschappelijk medewerker verbonden aan het Instituut voor Antropogenetica van de Katholieke Universiteit te Nijmegen.

$\mathrm{Na}$ het afstuderen werkte hij voor NOTOX Safety \& Environmental Research B.V. in Den Bosch, was enige maanden werkzaam als leraar biologie aan het St. Maartens College te Maastricht en trad op 1 juni 1986 in dienst van de Rijksuniversiteit Limburg te Maastricht bij de capaciteitsgroep Arbeidsgeneeskunde. Sinds 1 augustus 1988 is hij als universitair docent werkzaam bij de vakgroep Moleculaire Celbiologie \& Genetica van de Rijksuniversiteit Maastricht en gedetacheerd bij de Stichting Klinische Genetica Limburg. 


\section{LIST OF PUBLICATIONS BY THE AUTHOR}

Borm PJM, Palmen N, Engelen JNM, Burman WA: Spontaneous and stimulated release of tumor necrosis factoralpha (TNF) from Blood monocytes of miners with coal workers' pneumoconiosis. Am Rev Respir Dis 138:1589-1594 (1988).

Borm PJM, Palmen N, Engelen JJM, Buurman WA: Oxidants, antioxidants and monokines in the pathogenesis of coal workers pneumoconiosis: Tumor necrosis factor as a mediator in lung fibrosis. In: Mossman BT, Begin RO (Eds), Effects of mineral dusts on cells. NATO ASI Series, Vol H30, Berlin, Springer-Verlag, 173-180 (1989).

Engelen JJM, Borm PJM, van Sprundel M, Leenaerts L: Blood anti-oxidant parameters at different stages of pneumoconiosis in coal workers. Environ Health Perspect 84:165-172 (1990).

van Faassen A, Engelen JJM, Falke HE, Hermus RJJ: Glutathion peroxidase activity as a biomarker of the selenium status of man. In: Kok FJ, van 't Veer P' (Eds), Biomarkers of dietary exposure. Proc. 3 rd meeting on mutritional epidemiology, London, Smith-Gordon and Company Limited, 113-114 (1991).

de Die-Smulders CEM, Engelen JJM, Donk JM, Fryns JP: Further evidence for the location of the BPES gene at $3 \mathrm{q} 2$. I Med Genet 28:725 (1991).

Engelen JJM, Hamers AJH, Schrander-Stumpel CTRM, Mulder $\mathrm{H}_{3}$ Poorthuis B: Assignment of the aspartylglucosaminidase gene (AGA) to $4 \mathrm{q} 33->4 \mathrm{q} 35$ based on decreased activity in a girl with a 46,XX,del(4)(q33) karyotype. Cytogen Cell Genet 60:208-209 (1992).

Janssen YMW, Engelen JJM, Giancola MS, Low RB, Vacek P, Borm PJM: Serum type III procollagen $\mathrm{N}$-terminal peptide in coal miners. Exp Lung Res 18:1-9 (1992).

Albering HJ "Hageman GJ, Kleinjans JCS, Engelen JJM, Koulischer L, Herens C: Indoor radon exposure and cytogenetic damage. The Lancet 340:739 (1992).

Evers LJM, Schrander-Stumpel CTRM, Engelen JJM, Mulder H, Borghgraef M, Fryns JP: Terminal deletion of long atm of chromosome 4: patient report and literature review. Genetic Counseling $4: 139-145(1993)$.

Veraart JCJM, Neuman HAM, Veraart CJTM, Engelen IJM: Ulcera crurum, gehyperpigmenteerde maculac en atrophie blanche als uiting van het syndroom wan Klinefelter. Ned Tijdschr Geneeskd. 13:8:86-89(1994).

Meijer H, de Graaff E, Merckx DML, Jongbloed RJE, de Di:-Smulders CEM, Engelen JJM, Fryns JP, Curf: PMG, Oostra $\mathrm{BA}$ : $A$ deletion of $1.6 \mathrm{~kb}$ proximal to the $\mathrm{CGG}$ repeat of the FMRI gene causes the clinical phenotype of the fragile X syndrome. Hum Molec Genet 3:615-620 (1994).

Schrander-Stumpel CTRM, Govaerts LCP, Engelen JJM, wan der Blij-Philipsen M, Borghgraef M, Loots WJG, Peters JJM, Rijnvos WPM, DFCM Smeets DFCM, Fryns JP: Mosaic tetrasony 8p in two patients: Clinical data and review of the literature. Am J Med Genet 50:377-380 (1994).

Engelen JJM, de Die-Smulders CEM, Fryns JP, Hoovers JMN, Albrechts JCM, Loots WJG, Jacobs ME, Hamers AJH: Partial trisomy and monosomy 8 p due to inversion duplication. Clin Genet 45:203207 (1994). 
Schrander-Stumpel CTRM, Gerver WJ, Meijer H, Engelen JM, Mulder H, Fryns JP: Prader-Willlike phenotype in fragile X syndrome. Clin Genet 45:175-180 (1994).

Veraart JCJM, Hamulyak $\mathrm{K}_{*}$ Neuman HAM, Engelen JJM: Increased plasma activity of plasminogen activator inhibitor 1 (PAI-1) in two patients with Klinefelter's syndrome complioated by leg ulcers. $\mathrm{Br}$ Dermatol 130:641-644 (1994).

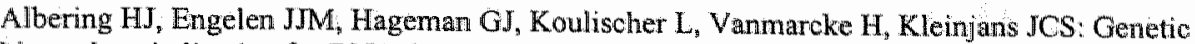
biomarkers indicative for DNA damage in relation to indoor radon exposure. Arm Ass Belge Radioprot 19:15-26 (1994).

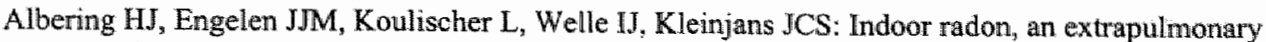
genetic risk. The Lancet 344:750-751 (1994).

Moog U, Engelen JJM, de Die-Smulders CEM, Albrechts JCM, Loneus WH, Haagen AAM, Raven EJM, Hamers AJH: Partial trisomy of the short arm of chromsome 18 due to inversion duplication and direct duplication. Clin Genet 46:423-429 (1994).

Ibbotson SH, Layton AM, Davies JA, Goodfield MJD, Veraart JCJM, Hamulyak K, Neuman HAM, Engelen JJM: Plasminogen activator inhibitor 1 (PAI-1) levels in patients with chronic venous leg ulceration. Br J Dermatol 131:738-739 (1994).

Plomp AS, Schrander-Stumpe] CTRM, Engelen JJM, Sijstermans JMJ, Loneus WH, Fryns JP: Interstitial deletion of the short arm of chromosome 8: report of a patient and review of the literature. Genetic Counseling 6:55-60 (1995).

Schrander-Stumpel CTRM, Gerver WJ, Meijer H, Engelen JJM, Mulder H, Fryns JP: Prader-Willilike phenotype in fragile X syndrome. In: Kersten MCO (ed), Wetenschappelijk onderzoek ten behoeve van de zorg aan verstandelijk gehandicapten. BBI, Utrecht, 92 (1995).

Engelen JJM, de Die-Smulders CEM, Sijstermans JMJ, Meers LEC, Albrechts JCM, Hamers AJH: Familial partial trisomy $8 \mathrm{p}$ without dysmorphic features and only mild mental retardation. Clin Genet 32:792-795 (1995).

de Die-Smulders CEM, Engelen IJM, Schrander-Stumpel CTRM, Govearts LCP, de Vries B, Vles JSH, Wagemans A, Schijns-Fleuren S, Gillissen-Kaesbach G, Fryns JP" Inversion duplication of the short arm of chromsome 8: Clinical data on seven patients and review of the literature. Am J Med Genet 59:369-374 (1995).

Engelen JJM, Loots WJG, Motoh PCC, Moog U, Hamers AJH, Geraedts JPM: Marker chronosome identification by micro-FISH. Clin Genet 49:242-248 (1996).

Engelen JJM, Loots WJG, Albrechts JCM, Motoh PCC, Fryns JP, Hamers AJH, Geraedts JPM: Disclosure of five breakpoints in a complex chromosome rearrangement by microdissection and FISH. J Med Genet 33:562-566(1996).

Frints SGM, Schrander-Stumpel CTRM, Engelen JJM, Da Costa AJ, Firyns JP: Partial trisomy and partial monosomy of the distal long arm of chromosome 4: patient report and literature review. Genetic Counseling 7:135-142 (1996).

Moog U, Engelen JJM, Albrechts JCM, Hoorntje TM, Hendrikse F, Schrander-Stumpel CTRM: Alagille syndrome in a family with duplication 20p11. Clin Dysmorphol 5:279-288 (1996).

Evers LJM, Schrander-Stumpel CTRM, Engelen JJM, Hoorntje TM, Pulles-Heintzberger CFM, 
Schrander JIP, Albreotits JCM, Peters I; Fryms JP: Deletion of the long arm of chromosome 6: 2 new patents and literature review. Clin Genet 50:138-144 (1996).

de Die-Smulders CEM, Engelen JM: 11q Duplication in a patient with Pitt-Rogers-Danks phenotype. Am I Med Genet 66:116-117 (1996).

Engelen JJM, Albrechts JCM, Loots WJG, Hollanders-Crombach HTM, Hamers AJH, Geraedts JPM: Application of micro-FISH to delineate deletions. Cytogen Cell Genet 75:167-171 (1996).

van de Graaf G, Sijstermans JMJ, Engelen JJM, Schrander-Stumpel CTRM: Mild phenotype in interstitial $4 p$ deletion: another patient and review of the literature. Genetic Counseling 8 :

$13.18(1997)$.

Chandley KE, Schrander-Stumpel CTRM, Engelen JMM, Theunissen P. Fryns JP: Partial trisomy 15q: Report of a patient and literature review. Genetic Counseling 8:91-97 (1997).

Engelen JMM, Detera-Wadleigh S, Albrechts JCM, van Eys G: Assignment of the human gene for Smoothelin to chromosome region $22 q 12$ by fluorescence in situ hybridization. Genomics $42: 245-247$ (1997).

Chandley KE, de Die-Smulders CEM, Engelen JMM, Schrander JJP: Severe feeding problems and congenital laryngostenosis in a patient with $3 q 23$ deletion. Eur J Pediatr 156:636-638 (1997).

Engelen JJM, Plomp AS, Albrechts JCM, van der Meer SB, Loots WJG, Vles JSH, Hamers AJH, Geraedts JPM: Characterization of a de novo unbalanced translocation (14q18q) using micro-FISH. Am Med Genet, in press.

Geraedts JPM, Engelen JJM: Cytogenetica. In: Pronk JC, Beemer FA, Geraedts JPM, Leschot NJ, Liebaerts I (Eds), Medische Genetica, 6e editie, Elsevier/Bunge, Amsterdam, In press.

Plomp $\mathrm{AS}_{\text {th }}$ Engelen JJM, Albrechts JCM, de Die-Smulders CEM, Hamers AJH: Two cases of partial trisomy $8 \mathrm{p}$ and monosomy $21 \mathrm{q}$ in a family with a reciprocal translocation $(8 ; 21)(\mathrm{p} 21.1 ; \mathrm{q} 22.3)$. J Med Genet. In press.

Engelen JJM, Albrechts JCM, Hamers AJH, Geraedts JPM: A simple and efficient method for microdissection and FISEI. J Med Genet. In press.

Engelen JIM, Loots WJG, Albrechts JCM, Schrander-Stumpel CTRM, Dirckx R, Hamers AJH, Geraedts JPM: Duplication of chromosome region $15 \mathrm{q} 11-15 \mathrm{q} 13$ in a patient with similarities to Prader-Willi syndrome confurmed by region specific painting and FISH. Submitted for publication.

Zwingmann IH, Welle IJ, Herwijnen M van, Engelen JM, Schildermann PAEL, Smid T, Kleinjans JCS: Oxidative DNA damage and eytogenetic effects in flight engineers exposed to extraterrestrial radiation. Submitted for publication.

Zwingmann IH, Welle IJ, Herwijnen M van, Engelen JJM, Schildermann PAEL, Jong JMA de, Kleinjans JCS: Oxidative DNA damage and cytogenetic effects in cancer patients induced by radiotherapy. Submitted for publication.

Frunts SGM, Schrander-Stumpel CTRM, Schoenmakers EFPM, Engelen JJM, Reekers ABA, wan den Neucker AM, Smeets E, Devlieger H and Fryns JP: Strong variable clinical presentation in 3 patients with $7 \mathrm{q}$ terminal deletion. Submitted for publication. 
Frints SGM, Engelen JMM, Arets HGM, Maat-Kievit JA, Vandeviver N, Schrander-Stumpel CTRM: Upper limb postaxial polydactyly in patients with 22 q 11 chromosomal deletion. Submitted for publication. 
Engelen JJM, Meijers JMM, Borm PJM: Blood anti-oxidant parameters in Coal Workers' Pneumoconiosis. 7th International congress on Pneumoconiosis, Pittsburgh, USA (1988).

Bom PJA. Frigelen JJM, Palmen N and Butrman WA: Red blood cell anti-oxidants and monocytes" Tumor Necrosis Factor in the pathogenesis of Coal Workers Pneumoconosis. 2nd GERP Conference on Lung Diseases, Paris, France (1989).

de Die-Smulders CEM, Donk JM, Engelen JJM, Fryns JP: BPES and translocation ( $3 ; 11)(\mathrm{q} 21 ; \mathrm{q} 23)$ in father and son. Chin Genet 40:377 (1991).

de Dia-Smulders CEM, Schrander-Stumpel CTRM, Engelen JMM, Govaerts LCP, de Vries B, Vles HSH, Wagemans A, Schijns-Fleuren S, Fryms JP: Duplication of the short arm of chromosome 8: A clinical recognizable syndrome. Genetic Counseling 5:102 (1994).

Moog U, Engelen J.M, Albrechts JCM, Hoorntje TM, Schrander-Stumpel CTRM: Alagille syndrome in a family with duplication 20p11. Med Genetik 2:207-208 (1995).

Gillissen-Kaesbach $G$, Albrecht B, Engelen JJM: Cytogenetic and molecular detection of a $4 p$ deletion in 4 patients with Wolf-Hirschhorn syndrome. Med Genetik 2:228 (1995).

Loneus WH, Albrechts JCM, Meers LEC, Engelen JMM, Hamers AJH: The use of FISH to interpret a complex chromosomal rearrangement involving 4 chromosomes. Applied Cytogenetics 22:84 (1996).

Albrechts JCM, Loots WJG, Hamers AJH, Engelen JJM: Analysis of a complex chromosome rearrangement by microdissection and FISH. Applied Cytogenetics 22:86 (1996).

Moog U, Coonen E, Dumoulin JCM, Engelen JJM: Karyotypes of men involved in ICSI programmes: the Maastricht experience april 1994 up to date. Human Reproduction 11(A1):233 (1996).

van der Loop F, Timmer E, Engelen JJM, van Straaten H, Ramaekers F, van Eys G: Smoothelin: A structural component in smooth muscle cells. Molecular mechanisms of myofibrill assembly, Chiba (1996).

Schrander-Stumpel CTRM, Gillessen-Kaesbach $G_{n}$ Engelen JJM, Albrecht B, Ippel E, Knol I, Beener F, Colla-Pijkels E, Fryns JP: Pallister-Killian syndrome: A challenging diagnosis. In: Blackburn W, Phelan MC (Eds), The proceedings of the Greenwood genetic center 16:139 (1997).

de Die-Smulders CEM, Engelen JJM, Tuerlings J, Vles JSH, Moog U, Fryns JP: Clinical features in patients with duplications of chromosome 18. Genetic Counseling 8:68-69 (1997).

Schrander-Stumpel CTRM, Engelen JM, Albrechts JCM, Loots WJG, Vles JSH, da Costa AJ, Fryns JP: Chromosome 15: there is more than Prader-Willi and Angelman syndrome. Genetic Counseling $8: 70(1997)$.

Eingelen JJM, Albrechts JCM, de Die-Smulders CEM: Marker chromosome identification using micro-FLSH. Med Genetik 9:66 (1997).

Stevens-Kroef MJPL, Albrechts JCM, Dirks R, Loneus W, Bot F, Engelen JJM, Hamers AJH: ldentification of a marker chromosome in a case of non-Hodgkin lymphoma by micro-FISH. Cytogenet Cell Genet 77:P48 (1997). 
Giltay JC, Kastrop PMM, Pearson PL, Scheres JMC, Engelen JJM, Bernards J, Bots RSGM: Nomal healthy child after ICSI in a male with a de novo $(\mathrm{Y} ; 16)$ translocation. 10th World congress on in vitro fertilization and assisted reproduction.. Vancouver, B.C., Camada, 1997.

de Die-Smulders CEM, Schrander IPP, Janssen K, Vandevijver N, Joenje H, Engelen JJM: Fanconi anemia syndrome: a very variable spectrum of anomalies. Genetic Counseling; in press.

Frints SGM, Schrander-Stumpel CTRM, Schoenmakers EFPM, Engelen JJM, Reekers ABA, Smeets E, Devlieger H, Frijns JP: Variabel clinical presentation in 3 patients with a $7 \mathrm{q}$ terminal deletion. Genetic Counseling, in press. 